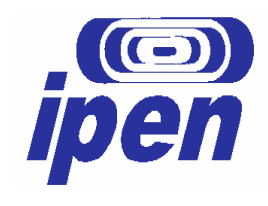

INSTITUTO DE PESQUISAS ENERGÉTICAS E NUCLEARES

Autarquia associada à Universidade de São Paulo

\title{
ASPECTOS DA RESISTÊNCIA À INFECÇÃO EXPERIMENTAL COM \\ Trypanosoma cruzi
}

VIVIANE LIOTTI DIAS

Dissertação apresentada como parte dos requisitos para obtenção do Grau de Mestre em Ciências na Área de Tecnologia Nuclear - Aplicações

Orientador:

Prof. Dr. Luiz Augusto Corrêa Passos

São Paulo 
Dedico este trabalho aos meus queridos filho, marido, pais, irmãos, sobrinhos e amigos, que de tão especiais, foram sempre inspiração! 


\section{AGRADECIMENTOS}

Agradeço primeiramente ao meu orientador e amigo Prof. Dr. Luiz Augusto Corrêa Passos, pelos ensinamentos e por todo o carinho e dedicação nestes anos de convivência, e a quem devo quase tudo o que aprendi no trabalho dentro do CEMIB. Muito obrigada!

À querida Dra. Nanci Nascimento, pela parceria IPEN/CEMIB e que desde o início do meu programa de pós-graduação, sempre me orientou em todos os processos, com extrema dedicação e atenção. Muitíssimo obrigada por tudo!

Ao Dr. Patrick Spencer, por todas as dicas essencialmente importantes durante o meu seminário de área e outras tantas que me foram muito úteis.

Aos meus queridos amigos e companheiros do dia a dia no Laboratório de Genética:

Ana Paula, amigona pra todas as horas. Sempre pronta a ajudar. Entramos juntas no CEMIB. Já fazem 15 anos!

Andréia, companheira de viagem pra São Paulo, nas disciplinas do IPEN. Quantas vezes hein? Que batalha! Mas conseguimos e vencemos!!!

Rodrigo, como todo bom sagitariano...Temos muito em comum. Conte comigo sempre!!!

Marcus e Marcelo, mentes brilhantes! Estou aprendendo a cada dia com vocês!

Dani, você chegou no laboratório e já faz parte dele. Fique sempre conosco!

Às Jéssicas, vocês me ajudam muito, obrigada! 
Aos colegas do CEMIB:

À Dra. Delma, e Armando, nossos diretores, pelo apoio e incentivo na realização deste trabalho.

Marcos Zanfolin, pela atenção, dedicação e companheirismo.

Cris, Érika, Regina, Alda, Antônio, Robson, Euma, Rodnei, Paulinho, Rafael, que me atendem prontamente quanto aos animais e insumos para o trabalho.

Ao pessoal do Laboratório de Controle Sanitário: Sílvio, Josélia, Clarice, Danielli e Lenira pela atenção e paciência.

Ao Dr. Rovilson, por ceder espaço em seu laboratório para manutenção e procedimentos com os animais de cultura in vivo de T. cruzi. Obrigada!

Aos colegas da secretaria: Sérgio, Márcio, Marisa, Elaine e Catarina, pela paciência com a turma do lab.

Dra. Ana Maria Guaraldo, por toda sabedoria, orientação e carinho de sempre.

Aos colegas da manuteção: Armando, Zé, Babu e Roberto. Sempre alertas!

A todos os colegas do CEMIB que direta ou indiretamente contribuíram para a realização deste trabalho ou simplesmente pela agradável convivência de todos os dias.

Aos colegas que passaram pelo CEMIB e que deixaram saudades.

Aos colegas de outros departamentos da UNICAMP, que me ajudaram muito nos primeiros anos do trabalho como o Marquinhos, a Dirce, Seo Antônio, a Cristina, a Dra. Wirla e Dra. Liana, todos da Micro-Imuno. 
Aos professores das disciplinas do IPEN, que me proporcionaram novos e surpreendentes conhecimentos.

Aos colegas que fiz durante o cumprimento dos créditos no IPEN.

À Roseli, minha psicóloga e Euzanir, minha professora de yoga, que muito me ajudaram a entender e superar as dificuldades enfrentadas, orientando-me a agir com sabedoria e a manter mente e corpo equilibrados.

Aos meus familiares e amigos, que sempre souberam entender minhas mancadas nos encontros! "É que eu tinha que escrever ou estudar pra tese!!!!....."

Aos doentes de Chagas, que tanto sofrem pela negligência com que esta doença ainda é tratada.

A todos os animais utilizados neste trabalho, os quais desempenharam o papel mais importante e para os quais tenho o maior respeito!

Finalmente agradeço a Deus, pela minha saúde e da minha família!

Obrigada! 
"A chave de todas as ciências é inegavelmente o ponto de interrogação" Honoré de Balzac 


\title{
ASPECTOS DA RESISTÊNCIA À INFECÇÃO EXPERIMENTAL COM Trypanosoma cruzi
}

\author{
Viviane Liotti Dias
}

RESUMO

A doença de Chagas, zoonose causada pelo protozoário Trypanosoma cruzi, apresenta uma ampla distribuição na América Latina estendendo-se do Sul dos Estados Unidos até a Argentina. Estima-se existirem 10 milhões de pessoas infectadas e outras 25 milhões expostas ao risco. Apesar de descoberta há mais de um século, o mal de Chagas ainda é uma infecção grave que provoca grande impacto sócio-econômico, sem tratamento efetivo na fase crônica e que carece de conhecimentos científicos. O presente trabalho teve como objetivo a obtenção e o uso de linhagens consômicas de camundongos, na investigação da resistência. As linhagens consômicas foram produzidas por meio de acasalamentos programados e monitoração com marcadores polimórficos de DNA, onde um de seus cromossomos foi substituído pelo seu homólogo da outra linhagem. Como parentais foram utilizadas as linhagens isogênicas C57BL/6/J Unib, de fenótipo resistente (doadora) e A/JUnib, susceptível (receptora) empregadas na produção de cinco linhagens consômicas para os cromossomos 7 (CSs7), 11 (CSs11), 14 (CSs14),17 (CSs17) e 19 (CSs19); descritos por Passos et al. (2003), como importantes no controle da infecção causada pela cepa $Y$ do T.cruzi. Nos ensaios experimentais, os consômicos foram inoculados pela via i.p., com as doses de $10^{1}, 10^{2}, 10^{3}$ e $10^{4}$ empregando-se como controles animais de ambas as linhagens parentais. Em todos os consômicos, a resistência foi superior àquela observada no parental susceptível. Em um segundo protocolo, os consômicos foram acasalados com associações programadas $\mathrm{e}$ as progênies foram desafiadas empregando-se inóculos com doses crescentes de tripomastigotas. A resistência observada neste grupo foi também superior àquela observada no parental de fenótipo susceptível. Os resultados observados demonstram que o emprego das linhagens consômicas produzidas possibilitam avaliar a participação de cada cromossomo na resistência, bem como os efeitos da associação entre os 
cromossomos, que são uma estratégia eficiente no estudo de doenças multifatoriais de trato complexo, como a doença de Chagas.

Palavras chave: doença de chagas, linhagens consômicas, genética da resistência, camundongos, Trypanosoma cruzi. 


\title{
ASPECTS OF RESISTANCE TO EXPERIMENTAL INFECTION WITH Trypanosoma cruzi
}

\author{
Viviane Liotti Dias
}

\begin{abstract}
Chagas disease, a zoonosis caused by the protozoan Trypanosoma cruzi, has a wide distribution in Latin America and extends from the southern part of the United States to Argentina. A number of 10 million of infected people is estimated and another 25 million exposed to the risk. Although discovered over a century, Chagas disease is still a serious infection that causes great socioeconomic impact, with no effective treatment at the chronic phase and in which, a lack of scientific knowledge can be observed. The main goal of this work was that obtaining and using consomic strain of mice, the resistance could be investigated. Consomic strains were produced by programmed mating, in which the animals were monitored with DNA polymorphic markers, and one of his chromosomes was replaced by his homologue from another strain. As parental, were used, the inbred strains C57BL/6/J Unib with resistant phenotype (donor) and as receiver, the A/JUnib strain, that has a susceptible phenotype. These models were used to produce five consomic strains: for the chromosomes 7 (CSs7), 11 (CSs11), 14 (CSs14), 17 (CSs17) and 19 (CSs19), described by Passos et al. (2003) as important in controlling infection caused by the $\mathrm{Y}$ strain of $T$. cruzi. In experimental testing, the consomics were inoculated intraperitoneally at doses of $10^{1}, 10^{2}, 10^{3}$ and $10^{4}$ using as control, animals from both parental lines. In all consomics, resistance was higher than that observed in the susceptible parental. In a second protocol, the consomics were mated with scheduled associations and the progenies were challenged with inocula employing increasing doses of trypomastigotes. The resistance observed in this group was also higher than that observed in the parental with susceptible phenotype. The observed results demonstrate that the use of the consomic strains that were produced order to assess the contribution of each chromosome in the resistance, as well as the effects of association between chromosomes are an effective strategy in the study of complex multifactorial diseases tract, such as Chagas disease.
\end{abstract}


Keywords: Chagas disease, consomic strains, genetics of resistance, mice, Trypanosoma cruzi. 


\section{SUMÁRIO}

\section{RESUMO}

ABSTRACT

1. INTRODUÇÃO -- 2

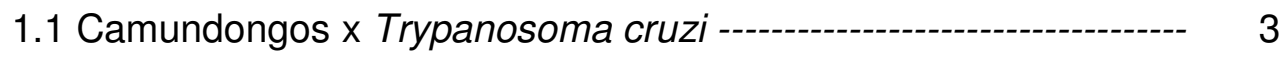

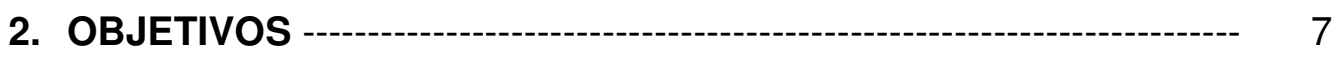

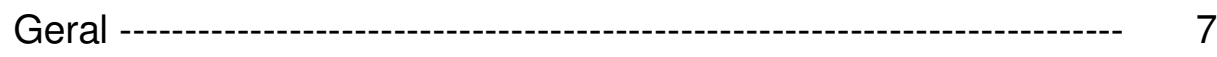

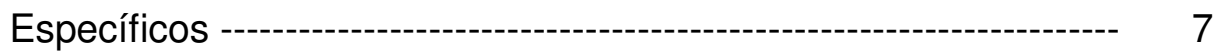

3. REVISÃO DA BIBLIOGRAFIA --

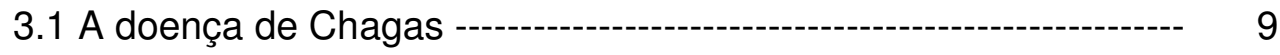

3.1.1 História ---

3.1.2 Epidemiologia e distribuição geográfica ------------------ 9

3.1.3 Iniciativas governamentais no combate à doença ----------- 10

3.1.4 O agente Trypanosoma cruzi e o seu ciclo de vida --------- 12

3.1.5 Formas de transmissão da doença -------------------- 14

3.1.5.1 Transmissão vetorial -------- 14

3.1.5.2 Transmissão transfusional -------------------------- 14

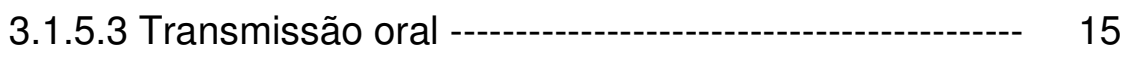

3.1.5.4 Transmissão congênita ou vertical ----------------- 15

3.1.5.5 Transmissão pelo leite materno -------------------- 16

3.1.5.6 Transmissão por acidentes de laboratório ---------- 16

3.1.5.7 Transmissão por transplante de órgãos ------------ 17

3.1.6 Apresentação clínica da doença: sinais e sintomas -------- 17

3.1.6.1 Doença de Chagas aguda (DCA) -------------- 17

3.1.6.2 Doença crônica ---

3.1.6.2.1 Fase crônica indeterminada ------------- 17

3.1.6.2.2 Fase crônica cardíaca e digestiva --------- 18

3.1.7 Diagnóstico ---------------------------------------------------- 18

3.1.8 Tratamento --

3.1.9 Estudos de drogas e vacinas contra a doença de Chagas - 19

3.2 Modelo animal e a ciência de animais de laboratório ------------ 20

3.2.1 Modelo animal: escolha e importância para os resultados experimentais 
3.2.2 Camundongos utilizados na pesquisa biomédica ---------- $\quad 20$

3.2.2.1 Linhagens isogênicas ---------------------- 21

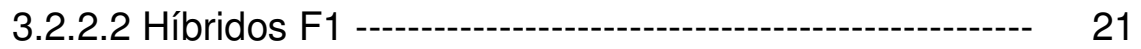

3.2.2.3 Híbridos ou recombinantes F2 ---

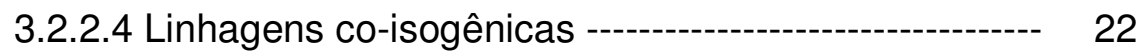

3.2.2.5 Linhagens congênicas------------------------------- 22

3.2.2.6 Linhagens recombinantes congênicas----------------- 22

3.2.2.7 Linhagens consômicas ----------------------------- 23

3.2.2.8 Linhagens recombinantes consômicas---------------- 23

3.2.3 Características das linhagens isogênicas de camundongos utilizadas no presente trabalho ----------------------------- 24

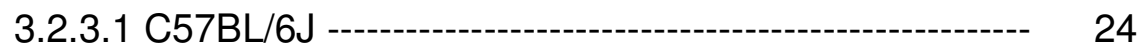

3.2.3.2 A/J ----------------------------------------------------------- 25

3.2.3.3 CBA/J -------- 25

3.2.4 A ciência de animais de laboratório --------------------- 26

3.3 Genética da resistência -------- 28

3.4 Resposta imune experimental x resistência ao T. cruzi ---------- 32

4. MATERIAL E MÉTODOS -- 36

4.1 Material -------------------------------------------------- 36

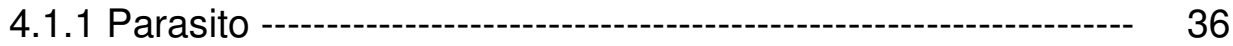

4.1.2 Animais ---

4.1.3 Reagentes ----------------------------------------------------- 36

4.2 Métodos --- 36

4.2.1 Manutenção dos animais ------------------------------- 36

4.2.2 Certificação genética das linhagens parentais com marcadores moleculares de DNA (polimorfismo de

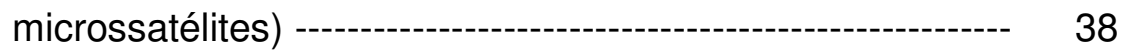

4.2.2.1 Extração das amostras de DNA por precipitação alcoólica ------o--o 39

4.3 Produção dos animais recombinantes F2 --------------- 39

4.3.1 Genotipagem dos animais F2 para seleção dos cromossomos

4.3.2 Acasalamentos programados para a produção das 
linhagens consômicas

4.3.3 Acasalamentos dos animais consômicos para expansão e infecção

4.3.4 Produção das linhagens recombinantes consômicas de primeira geração pelo cruzamento entre consômicos

4.3.5 Formação dos estoques para infecção 43

4.3.6 Preparação dos grupos experimentais 44

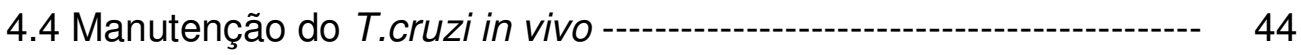

4.4.1 T.cruzi sangüícolas para os testes de infecção 44

4.5 Determinação das doses discriminatórias e infecção das linhagens parentais C57BL/6/Unib, de fenótipo resistente e A/JUnib, susceptível: grupos controle da infecção ------------------ 44

4.5.1 Análise da parasitemia -------------------------------- 45

4.5.2 Acompanhamento da sobrevivência ou mortalidade ---------- 45

4.6 Registro das colônias: controle e acompanhamento das

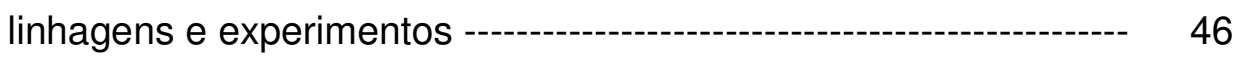

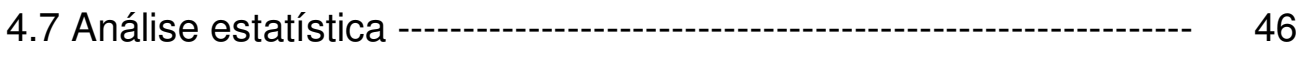

5. RESULTADOS

5.1 Certificação genética das linhagens parentais com o uso de marcadores moleculares polimórficos de microssatélites empregando a reação da PCR

5.2 Seleção e acasalamentos programados para produção das linhagens consômicas

5.3 Infecção das linhagens parentais de fenótipos resistente e susceptível com T. cruzi: grupos controle da infecção-

5.3.1 Infecção dos animais consômicos com o parasito nas doses de $10^{1}$ a $10^{4} / \mathrm{mL}$

5.3.2 Comparação da sobrevivência dos consômicos com os parentais resistente e susceptível

5.4 Seleção e acasalamentos programados para produção de animais recombinantes originados de cruzamentos entre consômicos em primeira geração

5.4.1 Comparação da sobrevivência entre os filhos de primeira 
geração dos consômicos com os parentais e fenótipo resistente e susceptível -------------------------------------- 54

5.5 Análise da parasitemia -------- 55

5.6 Períodos de mortalidade --

5.7 Animais resistentes ---

6. DISCUSSÃO - - 65

7. CONCLUSÕES - -

8. REFERÊNCIAS BIBLIOGRÁFICAS --- 78

9. ANEXOS--

Anexo 1. Certificado da Comissão de Ética no uso de animais-------- 91

Anexo 2. Extração de DNA----------- 92

Anexo 3. PCR (Reação em Cadeia da Polimerase)-------------------- 93

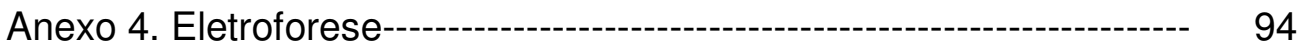




\section{LISTA DE TABELAS}

Tabela 1: Avaliação genética das linhagens parentais isogênicas C57BL/6/Unib, A/JUnib, e da linhagem CBA/JUnib (manutenção in vivo de T. cruzi). Marcadores de microssatélites polimórficos (primers) utilizados: D6mit254 (cromossomo 6), D7mit31 e D7mit301 (cromossomo 7), D14mit165 (cromossomo 14), D15mit246 (cromossomo 15), D17mit88 e D17mit176 (cromossomo 17) e D19mit19 (cromossomo 19)--------------

Tabela 2: Marcadores de microssatélites polimórficos entre as linhagens isogênicas parentais C57BL/6/Unib (resistente) e A/JUnib (susceptível) usados na selecão por PCR (genotipagem), dos F2 para a obtenção das linhagens consômicas

Tabela 3: Início do período de observação da parasitemia, segundo a dose de infecção. Para $10^{1}$ tripomastigotas, contagem no $15^{\circ}$ dia após-infecção; $10^{2}, 12^{\circ}$ dai; $10^{3}, 10^{\circ}$ dai e $10^{4}, 7^{\circ}$ dai,

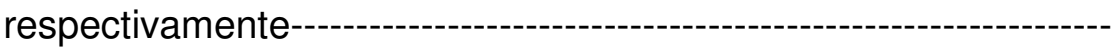

Tabela 4: Resultados da seleção por PCR de machos e fêmeas, descendentes da 6⿳亠丷. geração de intercross, para os acasalamentos em expansão da linhagem CSs17

Tabela 5: Padrão de resistência observado com as linhagens parentais C57BL/6/Unib e A/JUnib, após a inoculação de diferentes doses $\left(10^{1}\right.$ a $\left.10^{5}\right)$ de tripomastigotas

Tabela 6: Resultados da comparação entre machos e fêmeas das linhagens consômicas após infecção com as doses de $10^{1}$ a $10^{4}$ tripomastigotas de T. Cruzi-

Tabela 7: Resultados dos comparativos na sobrevivência observada entre as linhagens consômicas que apresentaram resistência nas doses de $10^{1}$ a $10^{4}$ (CSs7, CSs11, CSs14, CSs17 e CSs19) e as linhagens parentais isogênicas C57BL/6/Unib (resistente), nas doses de $10^{1}$ a $10^{5}$ e A/JUnib (susceptível), na dose de $10^{1}$ -

Tabela 8a: Resultados da comparação entre machos e fêmeas das linhagens recombinantes consômicas de primeira geração após infecção com as doses de $10^{1}$ a $10^{4}$ tripomastigotas de 
T. cruzi-a.

Tabela 8b: Resultados da comparação entre machos e fêmeas das linhagens recombinantes consômicas de primeira geração após infecção com as doses de $10^{1}$ a $10^{4}$ tripomastigotas de $T$. cruzi-

Tabela 9: Resultados dos comparativos na sobrevivência observada entre as linhagens recombinantes consômicas de primeira geração que apresentaram resistência nas doses de $10^{1}$ a $10^{4}(7 \times 11$, $7 \times 14,7 \times 17,7 \times 19,11 \times 19$ e $17 \times 19)$ e as linhagens parentais isogênicas C57BL/6/Unib (resistente), nas doses de $10^{1}$ a $10^{5} \mathrm{e}$ A/JUnib (susceptível), na dose de $10^{1}$

Tabela 10: Período de mortalidade observado após infecção da linhagem isogênica parental susceptível A/JUnib, usada como controle positivo em todos os experimentos nas doses de $10^{1}$ a $10^{4}$

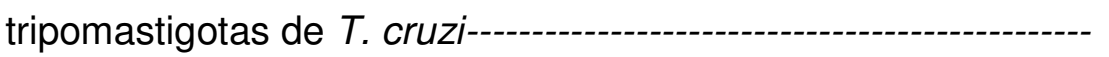

Tabela 11: Período de mortalidade observado nos grupos experimentais de infecção das linhagens consômicas CSs7, CSs11, CSs14, CSs17 e CS19 nas doses de $10^{1}$ a $10^{4}$ tripomastigotas de $T$. Cruzi-

Tabela 12: Período de mortalidade observado nos grupos experimentais de infecção das linhagens recombinantes consômicas de primeira geração nas doses de 101 a 104 tripomastigotas de T. cruzi- 


\section{LISTA DE FIGURAS}

Figura 1: Distribuição da doença de Chagas nos países considerados

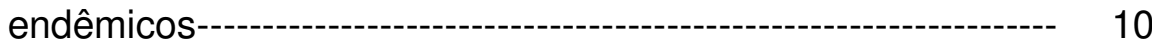

Figura 2: Casos de DCA ocorridos no Brasil por transmissão oral de 2000 até 2008

Figura 3: Linhagem isogênica C57BL/6J

Figura 4: Linhagem isogênica $A / J$

Figura 5: Linhagem isogênica CBA/J

Figura 6: Rack ventilada ALESCO $\AA$, com 56 mini-isoladores utilizada para manutenção dos casais em reprodução

Figura 7: Rack ventilada $A L E S C O \Theta$, com 25 mini-isoladores com capacidade de até 30 camundongos para manutenção dos estoques de machos e fêmeas dos experimentos

Figura 8: Esquema de obtenção de consômico - Produção e seleção de F2 recombinantes: 1-) acasalamento entre as linhagens parentais C57BL/6/Unib (doadora), de perfil resistente $e$ A/JUnib (receptora), de perfil susceptível para produção de F1 híbridos; 2-) acasalamentos entre F1 (intercross) para produção de F2 recombinantes; 3-) genotipagem dos recombinates F2 para direcionamento do perfil (BB) resistente para os cromossomos 7, 11, 14, 17 e 19 de camundongo. $\mathrm{O}$ destaque é um exemplo de $\mathrm{F} 2$ recombinante especialmente selecionado para a produção de consômico do cromossomo 7 (CSs7)-----

Figura 9: Esquema de obtenção de consômico a partir de F2 recombinantes, selecionados por genotipagem, com perfil (BB) resistente nos cromossomos 7, 11, 14, 17 e 19 de camundongo: 1-) acasalamentos em backcross dos F2 selecionados com a linhagem $A / J U n i b$ receptora, de perfil susceptível; 2-) Acasalamentos em intercross, dos descendentes heterozigotos; 3-) filhos do intercross genotipados para seleção do perfil (BB) resistente nos 
cromossomos de interesse; 4-) repetições de acasalamentos em backcross com a linhagem A/JUnib receptora, de perfil susceptível, seguidos de intercross entre heterozigotos e genotipagem dos descendentes para seleção do perfil resistente até a $6^{a}$. geração de intercross

Figura 10: Imagem de eletroforese em gel de agarose a $4 \%$ com os resultados da certificação genética das linhagens parentais C57BL/6/Unib (resistente), A/JUnib (susceptível) e CBA/JUnib (manutenção in vivo de T. cruzı). Foram testadas 2 amostras de DNA de cada linhagem parental, comparadas com os padrões das linhagens (Banco de DNA CEMIB) nos seguintes primers: D6mit254 (cromossomo 6), D7mit31 e D7mit301 (cromossomo 7), D14mit165 (cromossomo 14), D15mit246 (cromossomo 15), de D17mit88 e D17mit176 (cromossomo 17) e D19mit19 (cromossomo 19). As amostras e os padrões também foram comparadas com o padrão de peso molecular ( $\phi 174$ - ao centro da imagem) e não apresentaram diferenças de migração, como o esperado para estas linhagens, segundo os pesos moleculares, indicados na imagem

Figura 11: Diferenças de parasitemia ( $n^{\circ}$ de parasitos $\times 30000$-fator de correção) na linhagem consômica CSs7 com as doses de $10^{1}$ a $10^{4}$ tripomastigotas de T. cruzi, no período do $13^{\circ}$ ao $39^{\circ}$ dia após infecção (dpi)

Figura 12: Diferenças de parasitemia ( $n^{\circ}-$ de parasitos $\times 30000$-fator de correção) na linhagem consômica CSs 11 com as doses de $10^{4}$ a $10^{4}$ tripomastigotas de $T$. cruzi, no período do $13^{\circ}$ ao 29ํำ dia após infecção (dpi)

Figura 13: Diferenças de parasitemia ( $\mathrm{n}^{\circ}$ de parasitos $\times 30000$-fator de correção) na linhagem consômica CSs 14 com as doses de $10^{1}$ a $10^{4}$ tripomastigotas de T. cruzi, no período do $13^{\circ}$ 
ao $32^{\circ}$ dia após infecção (dpi)

Figura 14: Diferenças de parasitemia ( $n^{\circ}$ de parasitos x 30000-fator de correção) na linhagem consômica CSs17 com as doses de $10^{1}$ a $10^{4}$ tripomastigotas de $T$. cruzi, no período do $13^{\circ}$ ao 34ํ dia após infecção (dpi)

Figura 15: Diferenças de parasitemia ( $n^{\circ}$ de parasitos x 30000-fator de correção) na linhagem consômica CSs19 com as doses de $10^{1}$ a $10^{4}$ tripomastigotas de T. cruzi, no período do $13^{\circ}$ ao $32^{\circ}$ dia após infecção (dpi)

Figura 16: Curva para comparação entre o número de parasitos circulantes (multiplicado pelo fator de correção de 30000) apresentados nas linhagens consômicas CSs7, CSs11, CSs14, CSs17 e CSs19, com a dose de 10 tripomastigotas de T. cruzi, no período do 13ำ ao 29ำ dia após infecção (dpi)

Figura 17: Curva para comparação entre o número de parasitos circulantes (multiplicado pelo fator de correção de 30000) apresentados nas linhagens consômicas CSs7, CSs11, CSs14, CSs17 e CSs19, com a dose de 100 tripomastigotas de $T$. cruzi, no período do $11^{\circ}$ ao $29^{\circ}$ dia após infecção (dpi)

Figura 18: Curva para comparação entre o número de parasitos circulantes (multiplicado pelo fator de correção de 30000) apresentados nas linhagens consômicas CSs7, CSs11, CSs14, CSs17 e CSs19, com a dose de 1000 tripomastigotas de $T$. cruzi, no período do $9^{\circ}$ ao $27^{\circ}$ dia após infecção (dpi)

Figura 19: Curva para comparação entre o número de parasitos circulantes (multiplicado pelo fator de correção de 30000) apresentados nas linhagens consômicas CSs7, CSs11, CSs14, CSs17 e CSs19, com a dose de 10000 tripomastigotas de $T$. cruzi, no período do $7^{\circ}$ ao $27^{\circ}$ dia após infecção (dpi) 
Figura 20: Porcentagem de sobrevivência das linhagens consômicas CSs7, CSs11, CSs14, CSs17 e CS19 nas doses de 10, 100, 1000 e 10000 tripomastigotas de T. cruzi-------.--..-

Figura 21: Porcentagem de sobrevivência das linhagens recombinantes consômicas de primeira geração $(7 \times 11$, $7 \times 14,7 \times 17,7 \times 19,11 \times 19$ e 17x19) nas doses de 10, 100, 1000 e 10000 tripomastigotas de T. cruzi ----------------

Figura 22: Porcentagem de sobrevivência comparando machos e fêmeas infectados com 10 tripomastigotas de $T$. cruzi para todas as linhagens que apresentaram sobrevivência, sendo três linhagens consômicas CSs7, CSc17 e CSs19 e seis linhagens recombinantes consômicas de primeira geração 7×11, 7×14, 7×17, 7×19,11×19 e 17×19 ----------- 


\section{INTRODUÇÃO}

A doença de Chagas é uma zoonose causada pelo protozoário hemoflagelado Trypanosoma cruzi, mantida na natureza por reservatórios (marsupiais, roedores) e vetores (triatomíneos).

Até o início do século $X X$, esta doença era uma enzootia presente em populações de animais silvestres de espécies variadas. Entretanto, com as mudanças no ambiente decorrentes da ocupação humana, o panorama se modificou, e atualmente esta doença se configura em um importante problema de saúde pública, com ampla distribuição na América Central e Sul, estendendo-se desde o Sul dos Estados Unidos até a Argentina (Szajnman et al., 2005).

Embora a prevalência da infecção no continente americano tenha decaído cerca de $70 \%$ por volta do ano 2000 (Moncayo, 2003) estima-se que ainda existam entre 10 milhões de infectados e cerca de 25 milhões sob o risco de contrair a infecção na América Latina (WHO, 2010¹).

Em 2008, segundo dados da Organização Mundial de Saúde, cerca de 10.000 pessoas morreram em decorrência da Doença de Chagas. Na América do Sul, principalmente Argentina, Brasil, Chile, Uruguai e Venezuela, a doença de Chagas constitui grave e alarmante problema de saúde pública, sendo que o risco de morte de uma pessoa chagásica é duas vezes maior do que o de uma pessoa saudável. No Brasil, estima-se que a população infectada seja de 3 milhões, 60\% presentes na área urbana (Dias et al., 2000; Brener et al., 2000; WHO, 201011), levando a um custo social para o país em cerca de 1 bilhão de reais ao ano (Bestetti et al., 2009)

Segundo o Ministério da Saúde $\left(2006^{2}\right)$, em função de ações de controle de vetores estabelecidos a partir da década de 1980, em 2006 o Brasil recebeu a Certificação Internacional pela Interrupção da Transmissão de Doença de Chagas pelo Triatoma infestans, espécie responsável pela maior parte da transmissão vetorial no passado.

\footnotetext{
${ }^{1}$ http://www.who.int/mediacentre/factsheets/fs340/en/June 2010Chagas disease

${ }^{2} \mathrm{http}: / /$ portal.saude.gov.br/portal/arquivos/pdf/nota_chagas0206.pdf
} 
Porém, devido à migração do campo para as grandes cidades houve mudança no perfil epidemiológico da Doença de Chagas, assumindo importância outras vias de contaminação tais como a transfusional, congênita, por transplantes de órgãos, por acidentes laboratoriais (Dias et al., 2000) e mais recentemente por via oral, pois ao contrário do que se pensava, é possível a sobrevivência do parasita mesmo na presença dos ácidos estomacais (Camandaroba et al., 2002).

A transmissão oral agrava o problema do ponto de vista epidemiológico, porque induz a uma nova reflexão sobre doença associada ao subdesenvolvimento, uma vez que a ingestão de parasitos em alimentos amplia sobremaneira a infecção de indivíduos que habitam regiões não endêmicas.

No final do século passado, a doença de Chagas foi considerada pelo Banco Mundial, como a mais importante das doenças parasitárias, por apresentar um impacto sócio econômico significativamente maior que o obtido do efeito combinado de todas as outras infecções causadas por parasitas (PAHO, 2003).

A doença apresenta uma fase aguda, que pode ou não ser identificada (Doença de Chagas aguda - DCA), porém é freqüente a sua evolução para as formas crônicas (indeterminada, cardíaca, digestiva), para as quais ainda não existem tratamentos efetivos.

Entre os sintomas crônicos, o principal é a insuficiência cardíaca, a qual pode conduzir à morte súbita.

Outro aspecto importante é que freqüentemente o doente crônico é marginalizado pela sociedade, pois esta, erroneamente, muitas vezes 0 impossibilita de trabalhar, fato que, além de sobrecarregar os órgãos de previdência social com aposentadorias precoces, desperta no chagásico a sensação de fragilidade, comprometendo a sua auto-estima, a sua saúde psicológica e por conseguinte, a sua qualidade de vida.

\subsection{Camundongos x Trypanosoma cruzi}

Grande parte do conhecimento atual em genética de mamíferos deriva dos estudos iniciados com camundongos no princípio do século passado. Com a ajuda destes modelos, inúmeros eventos relacionados com a compreensão da patogenicidade de várias doenças foram esclarecidos (Godard \& Guénet, 1999). 
Os roedores de laboratório suportam relativamente bem um regime de cruzamentos totalmente consangüíneos, os quais conduzem a populações de animais muito homogêneas do ponto de vista genético. Essas populações, denominadas linhagens isogênicas, além de muito estáveis, são geneticamente padronizadas e dessa forma, fica claro que toda comparação feita entre camundongos provenientes de linhagens isogênicas diferentes, revelará também as diferenças genéticas, possibilitando o estudo de genes e mecanismos envolvidos no controle de doenças ou na resistência a agentes patogênicos. É fato, enquanto algumas linhagens são dizimadas pela infecção de um agente patogênico, outras são resistentes, controlando a doença e sobrevivendo.

Desta forma, estudos empregando linhagens de camundongos com 0 propósito de se identificar regiões do genoma importantes para a sobrevivência na infecção por patógenos serão cada vez mais freqüentes, e as estratégias terão como base a constituição genética dos modelos, considerando a variação de resistência ou susceptibilidade apresentada pelas diversas linhagens isogênicas.

No que diz respeito à resistência ao Trypanosoma cruzi, estudos com infecções experimentais empregando este protozoário e camundongos de laboratório, demonstraram a importância da constituição genética do hospedeiro na sobrevivência e apontaram para a necessidade de se realizar experimentos especificamente desenhados, com o propósito de esclarecer a influência de cromossomos e regiões do genoma relacionadas a este fenômeno (Corsini et al., 1980; Wrightsman et al., 1982; Passos et al., 2003).

Por se tratar de uma doença multifatorial de trato complexo, a doença de Chagas possui um componente genético sofisticado, envolvendo diversos genes e suas expressões.

Estudos dirigidos à compreensão do fenômeno da resistência de camundongos isogênicos à cepa $Y$ de T.cruzi, demonstraram que as linhagens, comportaram-se diferentemente frente a infecção. Enquanto a linhagem A/J, por exemplo, morre ainda na fase aguda com $10^{1}$ formas $/ \mathrm{ml}$ de tripomastigotas injetados intraperitonialmente, a linhagem C57BL/6 pode sobreviver com doses de até $10^{5}$ formas/ml (Passos et al., 2003; Di Marco, 2003; Graefe et al., 2006).

Ensaios de infecção experimental empregando camundongos recombinantes, revelaram regiões envolvidas com a resistência. Nestes estudos, a progênie derivada do cruzamento das linhagens parentais A susceptível e 
C57BL/6 resistente foi desafiada com altas doses do parasito, e indicaram regiões presentes nos cromossomos 7, 11, 14, 17 e 19, como importantes para a sobrevivência dos animais (Passos et al., 2003).

Esforços no sentido de esclarecer a importância destes cromossomos tanto isoladamente, como após uma associação, devem ser realizados, uma vez que podem contribuir para o esclarecimento do complexo mecanismo de resistência à cepa $Y$ do Trypanosoma cruzi, com reflexos sobre a qualidade de vida das pessoas infectadas.

No presente estudo foram produzidas e empregadas linhagens consômicas de camundongos para estudar a influência dos cromossomos 7, 11, 14, 17 e 19 na sobrevivência após a inoculação de diferentes doses do parasito. 


\section{OBJETIVOS}

Geral:

Avaliar a resistência genética em camundongos infectados com tripomastigotas da cepa $Y$ do Trypanosoma cruzi.

\section{Específicos:}

- Produzir as linhagens consômicas de camundongos para os cromossomos 7 (CSs7), 11 (CSs11),14 (CSs14), 17 (CSs17) e 19 (CSs19);

- Empregar modelos consômicos para avaliar a importância dos cromossomos 7, 11, 14, 17 e 19 isoladamente, na resitência a diferentes doses de tripomastigotas da cepa $Y$ do $T$. cruzi;

- Produzir modelos recombinantes consômicos de primeira geração, a partir de acasalamentos programados entre as linhagens consômicas;

- Avaliar a sobrevivência de modelos recombinantes consômicos de primeira geração, após o desfio com diferentes doses da cepa $Y$ do T. cruzi. 


\section{REVISÃO DA BIBLIOGRAFIA}

\subsection{A doença de Chagas}

\subsubsection{História}

A História da Doença de Chagas iniciou-se em 1902, quando o estudante da Faculdade de Medicina do Rio de Janeiro Carlos Ribeiro Justiniano Das Chagas começou a freqüentar o órgão de pesquisa Instituto Soroterápico, interpelado pelo pesquisador Miguel Couto (Brener, 1989).

Em 1907, a pedido de Oswaldo Cruz, seu orientador, segue para o norte de Minas Gerais, pela Estrada de Ferro Central do Brasil, com destino ao vilarejo de Lassance, com o objetivo de investigar e controlar um surto de malária entre os operários (Brener, 1989) e acaba por descrever, em 1909 não só a doença de Chagas, que levaria seu nome, mas o vetor e o seu agente etiológico. Este feito foi e ainda é considerado raro na ciência mundial.

Sabe-se hoje que a doença de Chagas acomete humanos há milhares de anos nas Américas, onde estudos realizados em corpos mumificados encontrados no deserto do Atacama, região mais árida do planeta, entre o norte do Chile e o Sul do Peru revelaram lesões típicas da doença e a presença de T.cruzi foi constatada em análises histológicas (Rothhammer, 1985).

\subsubsection{Epidemiologia e distribuição geográfica}

A Doença de Chagas está entre as principais doenças parasitárias no mundo. Estimativas apontam para 10 milhões de pessoas infectadas em todo o planeta, sendo a maioria na América Latina, onde a doença é considerada endêmica. Cerca de 25 milhões de pessoas estão expostas ao risco de se contaminarem e em 2008 foram atribuídas mais de 10.000 mortes à doença de Chagas (WHO, 2010 ${ }^{1}$ ).

No Brasil, estima-se que três milhões de pessoas estejam infectadas pelo

Trypanosoma cruzi. Estes números demonstram a importância da doença de Chagas no aspecto social e econômico, onde desde a sua descoberta, há cem anos, completados recentemente em 2009, até a década de 60, não era vista

$\overline{{ }^{3} \text { http://www.msf.org.br/Arquivos/Doc/Publicacoes/56.pdf }}$ 
como um problema de saúde pública (WHO, 2010; Médicos sem fronteira, $\left.2010^{3}\right)$.

Considerada endêmica em países da América Latina e Central, a doença está avançando para outras partes do mundo devido à imigração de latinoamericanos. Cada vez mais são freqüentes casos nos Estados Unidos, Canadá, em países da Europa, na Austrália e no Japão (Médicos sem fronteira, 2010³ WHO, 2007), em conseqüência de transfusão de sangue associada a transmissão, pois enquanto muitos países endêmicos realizam o screening no sangue de doadores, outros não o fazem (Teixeira et al., 2006). Outras formas de transmissão relacionadas à imigração são a vertical e pela doação de órgãos. (WHO, 2010 ${ }^{1}$.

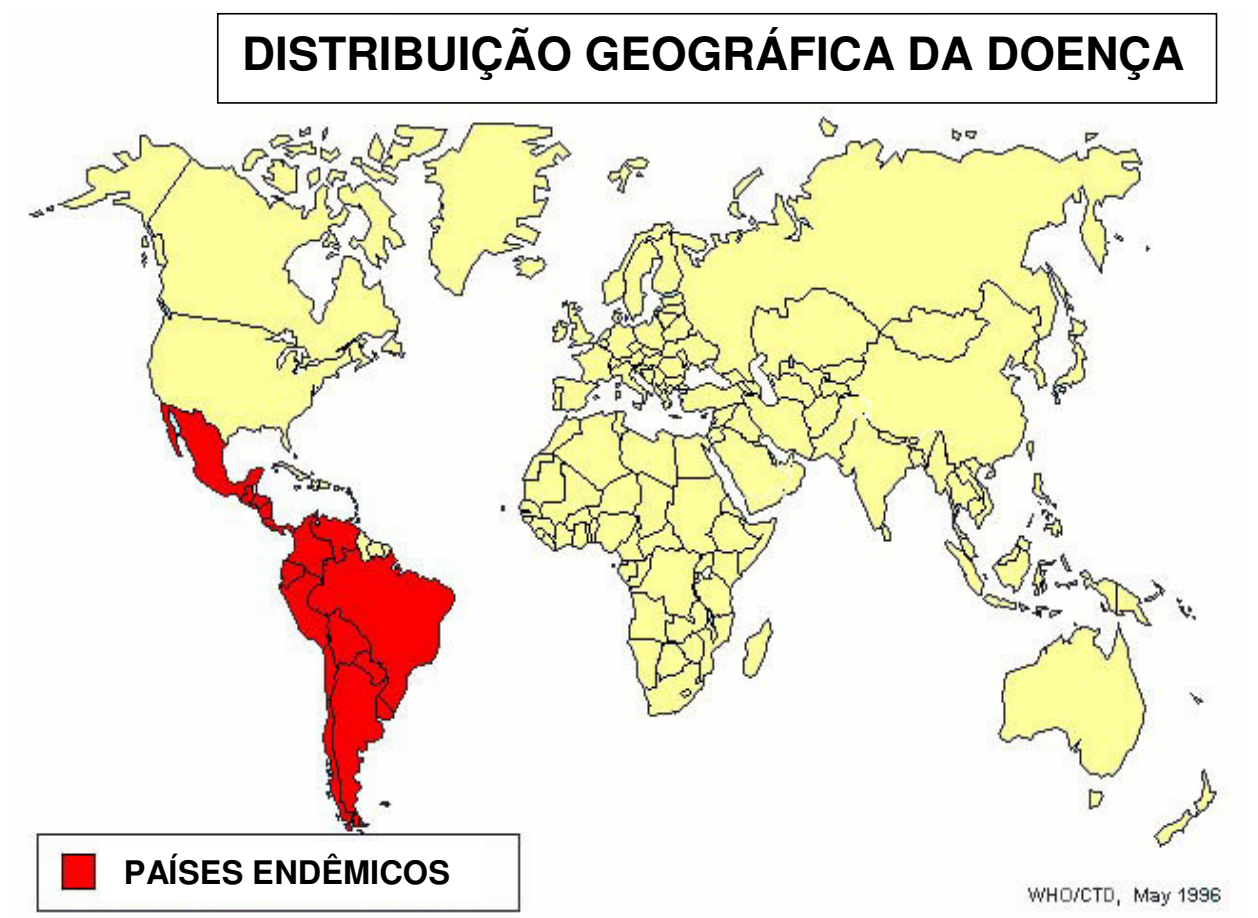

FIGURA 1: Distribuição da doença de Chagas nos países considerados endêmicos.

Fonte: WHO/CTD, 1996

\subsubsection{Iniciativas governamentais no combate à doença}

A doença de Chagas figura entre as chamadas negligenciadas, devido a fatores como falta de investimento em prevenção, tratamento e pesquisa. Desde o seu descobrimento, Carlos Chagas apontava para a necessidade da eliminação 
do inseto vetor e o afastamento de animais domésticos nas moradias, por serem estes reservatórios naturais de T.cruzi (Lewinsohn, 2005).

Atualmente, iniciativas adotadas pela OMS e pelos governos da América Latina, são empregadas como forma de controlar a transmissão vetorial nas áreas endêmicas. No Brasil, segundo informações do portal da saúde ${ }^{4}$, ações sistematizadas de controle químico, que foram instituídas a partir de 1975, e mantidas em caráter regular desde então, levaram a uma expressiva redução da transmissão vetorial do Tripanossoma cruzi ao homem e a conseqüente diminuição da densidade triatomínica domiciliar (SVS, 2005). Estas ações garantiram ao Brasil em 2006, a certificação internacional de interrupção da transmissão da doença pelo T.infestans, o principal vetor. Até a década de 70 , estimava-se que a via vetorial era responsável por $80 \%$ das infecções humanas.

A redução da transmissão vetorial resultou também na diminuição de gestantes e de doadores de sangue infectados, o que reduziu os riscos de transmissão transfusional e congênita (Ferreira \& Silva, 2006). Mas além destas ações preventivas são necessárias outras, dirigidas para o desenvolvimento de novas ferramentas para diagnóstico nas formas aguda, crônica e congênita da doença, assim como melhores tratamentos nas diferentes fases da infecção além da assistência aos doentes (Lannes-Vieira, 2010 ). Neste sentido, a inexistência de vacina e a falta de um tratamento eficaz, são os principais desafios para os doentes crônicos.

Segundo Pereira et al. (2009, 2010), esforços também devem ser concentrados na prevenção da DCA transmitida por via oral, que é atualmente uma preocupação das autoridades de saúde. A implementação de procedimentos operacionais padrão e boas práticas na manufatura de alimentos, assim como o desenvolvimento de metodologias para detectar T.cruzi diretamente nos alimentos e o uso de técnicas de inativação do parasito, como a pasteurização de polpas e sucos de frutas são necessários no combate à doença transmitida pela via oral.

Além disso, são ainda necessárias ações para a orientação e apoio à pesquisa à Doença de Chagas na infecção por HIV e outras formas de imunossupressão, uma vez que há evidências na literatura científica nacional e

\footnotetext{
${ }^{4}$ http://portal.saude.gov.br/portal/saude/profissional/visualizar_texto.cfm?idtxt=31454

${ }^{5} \mathrm{http}: / / \mathrm{www}$. fiocruz.br/chagas/cgi/cgilua.exe/sys/start.htm?sid=25
} 
internacional, de que a doença de Chagas pode apresentar um comportamento oportunista (Almeida et al., 2009).

"A doença de Chagas é um problema atual, global e negligenciado. Ela não interessa à indústria farmacêutica pelo perfil econômico dos pacientes, geralmente pessoas economicamente desfavorecidas."(David de Souza, médico coordenador da Unidade Médica de MSF-Médicos sem fronteiras/Brasi ${ }^{3}$ )

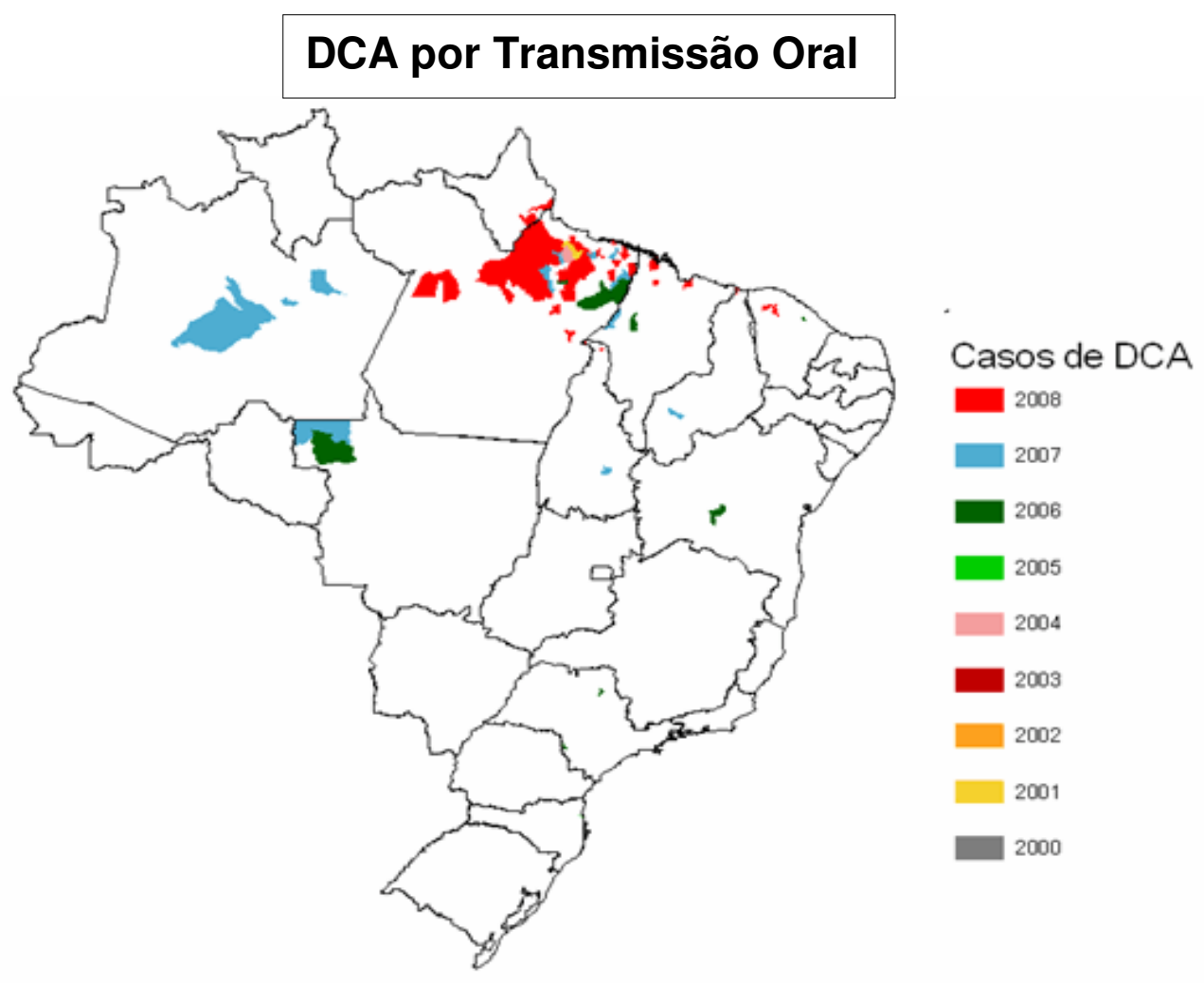

FIGURA 2: Casos de DCA ocorridos no Brasil por transmissão oral de 2000 até 2008 Fonte: SVS/MS in: Valente et al.; Pinto et al.

\subsubsection{O agente Trypanosoma cruzi e o seu ciclo de vida}

O Trypanosoma cruzi é um protozoário parasita homoflagelado, membro da ordem Kinetoplastida da família Trypaosomatidae, assim como os parasitas causadores da tripanosomíase Africana e Leishimaniose (WHO, 2009).

Existem muitas linhagens de T.cruzi identificadas e elas são divididas em dois grupos principais, T.cruzi I e T.cruzi II, sendo o segundo geralmente o causador das infecções humanas. 
Alguns estudos biológicos em modelos experimentais utilizando marcadores isoenzimáticos permitiram classificar as cepas de $T$. cruzi em três biodemas I, II e III (Andrade \& Figueira, 1970).

O biodema I, cujo protótipo é a cepa $\mathrm{Y}$, caracteriza-se por macrofagotropismo, elevada parasitemia e altas taxas de mortalidade na fase aguda da infecção, onde predominam as formas delgadas do parasito (Andrade et al., 1970).

As cepas do biodema II possuem multiplicação lenta, picos de parasitemia irregulares e mortalidade variável. Finalmente o biodema III, representado pela cepa Colombiana caracteriza-se por baixa taxa de multiplicação e picos de parasitemia tardios. Os parasitos possuem forma larga e acometimento predominante da musculatura esquelética (Andrade \& Figueira, 1970).

A heterogeneidade genética do parasito pode ser observada através da sua variação biológica tanto em estudos com modelos experimentais, como na expressão clínica da doença no homem (Schimuñis, 2000), além de ser correlacionada com os ciclos doméstico e silvestre de transmissão (Miles, 1981).

Miles et al., (1981), em seus estudos demonstraram formas clínicas claramente divergentes da doença em pacientes crônicos no Brasil e na Venezuela, os quais haviam sido infectados por populações distintas do parasito.

O T.cruzi possui diferentes estágios em seu ciclo de vida, envolvendo hospedeiros vertebrados, com mais de 100 espécies de mamíferos de diferentes ordens, entre eles os seres humanos, animais silvestres e animais domésticos, embora todos os mamíferos sejam considerados susceptíveis e também hospedeiros invertebrados, que são os insetos da família Reduviidae, subfamília Triatominae (WHO, 2009; Azambuja \& Garcia, 20106).

No tubo digestivo do inseto triatomíneo, o parasita se apresenta na forma replicativa epimastigota e então se desenvolve para a forma não replicativa, porém infectante tripomastigota metacíclico, presente nas fezes e urina do inseto (Von et al., 2007; Azambuja \& Garcia, 20106).

Em condições naturais, o inseto se alimenta do sangue de mamíferos, excretando através de suas fezes e urina o parasita, que penetra na pele ou

${ }^{6}$ http://www.fiocruz.br/chagas/cgi/cgilua.exe/sys/start.htm?sid=11 
mucosa da vítima. Uma vez circulantes no sangue, os tripomastigotas infectam as células hospedeiras, e no citoplasma transformam-se em amastigotas aflagelados.

A partir daí, a replicação ocorre por fissão binária, originando os tripomastigotas flagelados, que deixam as células e ganham a circulação sanguínea para infectar outras células (Von et al., 2007; Azambuja \& Garcia, $\left.2010^{6}\right)$.

É neste momento, em que os parasitas estão na circulação do mamífero infectado, que o ciclo se completa. O inseto triatomíneo ingere o sangue com T.cruzi (Von et al., 2007), iniciando um novo ciclo, quando após alguns dias os parasitas se transformam em epimastigotas e esferomastigotas, estabelecem a infecção no estômago do inseto, quando então se replicam, diferenciando-se em tripomastigotas metacíclicos. Ambas as formas, diferenciadas ou não, podem ser eliminadas pelas fezes e urina do inseto (Azambuja \& Garcia, 20106).

Esta manutenção do ciclo do T.cruzi entre mamíferos e insetos dificulta ou mesmo impede a completa erradicação do mesmo, apesar de medidas eficazes de controle, como observado em outras zoonoses.

\subsubsection{Formas de transmissão da doença}

\subsubsection{Transmissão vetorial}

Acontece através da picada do inseto triatomíneo, seguida de seu repasto, que provoca intensa coceira. No momento em que a vítima coça o local, os parasitos depositados penetram na pele, alcançando posteriormente a corrente sanguínea (Lewinsohn, 2005). A transmissão vetorial pode ocorrer ainda pelo contato direto das fezes do inseto com a mucosa ocular ou oral (Gontijo \& Santos, $2010^{7}$ ).

\subsubsection{Transmissão transfusional}

É a segunda via de transmissão mais importante, sendo a principal em países não endêmicos.

Cerca de $20 \%$ das pessoas que recebem o sangue infectado têm o risco de contrair a Doença de Chagas pela via transfusional, a qual é 10 a 15 vezes

${ }^{7}$ http://www.fiocruz.br/chagas/cgi/cgilua.exe/sys/start.htm?sid=25 
menor que HIV, HBV ou HCV, o que reflete a efetividade da vigilância de saúde sobre os serviços de hemoterapia públicos e privados (WHO, 2007; Gontijo \& Santos, $2010^{7}$ ).

Esta via de transmissão está ligada diretamente aos seguintes fatores: parasitemia no momento da doação, volume de sangue, estado imunológico do receptor, prevalência da infecção entre os candidatos à doação, qualidade do sangue e outros (Gontijo \& Santos, 20107).

Exceto o plasma liofilizado e derivados expostos a processos físicoquímicos de esterilização, todos os componentes do sangue são infectantes (Gontijo \& Santos, 20107).

\subsubsection{Transmissão oral}

Desde que estudos revelaram a possibilidade da doença ocorrer pela ingestão de alimentos contaminados com T.cruzi, vários pesquisadores ressaltam a importância desta via para a transmissão. Entretanto, apenas recentemente, com os casos de Doença de Chagas Aguda ocorridos no estado brasileiro de Santa Catarina em 2005 e vários outros na região amazônica nos últimos três anos, a transmissão oral ganhou notoriedade. Também em Caracas, na Venezuela, em 2007 foi relatado a transmissão por ingestão de suco de frutas (Pereira et al., 2009).

Geralmente estes surtos acontecem em locais definidos, com pequeno número de pessoas, nas épocas de calor, onde os insetos triatomíneos estão em maior atividade. Os vetores são freqüentemente encontrados nas imediações da área de produção, manuseio ou utilização de alimentos contaminados, que podem ser sopas, caldos, sucos de cana ou açaí, comida caseira, leite, carne de caça semicrua entre outros (Gontijo \& Santos, 20107).

Segundo Barbosa-Labello, 2010, em seus estudos in vitro e in vivo com DCA oral em camundongos, o T. cruzi foi capaz de sobreviver e preservar sua virulência na polpa de açaí após ser mantido por até 24 horas à temperatura ambiente, por até 144 horas à temperatura de refrigeração $\left(4^{\circ} \mathrm{C}\right)$ e por até 26 horas de congelamento $\left(-20^{\circ} \mathrm{C}\right)$.

\subsubsection{Transmissão congênita ou vertical}

A transmissão congênita ou vertical ocorre em crianças nascidas de 
mães com sorologia positiva para T. cruzi, após descartados outros mecanismos de transmissão. É necessário identificar os parasitos no sangue do recém-nascido e/ou anticorpos de origem não materna (após 6 a 9 meses de idade) (SVS, 2005).

Esta forma de transmissão acontece em qualquer uma das fases da doença, aguda, intermediária ou crônica e em qualquer época da gestação, embora mais provavelmente no último trimestre. Pode também ocorrer durante a passagem pelo canal do parto, através do contato das mucosas do feto com o sangue da mãe (Gontijo \& Santos, 2010 ${ }^{7}$ ).

Pouco é conhecido sobre os fatores que possibilitam uma mãe de transmitir a doença numa gestação e não na seguinte. Porém, deve tanto ser considerado o grau de parasitemia da mãe em cada gestação, como fatores placentários, obstetrícios, imunitários e nutricionais. Além disso, durante a gestação, há uma depressão transitória da imunidade, para que não haja rejeição do feto, o que torna maior a susceptibilidade a infecções (Gontijo \& Santos, $2010^{7}$ ).

No Brasil, a transmissão vertical é discreta, com risco de $1 \%$ ou menos, tendendo a decrescer (Dias, 2006).

\subsubsection{Transmissão pelo leite materno}

Há poucos casos descritos na literatura sobre a transmissão da Doença de Chagas pelo leite materno, o que denota pouca importância no contexto de endemia (Gontijo \& Santos, $2010^{7}$ ). Ainda assim, esta via de transmissão não deixa de ser reconhecida como alternativa e por isso merece atenção no sentido da prevenção. Segundo Ferreira et al., 2003, em seu estudo com camundongos, um simples processo, que consiste em aquecer o leite em microondas por sete minutos, em potência média mostrou ser eficiente para inativar tripomastigotas, evitando assim a contaminação pelo leite materno.

\subsubsection{Transmissão por acidentes de laboratório}

Pode ocorrer através do contato com culturas de T.cruzi ou exposição com as fezes infectadas de triatomíneos (Gontijo \& Santos, 2010 ${ }^{7}$ ).

O sangue de paciente ou animal com formas tripomastigotas também podem causar infecções ao contato com mucosas ou micro lesões da pele. Assim como a exposição parenteral com agulhas nos procedimentos experimentais 
como a inoculação em animais (Gontijo \& Santos, 20107).

\subsubsection{Transmissão por transplante de órgãos}

Nesta forma de transmissão a Doença de Chagas apresenta-se mais agressiva, uma vez que os receptores estão imunocomprometidos.

O transplante de órgãos também é via para a transmissão da doença em países não endêmicos.

\subsubsection{Apresentação clínica da doença: sinais e sintomas}

O conhecimento do caso clínico é um evento raro no período patogênico inicial. Quando conhecido um caso agudo, muitos outros terão ocorrido. Por outro lado, o caso crônico reflete, do ponto de vista da transmissão, uma situação passada e remota (SVS, 2005).

\subsubsection{Doença de Chagas aguda (DCA)}

A fase aguda é precedida por uma incubação de 7 a 15 dias, podendo apresentar um chagoma no local da inoculação. Se ocorrer a inoculação conjuntiva, esta poderá ser caracterizada por um edema periorbital, conhecido como "Sinal de Romaña". Porém, esta fase pode ser assintomática ou ainda manifestada por febre, taquicardia, vômito, diarréia, anorexia e outros. Somente 1 a $2 \%$ dos casos agudos são reconhecidos devido ao acesso limitado ao sistema de saúde e simplesmente pelo desconhecimento dos sintomas, que cessam espontaneamente sem deixar seqüelas (Von et al., 2007; Teixeira et al., 2006).

\subsubsection{Doença crônica}

\subsection{Fase crônica indeterminada}

A fase indeterminada da Doença de Chagas pode durar muitos anos, sem manifestar sintomas. Os indivíduos infectados são identificados geralmente em exames periódicos do trabalho ou em screening de banco de sangue. Cerca de $30 \%$ dos indivíduos nesta fase desenvolverão a fase crônica (Teixeira et al., 2006). 


\subsection{Fase crônica cardíaca e digestiva}

Nesta fase, as lesões irreversíveis ocorrem de 20 a 35 anos após a infecção e as principais manifestações no coração e trato digestivo representam significante morbidade e mortalidade dos pacientes (Von et al., 2007).

No coração, infiltrações inflamatórias e fibroses no tecido cardíaco causam alterações estruturais, produzindo seqüelas graves, como arritmias, falência congestiva e troboembolismo pulmonar. A cardiomiopatia, que é a mais comum manifestação, se caracteriza pela dilatação biventricular e aneurisma, sendo ainda mais grave que outras formas de falências cardíacas (Von et al., 2007).

No sistema digestivo, os sintomas são o magaesôfago, o qual provoca dor na deglutinação e regurgitação, assim como tosse, má-nutrição, bronquite ou pneumonia, onde é grande a incidência de câncer gástrico e esofágico nos pacientes, e o megacólon, que causa constipação e dor, com sérias complicações tais como impactação fecal e megacólon tóxico (Von et al., 2007).

\subsubsection{Diagnóstico}

$\mathrm{Na}$ fase aguda, o diagnóstico parasitológico é realizado pela identificação direta do tripomastigota no sangue periférico (WHO, 2009).

Em 1994, Luz et al. demonstraram ser a hemocultura um método sensível no diagnóstico parasitológico da doença de Chagas e para monitorar a cura de pacientes submetidos ao tratamento.

Após a fase aguda, a resistência imune à infecção adquirida pelo hospedeiro pode gerar resultados negativos, por isso a constatação nesta fase deve ser através de testes sorológicos de imunoflorescência indireta, hemaglutinação indireta e ELISA, que reconhecem os anticorpos antiparasitários, confirmando assim o diagnóstico para a doença de Chagas (WHO, 2009).

Recentemente, alguns trabalhos demonstram que técnicas moleculares podem ser ainda mais precisas.

A alta especificidade destas técnicas apontam sua excelência para a aplicação como métodos confirmatórios no diagnóstico de pacientes com exames sorológicos duvidosos e também como métodos para o monitoramento pósterapêutico da doença crônica, em comparação às técnicas sorológicas e parasitológicas. Porém, seu emprego é restrito na rotina diagnóstica pela pouca 
infra-estrutura adequada, facilidade de contaminação e alto custo (PortelaLindoso et al., 2003, Ministério da Saúde, 2005).

A PCR em tempo-real é uma técnica molecular que Freitas (2009) demonstrou ser capaz de detectar níveis parasitêmicos em diferentes perfís de pacientes, tais como os infectados por HIV/T. cruzi, sem reativação da doença crônica, assim como pacientes co-infectados por HIV/T. cruzi. Esta técnica apresentou uma sensibilidade maior que o xenodiagnóstico e a hemocultura (Piron et al., 2007).

Ainda Duffy et al. (2009) ressaltaram que a combinação de técnicas moleculares como Q-PCR e Lg-PCR podem ser uma estratégia para 0 acompanhamento de pacientes em tratamento etiológico ou em risco de reativação clínica.

\subsubsection{Tratamento}

O tratamento da Doença de Chagas é indicado na fase aguda e para os casos de transmissão congênita, por acidente e transplantados ou transfusionados (Von et al., 2007).

Nos casos da doença crônica, o tratamento é recomendado àqueles que adquiriram há menos de dez anos ou aos pacientes imunodeprimidos, nos quais a doença foi reativada (Von et al., 2007).

Os dois principais tratamentos etiológicos utilizam as drogas nitroheterocíclicas benzidonazol e nifurtimox, com efetividade estimada em $60 \%$ dos casos agudos, porém ambas expõem os pacientes a severos efeitos colaterais.

\subsubsection{Estudos de drogas e vacinas contra a doença de Chagas}

Segundo Sanches-Burgos et al. (2007), uma das prioridades acerca do combate à doença é o estudo de novas vacinas, devido a pouca eficácia das já testadas. Os resultados de seus estudos em camundongos, demonstraram que a eficiência das vacinas é dependente do antígeno utilizado e que aquelas contendo DNA dos plasmídios Tc24, TSA-1 e Tc52 induziram ao mais completo controle da doença, com significativa redução da parasitemia, mortalidade, miocardite e acúmulo de parasitos no coração. 


\subsection{Modelo animal e a ciência de animais de laboratório}

\subsubsection{Modelo animal: escolha e importância para os resultados experimentais}

Para buscar conhecimento científico, desde a Grécia antiga o homem utiliza animais em seus experimentos (Frajblat et al., 2006; Passos et al., 2003).

Entreanto, somente no século $X X$, os animais tornaram-se indispensáveis à pesquisa, não só por permitir avanços no conhecimento de mecanismos dos processos vitais, mas também para aperfeiçoamento dos métodos de prevenção, diagnóstico e tratamento de doenças, tanto na medicina humana como na medicina veterinária (Frajblat et al., 2006).

Nos estudos de doenças genéticas humanas, por exemplo, os modelos especiais utilizados permitem estudar a patologia de uma determinada síndrome ao longo do tempo, no desenvolvimento de terapias gênicas ou na descoberta de novos genes, que podem ser o caminho para novos medicamentos (Godard \& Guénet, 1999).

Os mamíferos, especialmente camundongos e ratos, representam mais de $90 \%$ dos animais utilizados, além dos hamsters, cobaios e coelhos, eleitos para o uso na pesquisa em diversas áreas, devido aos seus parâmetros biológicos e suas características particulares (Passos et al., 2003; Magalhães, 2009).

Em levantamentos realizados pela Biblioteca Regional de Medicina incluindo a Medline, Lilacs, Scielo e Biblioteca Cochrane, seis espécies de animais foram apontadas como as mais citadas em trabalhos científicos, por ordem de utilização: ratos, camundongos, coelhos, cães, porcos e os primatas (Fagundes \& Taha, 2004).

\subsubsection{Camundongos utilizados na pesquisa biomédica}

Os camundongos utilizados hoje em pesquisa tiveram sua origem há cerca de 1 milhão de anos, derivados de 4 subespécies do gênero mus: domesticus (oeste europeu); molossinus (Japão); musculus (leste europeu, Rússia e norte da China) e castaneus (oeste da Ásia, sudoeste da Ásia e sul da China). Apesar de diferir entre si quanto a critérios genéticos, estes grupos podem se hibridizar, ao contrário de outros grupos do gênero mus, que muitas vezes 
dividem o mesmo território, mas não se hibridizam em estado natural (Passos et al., 2003; Massironi, 2009).

Recolhidos em cativeiro, esses animais puderam ser acasalados programadamente, permitindo-se obter linhagens com características genéticas diferentes umas das outras. Paralelamente, a boa aceitação por acasalamentos consangüíneos, entre irmãos, permitiu a produção de linhagens homozigotas, denominadas isogênicas ou inbred, que possuem alto grau de homozigosidade. (Passos et al., 2003; Godard \& Guénet, 1999; Magalhães, 2009).

Em geral, o camundongo é o melhor modelo para estudos genéticos e de doenças humanas como, por exemplo, diabetes, doenças renais, obesidade, várias doenças autoimunes e de trato complexo, e também nos estudos do câncer. Fatores como genoma seqüenciado, que possibilita a sua manipulação genética; tamanho pequeno; fácil manuseio; curto ciclo de vida, que permite o acompanhamento de uma determinada doença ao longo do tempo; alta fecundidade e curta gestação além de seu custo relativamente baixo o tornam o modelo preferido quando comparado a outras espécies de laboratório (Ko \& De Luca, 2009; Massironi, 2009).

\subsubsection{Linhagens isogênicas}

Uma linhagem é isogênica quando os organismos são geneticamente idênticos. A similaridade entre os camundongos isogênicos leva à uniformidade fenotípica. O pequeno número de animais necessários para um experimento já torna a análise estatística significante (Massironi, 2009).

As linhagens de camundongos isogênicas são produzidas a partir de acasalamentos entre irmãos por pelo menos vinte gerações, ininterruptamente. Obtém-se daí 98,7\% de todos os loci do genoma em homozigose. Após 40 gerações, 99,98\% de todo o genoma será homozigoto (Massironi, 2009).

\subsubsection{Híbridos F1}

São indivíduos obtidos da primeira geração de um cruzamento entre duas linhagens isogênicas. São uniformes geneticamente, sendo heterozigotos para os loci polimórficos. Por isso, estes animais expressam maior vigor que os seus parentais isogênicos, como resultado da hibridização, assim como possuem maior peso corpóreo, fecundidade, tempo de vida e maior resistência a doenças e a 
manipulação experimental (Massironi, 2009; JAX ${ }^{\circledR}$ Mice Catalog, 2009a).

\subsubsection{Híbridos ou recombinantes F2}

Os indivíduos F2 são obtidos a partir do acasalamento entre irmãos da geração F1. Estes animais não terão uniformidade genética, pois sofrerão recombinação pela mistura randômica dos alelos de ambas as linhagens parentais (JAX ${ }^{\circledR}$ Mice Catalog, 2009a).

\subsubsection{Linhagens co-isogênicas}

São linhagens decorrentes de uma mutação ocorrida em um único gene dentro de uma linhagem isogênica já estabelecida. O gene mutante pode ser mantido em estado de homo ou heterozigose e a linhagem mutante pode ser comparada com a respectiva parental que não sofreu a mutação.

Um exemplo muito conhecido deste modelo é a mutação nude ocorrida em BALB/c.

\subsubsection{Linhagens congênicas}

São linhagens obtidas a partir de modelos co-isogênicos. Representam o produto da transferência do gene mutante da linhagem original, para outra, por meio de acasalamentos programados.

A linhagem original é a co-isogênica e a receptora é a congênica (JAX ${ }^{\circledR}$ Mice Catalog, 2009b).

\subsubsection{Linhagens recombinantes congênicas}

São linhagens obtidas após 2 retro-acasalamentos entre híbridos F1 com uma das linhagens isogênicas parentais, seguidas de cruzamentos consangüíneos por 20 gerações, sem o uso de seleção. Ao final, o genótipo do modelo é composto de $75 \%$ do genoma da linhagem receptora e $25 \%$ da linhagem doadora. Este modelo é bastante utilizado no estudo de doenças multifatoriais e de trato complexo (Demant \& Hart,1986; Weil et al.,1997; JAX ${ }^{\circledR}$ Mice Catalog, 2009c). 


\subsubsection{Linhagens consômicas}

As linhagens consômicas, assim como as congênicas são importantes para a análise de tratos multigênicos, podendo ser usadas para caracterizar um componente fenotípico específico, como a resistência ou susceptibilidade individual (Fortin et al., 2001).

São produzidas por meio de acasalamentos programados e monitoração com marcadores polimórficos de DNA, a partir de duas linhagens isogênicas, uma doadora e outra receptora onde, após várias gerações de backcross e intercross, um dos cromossomos da linhagem doadora é substituído pelo seu homólogo da linhagem receptora. Em todas as gerações de acasalamentos, a progênie necessita ser genotipada, para assegurar que recombinações não ocorram entre o cromossomo doador e o seu correspondente receptor, conforme será descrito no capítulo de material e métodos.

Análises com linhagens consômicas permitem ao pesquisador associar rapidamente um fenótipo a um determinado cromossomo, para o qual o doador e o receptor diferem.

Linhagens consômicas são ferramentas poderosas, podendo ser usadas para acelerar a identificação dos locos de caracteres quantitativos (QTL). A presença do traço de interesse particular em um consômico indica que deve haver pelo menos um QTL nesse cromossomo.

Além disso, consômicos exibindo fenótipos de interesse podem ser usados para a produção, em poucas gerações, de uma série de linhagens congênicas, subdividindo estes cromossomos em seguimentos, e permitindo refinar os locos causativos. Isto é obtido pelo retrocruzamento do consômico com a linhagem receptora, identificando na progênie quais as regiões do cromossomo são associadas com o fenótipo (JAX ${ }^{\circledR}$ Mice Catalog, 2009d).

\subsubsection{Linhagens recombinantes consômicas}

São linhagens obtidas a partir do cruzamento entre as linhagens consômicas, permitindo identificar e/ou avaliar locos de caracteres quantitativos (QTL). Via de regra, estes locos são compostos por grupos de genes distribuídos ao longo do genoma e que juntos, interferem na expressão de características como, por exemplo, níveis de resistência a doenças. Uma vez que nos modelos recombinantes consômicos estes QTLs são dissociados, pode-se averiguar a 
importância das associações no fenômeno estudado.

\subsubsection{Características das linhagens isogênicas de camundongos utilizadas no presente trabalho}

\subsubsection{C57BL/6J}

Referida usualmente como C57 Black, B6, B6J, Black 6 ou C57BL/6J (Figura 3) é a linhagem isogênica de camundongos mais amplamente utilizada em pesquisa e também foi a primeira a ter seu genoma seqüenciado. É um modelo para estudo de muitos tumores e o seu background genético favorece a geração de linhagens consômicas, assim como a expressão de muitas mutações tanto espontâneas como induzidas.

Os camundongos C57BL/6J são usados em estudos de genética e imunologia e também são freqüentemente empregados na produção de camundongos transgênicos.

Suas principais características incluem densidade óssea relativamente baixa, desenvolvem diminuição auditiva em torno dos dez meses de idade, além de serem susceptíveis à obesidade induzida, diabetes tipo dois e aterosclerose e representam um bom modelo para o estudo da epilepsia. Os macrófagos destes animais são resistentes para os efeitos da toxina letal da antraz (Jackson Laboratory, $2010^{8}$ ).

PASSOS, 2003, em seus estudos com infecção experimental com T.cruzi da cepa $\mathrm{Y}$, demonstrou serem os camundongos C57BL/6J resistentes a doses de até $10^{5}$ parasitos $/ \mathrm{ml}$.

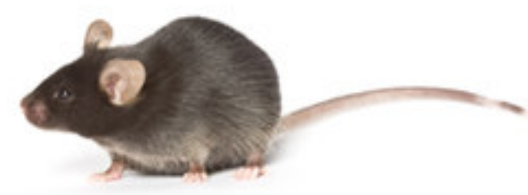

FIGURA 3: Linhagem isogênica C57BL/6J.

FONTE: Jackson Laboratory ${ }^{9}$

\footnotetext{
${ }^{8} \mathrm{http}: / /$ jaxmice.jax.org/strain/000664.html

${ }^{9}$ http://jaxmice.jax.org/images/jaxmicedb/faturedimage/000664_lg.jpg
} 


\subsubsection{A/J}

Desenvolvida por LC Strong em 1921, a linhagem isogênica albina A/J (Figura 4) é a mais usada na pesquisa de câncer e imunologia. Tem alta incidência de adenomas espontâneos e tumores no pulmão e também adenocarcinomas mamários desenvolvidos em fêmeas após vários partos $\left(\right.$ Jackson Laboratory ${ }^{10}$ ). Camundongos $\mathrm{A} / \mathrm{J}$ são resistentes à aterosclerose, diabetes e obesidade. Mantêm baixos níveis de glicose e insulina. São susceptíveis à cortisona, que induz ao palato aberto congênito.

Desenvolvem enfisema pulmonar induzido por cigarro em aproximadamente metade do tempo quando comparados com camundongos C57BL/6.

Também são usados em estudos de distrofia muscular pela inserção do gene Dysferlin por retroacasalamentos (Jackson Laboratory, $2010^{10}$ ).

Passos (2003), em seus estudos com infecção experimental com T.cruzi da cepa $\mathrm{Y}$, demonstrou que, ao contrário dos camundongos C57BL/6, o modelo $\mathrm{A} / \mathrm{J}$ é susceptível e resiste apenas a 10 parasitos $/ \mathrm{ml}$.

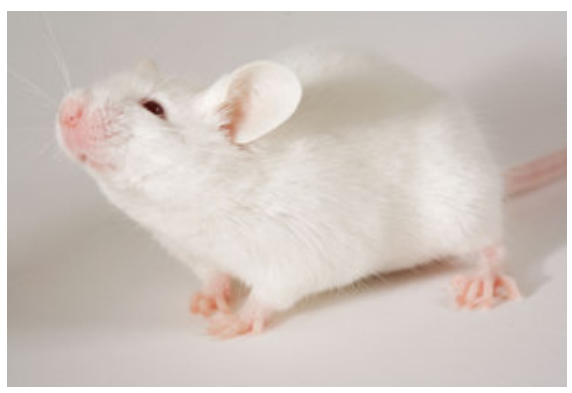

FIGURA 4: Linhagem isogênica A/J.

FONTE: Jackson Laboratory ${ }^{11}$

\subsubsection{CBA/J}

Também desenvolvida por Strong, em 1921, a partir do cruzamento das linhagens Bagg (albino) e DBA, a linhagem isogênica CBA/J (Figura 5) possui pelagem agouti e genótipo $A / A$. É usada em vários propósitos tais como estudos de tireoidite granulada auto-imune experimental (G-EAT). São relativamente

\footnotetext{
${ }^{10} \mathrm{http} / / /$ jaxmice.jax.org/strain/000646.html

${ }^{11}$ http://jaxmice.jax.org/images/jaxmicedb/faturedimage/000646_lg.jpg
} 
resistentes à aterosclerose induzida por dieta e desenvolvem a perda de audição quando senis. Possuem alta freqüência de lesões renais e baixa incidência de tumores mamários. Alguns camundongos CBA/J desenvolvem espontaneamente a síndrome de insuficiência pancreática exócrina (Jackson Laboratory, 2010 ${ }^{12}$ ).

Segundo Passos (2003), o CBA/J possui resistência intermediária à cepa $Y$ do T.cruzi, quando comparado às linhagens C57BL/6J e A/J.

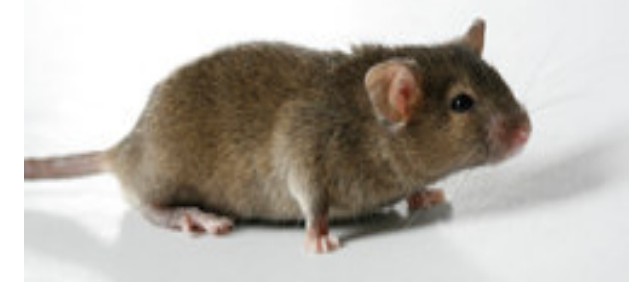

FIGURA 5: Linhagem isogênica CBA/J.

FONTE: Jackson Laboratory ${ }^{13}$

\subsubsection{A ciência de animais de laboratório}

A ciência em animais de laboratório é multidisciplinar e reúne especialistas das mais diferentes áreas. Surgiu com o objetivo de estudar 0 modelo animal, assim como o seu bem estar, sua criação e manipulação, sua saúde e genética entre outros, além de servir de base para outras ciências que utilizam animais (Frajblat et al., 2006; Passos et al., 2003).

Dentre as principais metas da ciência em animais de laboratório estão a produção de animais livres de patógenos específicos (SPF), o desenvolvimento de linhagens especiais para o estudo de diversas doenças humanas, dentre as quais os animais geneticamente modificados, e a monitorização, certificação e criação de linhagens isogênicas, heterogênicas, recombinhantes, congênicas, consômicas e mutantes, entre outras (Davisson, 2006; Passos et al., 2003). Os avanços nos protocolos de pesquisa, aliados à exigência em relação à qualidade dos animais, não apenas em relação ao padrão sanitário, mas também em relação ao padrão genético, fez com que a ciência em animais de laboratório se desenvolvesse, tornando-se cada vez mais uma ciência de ponta, com alta tecnologia envolvida em seus processos (Magalhães, 2009).

\footnotetext{
${ }^{12}$ http://jaxmice.jax.org/strain/000656.html

${ }^{13} \mathrm{http}$ ///jaxmice.jax.org/images/jaxmicedb/faturedimage/000656_lg.jpg
} 
As novas tecnologias, especialmente as instalações com barreiras sanitárias e os alojamentos, permitem a manutenção dos animais em condições controladas, o que favorece o seu bem-estar, assegura sua qualidade, assim como facilita o seu manejo e a sua criação. (Frajblat et al., 2006; Passos et al., 2003). Outro desafio desta ciência é a atenção para a necessidade de uma postura ética ao uso indiscriminado e o desrespeito com os animais. Neste sentido, torna-se cada vez mais imperativo, utilizar-se apenas o número de animais suficiente para a representatividade estatística, considerando-se também imprescindível o acompanhamento dos modelos durante todo o período de investigação, privilegiando-se a adoção de medidas que reduzam a dor, o estresse e favoreçam seu bem-estar (Fagundes \& Taha, 2004).

É também de especial importância a "finalização humanitária", caracterizada como o momento da interrupção, redução ou minimização da dor ou sofrimento animal. Trata-se da morte humanitária, que deve passar por uma abordagem ética, legal e prática (Lapchik \& Mattaraia, 2009).

O conhecimento dos animais quanto a sua biologia, fisiologia, comportamento e necessidades através das pessoas que trabalham diretamente com eles, faz com que saibam como tratá-los de forma correta e com o devido respeito. A credibilidade do resultado da pesquisa depende do bem-estar vivenciado pelo animal, da sensibilidade tanto do pesquisador como do tratador no entendimento de seus sofrimentos e das suas necessidades (Frajblat et al., 2006).

Com o objetivo de sistematizar técnicas humanitárias na experimentação animal, os cientistas ingleses Russel e Burch (1959) descreveram um estudo intitulado "The Principles of Humane Experimental Technique", o qual sintetizava em três palavras o princípio humanitário da experimentação animal, conhecido como "Princípio dos 3 Rs", Replacement Reposição ou Substituição, Reduction - melhor qualidade e resultado com 0 menor número possível de animais e Refinement, redução da incidência ou a gravidade do medo, dor ou desconforto dos animais durante os experimentos (Braga, 2009). 


\subsection{Genética da resistência}

Em humanos, a resistência, assim como a susceptibilidade a doenças compreendem um complexo traço genético. Deste modo, fatores genéticos influenciam diretamente a resposta do hospedeiro à infecção por patógenos.

Para estudar estes mecanismos de resistência ou susceptibilidade a doenças, o uso de modelos animais, especialmente linhagens isogênicas de camundongos têm sido empregados (Malo \& Skamene, 1994).

Em alguns casos a resistência a estes agentes é determinada por um único gene; em outros, pode ser determinada por um complexo e multigênico controle, ou por um grupo de genes ligados, tornando-se necessária a identificação da interação específica entre o agente infeccioso e seu hospedeiro, bem como a trajetória que leva a esta resistência (Trischmann, 1982).

Segundo Trischmann (1982), em organismos não-virais, o locos H-2, que é um importante gene do sistema imune tem mostrado o seu envolvimento na resistência, embora não como um determinante primário, mas talvez numa resposta secundária. Porém, outros genes podem ter influência neste complexo mecanismo.

Powell \& Wassom (1993) confirmaram em seus experimentos que ao menos um gene do MHC (major histocompatibility complex) pode determinar se um camundongo vai viver ou morrer durante a fase aguda da infecção por $T$. cruzi. Porém, a expressão do haplotipo $\mathrm{H}-2 \mathrm{q}$, que foi associado com a resistência em linhagens de camundongos como B10 e DBA/1, na linhagem $\mathrm{C} 3 \mathrm{H}$ foi associado com a susceptibilidade. Estes resultados indicaram não somente genes do MHC ligados a resistência, mas também genes de outras regiões do genoma. Assim a resistência pode ser expressa por ambos: MHC e background genético do hospedeiro.

No caso da Leishmania major, agente etiológico da leishimaniose, a constatação de vários genes influenciando na resposta à infecção em camundongos indicam que a expressão dos componentes da resposta imune e a sua relação com a doença são geneticamente determinadas (Lipoldová et al., 2000). A participação de uma região do cromossomo 9 , juntamente com o locos H-2 já haviam sido indicadas como importante para o controle da infecção experimental por Roberts et al. (1997, 1999), quando os mesmos autores apontaram para outros genes envolvidos com a resistência a este parasita. 
Para a tuberculose, o seu controle genético também é associado a um complexo fenômeno, para os quais vários locos de caracteres quantitativos (QTL) apresentam um forte envolvimento (Sánchez et al., 2003).

Em estudos com a malária em camundongos, causada por $P$. chabaudi, a susceptibilidade é associada com a alta parasitemia (Stevenson \& Lyanga, 1982). Os traços genéticos que regulam os picos de parasitemia, usados para análise de replicação dos parasitos e susceptibilidade para a infecção, assim como o seu controle são complexos, não sendo determinados por um único gene, mas sim por múltiplos genes, os quais refletem a pluralidade de sítios, onde as variações genéticas podem exercer influências no comportamento da doença, atuando na segregação de determinantes genéticos e interferindo na sobrevivência ou mortalidade dos modelos estudados. Os animais $\mathrm{F} 1$ produzidos de duas linhagens de camundongos isogênicas, de fenótipos resistente e susceptível foram mais resistentes que os parentais, sugerindo a resistência como dominante sobre a susceptibilidade, além de uma complementação por parte do parental susceptível ao descendente híbrido (Stevenson \& Lyanga, 1982; Wunderlich et al., 1988; Fortin et al., 1997, 2002; Gundula et al., 2007). Em alguns destes estudos observou-se uma forte influência sexual no controle da doença, onde as fêmeas geralmente apresentaram maior resistência que os machos, segundo os autores, possivelmente por fatores hormonais (Modiano et al., 1996; Wunderlich et al., 1988).

Ainda nos estudos da malária, Gundula et al. (2007) indicaram o cromossomo 10 de camundongos contribuindo substancialmente para o controle no estágio da replicação no sangue do parasita $P$. chabaudi. Este locos foi temporariamente denominado pelos autores como Char9.

Os estudos com T.cruzi apresentados por Trischmann et al. (1982) demonstraram que a heterozigozidade é um fator importante no aumento da resistência. Realizando cruzamentos entre camundongos de linhagens isogênicas de perfis resistentes e susceptíveis, observaram que os descendentes F1 foram sempre mais resistentes do que a linhagem resistente parental, quando desafiados com doses de $10^{4}$ formas do parasita. Também o cruzamento entre duas linhagens susceptíveis apresentou um terço de descendentes F1 resistentes. Com estes resultados, estes autores revelaram ser a resistência ao T.cruzi uma herança dominante. 
Passos et al. (2003), após desafiarem com a cepa $Y$ de T.cruzi, os camundongos $F 2$, produzidos a partir do acasalamento entre irmãos $F 1$, descendentes das linhagens isogênicas C57BL/6 (resistente) e A/J (susceptível), descartaram a resistência como sendo de uma herança monogênica, uma vez que $43 \%$ dos animais infectados com doses de $10^{4}$ formas da cepa $Y$ de T.cruzi foram capazes de controlar a infecção e sobreviveram. Segundo estes autores, o resultado esperado para o caso da doença ser controlada por um único gene seria de cerca de $75 \%$ de sobrevivência.

Ainda em seus experimentos de infecção com T.cruzi, Trischmann (1986) também observou que aqueles animais onde a proliferação do parasita foi mais intensa e rápida eram susceptíveis. Em contrapartida, as linhagens que apresentavam taxas de proliferação mais lenta poderiam ser tanto resistentes quanto susceptíveis, dependendo de eventos no decorrer do curso da infecção, culminando com a eliminação total dos parasitas ou a morte do hospedeiro. Portanto, níveis de parasitemia considerados baixos são indicativos de resistência, herdados dos parentais com perfil dominante, no caso, resistentes.

Wrightsman et al. (1982) nos estudos de infecção em camundongos congênicos, usando a cepa Peru de T.cruzi demonstraram que a sobrevivência pode ser influenciada por vários genes envolvidos com a regulação do nível de parasitemia, localizados fora da região do locos $\mathrm{H}-2$, onde a progênie do híbrido F1 apresentou nível parasitêmico muito abaixo do seu parental LP (baixa parasitemia), indicando um padrão de dominância também para esta característica, e relacionando os baixos níveis parasitêmicos à resistência.

Em 1986, Trischmann demonstrou que o controle na proliferação de parasitos num camundongo normal ocorre tão cedo quanto na complementação do primeiro ciclo da replicação intracelular. Ao realizar infecção experimental numa linhagem RIS (recombinant inbred strain) BXH-2, obtida de C57BL6/J (resistente) e $\mathrm{C} 3 \mathrm{H}$ (susceptível) ele demonstrou que a mesma foi incapaz de controlar a proliferação na fase inicial da infecção, e após 4 a 5 dias a parasitemia destes animais apresentou-se muito mais alta quando comparada a linhagens de camundongos susceptíveis. Seus resultados sugeriram que o breve mecanismo de controle da proliferação do parasita pode ser de importância primária como base para a resistência do hospedeiro. 
Com o propósito de identificar os possíveis genes ou regiões do genoma de camundongos envolvidos com a resistência ao T.congolense, Kemp et al., (1997) utililizaram a técnica da PCR (Polymerase chain reaction), empregando microssatélites polimórficos de DNA, bem como acasalamentos programados. Tais procedimentos permitiram analisar regiões cromossômicas e identificar a participação dos cromossomos 1 e 5 no controle da infecção experimental, bem como sugerir que a resistência é um evento poligênico, com envolvimento de genes fora da região H-2. Iraqi et al. (2000) e Clapcott et al. (2000) em estudos complementares, indicaram outros genes envolvidos com a resistência a este patógeno.

Graefe et al., 2003 indicaram serem os alelos recessivos responsáveis pela susceptibilidade em camundongos isogênicos de algumas linhagens estudadas. Eles identificaram, através da PCR, a participação dos cromossomos 5 e 17 com a susceptibilidade a cepa Toulahuen de T.cruzi.

Passos et al. (2003), trabalhando com linhagens recombinantes (F2), RIS (recombinante isogênica) e RCS (recombinante congênica), derivadas de C57BL/6 (resistente) e A/J (susceptível), e empregando microssatélites polimórfórficos do DNA, identificaram regiões presentes nos cromossomos 7, 11, 14, 17 e 19, importantes para a sobrevivência após a inoculação com altas doses da cepa $Y$ do T. cruzi. Neste estudo, foram consideradas apenas as regiões que apresentaram um valor estatístico superior a 10, na Análise de Quiquadrado $\left(x^{2}\right)$ ao nível de $95 \%$ de significância ( $p>0,05)$, denunciando desvios significativos para o padrão da linhagem isogênica parental de perfil resistente, no caso C57BL/6.

Estes achados, os quais representaram um avanço no entendimento do complexo fenômeno da resistência experimental a Chagas, foram um estímulo para a realização do presente trabalho, no que tange a investigação dos cinco cromossomos apresentados por Passos (2003). A produção de linhagens consômicas e recombinantes consômicas, como posteriormente descritas no capítulo dos métodos, representam uma estratégia para o estudo de cada um destes cromossomos, bem como o seu envolvimento na resistência, quer seja separadamente, ou em interação. 


\subsection{Resposta imune experimental x resistência ao T.cruzi}

A entrada de um microorganismo no corpo induz a uma resposta inflamatória, que é classificada como inflamação aguda. Este processo inflamatório inclui reparação e destruição do agente infeccioso (Huerre \& Gounon, 1996).

Araújo et al. (1998) em experimentos com camundongos selecionados para máxima ou mínima reatividade inflamatória aguda concluíram que, a intensidade da reação imune não específica e a resistência do hospedeiro a infecções causadas por patógenos intracelulares tais como as bactérias Salmonella typhimurium e Listeria monocytogenes estão associadas.

Fiuza et al. (2009), destacaram a importância dos mecanismos imunoregulatórios na prevenção dos efeitos negativos provocados pela estimulação excessiva da resposta imune.

Sant'Anna et al. (1989) demonstraram que linhagens de camundongos considerados bons respondedores para a produção de anticorpos, quando comparados com maus respondedores, foram muito mais susceptíveis para a infecção com Salmonella typhimurium, indicando uma correlação inversa entre a produção de anticorpos e a resistência à infecção. Isto foi demonstrado em populações de híbridos segregantes F2.

Ainda em estudos com camundongos $\mathrm{H}$ e $\mathrm{L}$ (bons e maus respondedores para a produção de anticorpos), Fechio et al. (1999) quando infectaram camundongos com $10^{7}$ amastigotas protozoário L. donovani.por via intravenosa, observaram que os $\mathrm{H}$ foram também mais susceptíveis que os $\mathrm{L}$, apresentando uma maior carga parasitária tanto no fígado quanto no baço.

Estes patógenos intracelulares, como é o caso do T.cruzi, provocam efeitos no sistema imune celular do hospedeiro, que envolvem o recrutamento de células e moléculas efetoras, especialmente os linfócitos T helper (Th-1), que por sua vez induzem a produção de citocinas inflamatórias e regulatórias (Silva et al., 1992; Huerre \& Gounon, 1996; Pelizon et al., 2007). Além disso, tanto o nível como a cinética de produção destas citocinas reguladoras também são fatores importantes para a resistência ao T. cruzi (Eksi et al., 1996).

O modelo imune conhecido da infecção aguda e crônica na doença de Chagas é baseado em animais. Muitas das observações experimentais 
assemelham-se com o limitado número de estudos em humanos (Bhatia et al., 2004).

Nos estudos da resistência à infecção experimental, as principais células e moléculas efetoras que se mostraram relacionadas com a estimulação da imunidade protetora foram as células T CD8+, a resposta T helper (Th-1), INF-Y (interferon gama) e a resposta humoral (Martin \& Tarleton, 2004).

Lipoldová et al. (2000) apresentaram em estudos com a Leishmania major, que tanto a susceptibilidade demonstrada em camundongos da linhagem isogência $B A L B / c$, como a resistência da linhagem isogênica C57BL/6 têm sido atribuídas à baixa representação da resposta Th-1 e a predominância da resposta Th-2, resultando em um aumento na produção de IL-4 e IgE e uma diminuição tanto na produção de INF-y, como na ativação de macrófagos e conseqüentemente na eliminação dos parasitos.

$\mathrm{Na}$ fase aguda da infecção com T.cruzi em camundongos isogênicos, a resistência mostrou-se dependente de IFN- (interferon gama) produzido pelas células NK (natural killer), as quais são ativadas pela citocina IL-12 (interleucina12). O IFN-y ativa os macrófagos para produzirem NO (óxido nítrico), matando as formas amastigotas do parasita que estão dentro das células, ou reduzindo sua replicação (Gazzinelli et al., 1992; Vespa et al., 1994; Cardillo et al., 1996). O IFNY também foi capaz de reverter o curso da infecção fatal in vivo em camundongos altamente susceptíveis (Reed, 1988).

Também o TNF-a (tumoral necrosis factor) indica um segundo sinal de estimulação para a produção de NO na atividade anti-T.cruzi induzida pelos macrófagos ativados por INF-y, mediando assim a função tripanocida (Silva et al., 1992).

Por outro lado, a baixa regulação da citocina Intertleucina 10 (IL-10), cuja fonte são as células T CD4+, de resposta Th-2 e do fator de transformação do crescimento (TGF- $\beta$ ) estão associados com a susceptibilidade à infecção (Silva et al., 1991; Cardillo et al., 1996; Couper et al., 2008), uma vez que ocorre a inibição da ativação dos macrófagos mediados pelo INF-y. Desta forma, estes autores sugerem que o IL-10, citocina produzida durante a infecção pelo $T$. cruzi pode ser um potencial inibidor de produção de INF-y e que a resistência depende do equilíbrio entre o INF-y e IL-10 produzidos na fase aguda da doença (Silva et al., 1992; Cardillo et al., 1996). 
A capacidade do INF-y em limitar a replicação do parasito na fase aguda da infecção pode indicar o seu potencial em dirigir o desenvolvimento de resposta das células $T$ do tipo Th-1, que é predominante na resistência ao $T$. cruzi, enquanto que a resposta das células $T$ do tipo Th-2 caracterizada pelas citocinas IL-4, IL-5, IL-6 e IL-10 está associada com a susceptibilidade (Silva et al., 1992; Cardillo et al., 1996).

Portanto, na resistência à Chagas, as citocinas INF-y e TNF-a possuem papel importante, atuando como reguladoras na produção e expressão de algumas quimiocinas, que agem no controle da infecção (Aliberti et al., 2001).

A produção destas citocinas importantes para a resistência a Chagas também pode variar conforme a idade dos animais, segundo demonstrado nos estudos de Pelizon et al., (2007) com camundongos isogênicos. Animais jovens são mais susceptíveis a infecções porque produzem menos INF-y e IL-12 (Th-1) do que animais adultos. Por outro lado, animais adultos produzem menos IL-4 (Th-2) do que animais jovens e, portanto, controlam melhor a infecção por T.cruzi.

No presente estudo, a avaliação do comportamento de linhagens consômicas e recombinantes consômicas poderá contribuir para o entendimento do complexo mecanismo de resistência à cepa $Y$ do $T$. cruzi, indicando, inclusive, regiões cromossômicas que poderão ser melhor investigadas na busca por genes candidatos responsáveis pela sobrevivência dos animais. 


\section{MATERIAL E MÉTODOS}

\subsection{Material}

\subsubsection{Parasito}

$\mathrm{Na}$ realização dos ensaios foram utilizadas formas tripomastigotas sanguícolas da cepa $\mathrm{Y}$ do Trypanosoma cruzi, mantidas por repiques semanais e ou quinzenais em camundongos da linhagem CBA/Unib.

\subsubsection{Animais}

Para a realização dos experimentos, foram utilizados animais certificados do ponto de vista genético e sanitário, oriundos das Colônias SPF (Specific patogen free) do CEMIB/UNICAMP (Centro Multidisciplinar para Investigação Biológica na Área de Animais de Laboratório/Universidade Estadual de Campinas).

Nos ensaios foram empregadas linhagens de camundongos isogênicos parentais de fenótipo resistente (C57BL/6/Unib) (Figura 3) e susceptível (A/J/Unib) (Figura 4). A partir destes modelos foram produzidas linhagens consômicas para os cromossomos 7, 11, 14, 17 e 19 e recombinantes consômicas.

Também foram utilizados camundongos isogênicos da linhagem CBA/JUnib (Figura 5) para manutenção in vivo do T.cruzi.

Os experimentos foram aprovados pelo CEUA (Comissão de Ética no Uso de Animais) do IPEN - Protocolo no 64 (Anexo 1).

\subsubsection{Reagentes}

Todos os reagentes utilizados foram de qualidade pró-análise e a água purificada em sistema Milli-Q.

\subsection{Métodos}

\subsubsection{Manutenção dos animais}

Todos os camundongos foram mantidos em ambiente controlado, com temperatura de $21^{\circ} \mathrm{C}$, fotoperíodo de $12 \times 12$ horas e em racks ventilados (Alesco), com pressão positiva (Figuras 6 e 7), onde receberam ração autoclavada Nuvitalß e água autoclavada à vontade. 


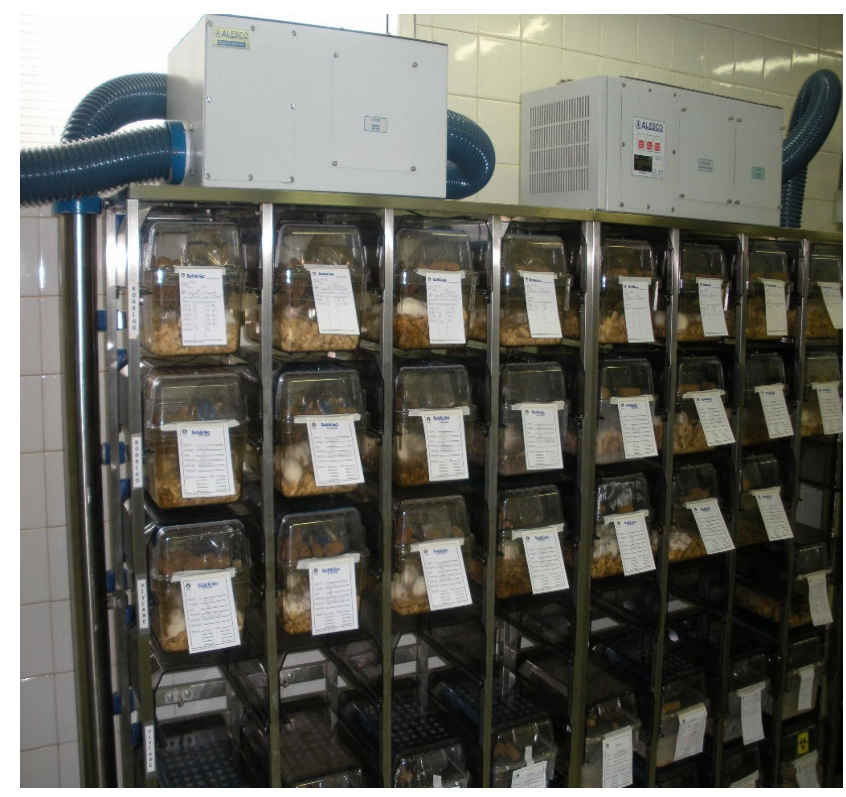

FIGURA 6: Rack ventilada ALESCO $\AA$, com 56 mini-isoladores utilizada para manutenção dos casais em reprodução.

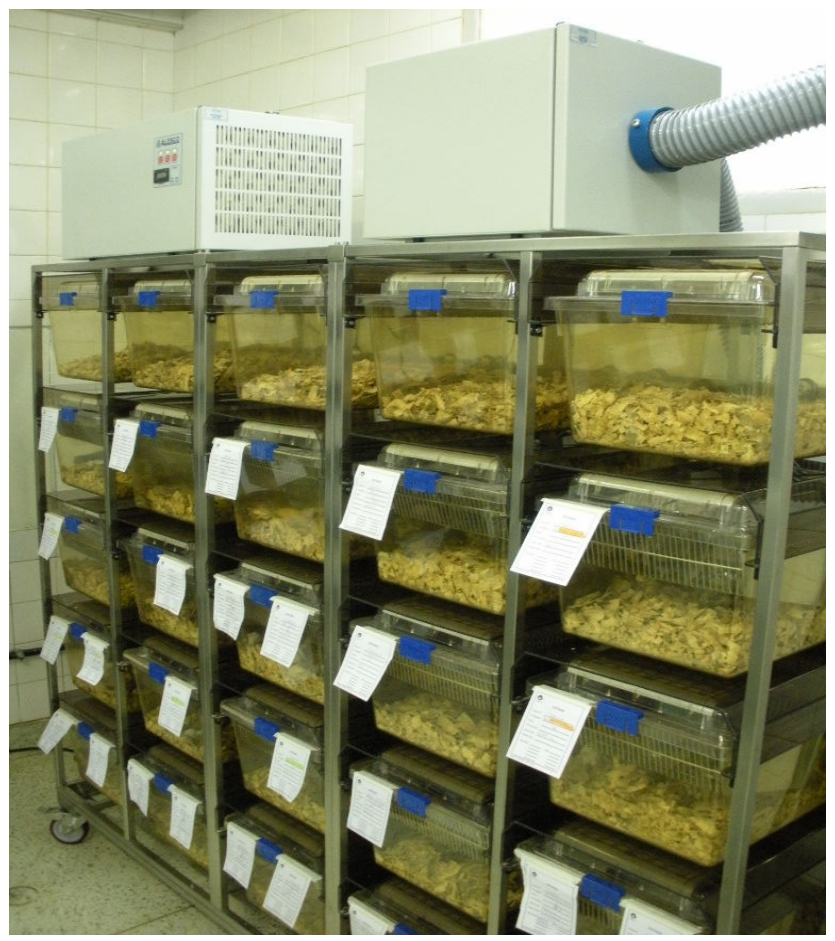

FIGURA 7: Rack ventilada ALESCO $®$, com 25 mini-isoladores com capacidade para até 30 camundongos para manutenção dos estoques de machos e fêmeas dos experimentos. 


\subsubsection{Certificação genética das linhagens parentais com marcadores moleculares de DNA (polimorfismo de microssatélites)}

Em razão da natureza do trabalho e do longo tempo necessário para a produção dos modelos consômicos, as matrizes das linhagens isogênicas parentais C57BL/6/J/Unib e A/J/Unib foram previamente certificadas.

Para tanto, foram feitas análises de DNA, empregando-se 8 marcadores polimórficos de microssatélites e a reação em cadeia da polimerase (PCR) (Kondo et al., 1993).

Como padrões, foram utilizadas amostras de DNA do banco de DNA do CEMIB/UNICAMP, normalmente utilizadas no programa de monitoração genética das colônias do Centro.

As amostras de DNA foram extraídas por precipitação alcoólica (Sambrook et al., 1989) e os marcadores moleculares selecionados estão indicados na tabela 1 abaixo e ilustrados na figura 10.

TABELA 1: Avaliação genética das linhagens parentais isogênicas C57BL/6/Unib, A/JUnib, e da linhagem CBA/JUnib (manutenção in vivo de T. cruzi). Marcadores de microssatélites polimórficos (primers) utilizados: D6mit254 (cromossomo 6), D7mit31 e D7mit301 (cromossomo 7), D14mit165 (cromossomo 14), D15mit246 (cromossomo 15), D17mit88 e D17mit176 (cromossomo 17) e D19mit19 (cromossomo 19).

\begin{tabular}{clcccc}
\hline Cromossomo & Primers & $\begin{array}{c}\text { Posição } \\
\mathrm{cM}\end{array}$ & $\begin{array}{c}\text { A/J } \\
\text { Unib } \\
(\mathrm{pb})\end{array}$ & $\begin{array}{c}\text { C57BL/6 } \\
\text { Unib (pb) }\end{array}$ & $\begin{array}{c}\text { CBA/JUnib } \\
(\mathrm{pb})\end{array}$ \\
\hline 6 & D6mit254 & 57,1 & 117 & 139 & 117 \\
\hline 7 & D7mit31 & 44 & 230 & 245 & 225 \\
\hline 7 & D7mit301 & 46,5 & 131 & 115 & 135 \\
\hline 14 & D14mit165 & 52 & 121 & 135 & 121 \\
\hline 15 & D15mit246 & 60,1 & 132 & 120 & 132 \\
\hline 17 & D17mit88 & 29,5 & 185 & 242 & 185 \\
\hline 17 & D17mit176 & 22,5 & 150 & 174 & 175 \\
\hline 19 & D19mit19 & 26 & 142 & 115 & 115
\end{tabular}

Tabela de exclusão demonstrando a posição do marcador molecular no cromossomo, peso molecular (pb) do DNA das linhagens para cada marcador molecular e polimorfismo entre as linhagens isogênicas parentais. 


\subsubsection{Extração das amostras de DNA por precipitação alcoólica}

Foi retirado um pedaço da orelha ou ponta da cauda de cada animal para a extração das amostras de DNA. Em seguida os tecidos foram colocados em tubos de $1,5 \mathrm{~mL}$ previamente identificados, aos quais foram acrescentados $700 \mu \mathrm{l}$ de tampão de lise e $4 \mu \mathrm{l}$ de proteinase $\mathrm{K}(20 \mathrm{mg} / \mathrm{ml})$. Os tubos permaneceram overnight em banho-maria a $37^{\circ} \mathrm{C}$.

$\mathrm{Na}$ manhã do dia seguinte, foram iniciadas as lavagens com $700 \mu \mathrm{l}$ de uma solução de fenol saturado com Tris/HCL. Os tubos ficaram em agitação lenta por 10 minutos e em seguida centrifugados a $4.536 \mathrm{~g}$ (9000 rpm), por 5 minutos para a coleta do sobrenadante. Após ter sido transferido para outro tubo, o sobrenadante recebeu $700 \mu l$ de clorofórmio e ficou em agitação por 10 minutos para ser novamente centrifugado. Finalmente o sobrenadante foi transferido para outro tubo, ao qual foram acrescentados $70 \mu \mathrm{l}$ de acetato de sódio $3 \mathrm{M}, \mathrm{pH} 7,0$, seguido de uma homogeneização lenta. As amostras foram então colocadas à $20^{\circ} \mathrm{C}$, por 20 minutos, após o que o tubo teve o seu volume completado com etanol gelado, foi homogeneizado e a medusa (DNA precipitado) formada foi recolhida. Este procedimento foi repetido mais uma vez empregando-se etanol a $70 \%$ e em seguida o excesso de álcool foi cuidadosamente retirado, com o auxílio de uma ponteira. Em seguida foram adicionados $500 \mu$ de água deionizada autoclavada em cada tubo. Os tubos foram deixados em estufa a $50^{\circ} \mathrm{C}$ por algumas horas, após o que, foram mantidos em geladeira a $4^{\circ} \mathrm{C}$ até o momento de uso (Sambrook et al. 1989).

\subsection{Produção dos animais recombinantes F2}

Para a primeira etapa da produção dos animais consômicos foram empregadas as linhagens isogênicas parentais C57BL/6/Unib e A/JUnib, com idade entre 8 a 12 semanas.

Inicialmente foram feitos cinco casais de parentais (1:1), sendo as fêmeas da linhagem C57BL/6/Unib e os machos A/JUnib. A progênie (B6CF1/Unib) foi acasalada entre irmãos para a produção dos animais recombinantes F2 (Figura 8). 


\subsubsection{Genotipagem dos animais F2 para seleção dos cromossomos}

O DNA dos animais recombinantes F2 foi extraído conforme indicado em 4.2.2.1 e analisados por PCR, utilizando-se 60 marcadores moleculares polimórficos para as duas linhagens, com o intervalo máximo de $14 \mathrm{cM}$, nos cromossomos 7, 11, 14, 17 e 19 (Tabela 2 e Figura 8).

TABELA 2: Marcadores de microssatélites polimórficos entre as linhagens isogênicas parentais C57BL/6/Unib (resistente) e A/JUnib (susceptível) usados na selecão por PCR (genotipagem), dos F2 para a obtenção das linhagens consômicas.

\begin{tabular}{|c|c|c|c|}
\hline $\begin{array}{l}\text { CROMOSSOMO } 7 \\
(74 \mathrm{cM})\end{array}$ & $\begin{array}{l}\text { CROMOSSOMO } 1 \\
\text { (103 cM) }\end{array}$ & $\begin{array}{l}\text { 1CROMOSSOMO } \\
\text { (69 cM) }\end{array}$ & $\begin{array}{l}\text { 4CROMOSSOMO } 17 \\
(58 \mathrm{cM})\end{array}$ \\
\hline D7MIT190 (2,5 cM) & D11MIT106 (0,25 cM) & & D17MIT164 (4,1 cM) \\
\hline D7MIT117 (11 cM) & D11MIT162 (8 cM) & D14MIT207 (5,5 cM) & D17MIT57 (7,6 cM) \\
\hline D7MIT246 (15 cM) & D11MIT83 (16 cM) & D14MIT133 (10 cM) & D17MIT213 (9,33 cM) \\
\hline D7MIT310 (18 cM) & D11MIT135 (17 cM) & D14MIT214 (19 cM) & D17MIT55 (12,6 cM) \\
\hline D7MIT82 (25 cM) & D11MIT131 (29 cM) & D14MIT113 (25cM) & D17MIT16 (18,15 cM) \\
\hline D7MIT213 (37 cM) & D11MIT242 (31 cM) & D14MIT37 (27,5 cM) & D17MIT233 (20,9 cM) \\
\hline D7MIT301 (46,5 cM) & D11MIT350 $(34,45 \mathrm{cM})$ & D14MIT114 (30 cM) & D17MIT176 (22,5 cM) \\
\hline D7MIT222 (52,6 cM) & D11MIT278 (40 cM) & D14MIT7 (44 cM) & D17MIT66 (24,5 cM) \\
\hline D7MIT238 (53 cM) & D11MIT41 (49 cM) & D14MIT228 (47 cM) & D17MIT88 (29,5 cM) \\
\hline D7MIT255 (60 cM) & D11MIT179 (52 cM) & D14MIT265 (48 cM) & D17MIT139 (30,2 cM) \\
\hline D7MIT186 (64 cM) & D11MIT258 (65 cM) & D14MIT165 (52 cM) & D17MIT20 (34,3 cM) \\
\hline D7MIT332 (65,6 cM) & D11MIT167 (71 cM) & D14MIT266 (62 cM) & D17MIT241 (41,8 cM) \\
\hline D7MIT259 (72,4 cM) & D11MIT48 (77 cM) & & D17MIT142 (42,9 cM) \\
\hline
\end{tabular}

CROMOSSOMO 19

$(55,9 \mathrm{cM})$

D19MIT59 (0,5 cM)

D19MIT16 (15cM)

D19MIT30 (20cM)

D19MIT40 (25 cM)

D19MIT100 (27 cM)

D19MIT119 (27,5 cM)

D19MIT70 (51 cM)

D19MIT34 (53 cM)

D19MIT137 (55,7 cM)

Foram selecionados um total de 60 marcadores de microssatélites polimórficos para as linhagens parentais, com intervalos de no máximo 14 centimorgans e distribuídos ao longo dos 5 cromossomos de interesse $(7,11,14,17$ e 19). No caso do cromossomo 11, o marcador D11 mit48 $(77 \mathrm{cM})$ foi o único, polimórfico entre as linhagens parentais, disponível no mercado, com a posição mais próxima do final do cromossomo $(103 \mathrm{cM})$. Por isso, o intervalo entre $77 \mathrm{cM}$ e $103 \mathrm{cM}$ do cromossomo 11 não foi avaliado. 


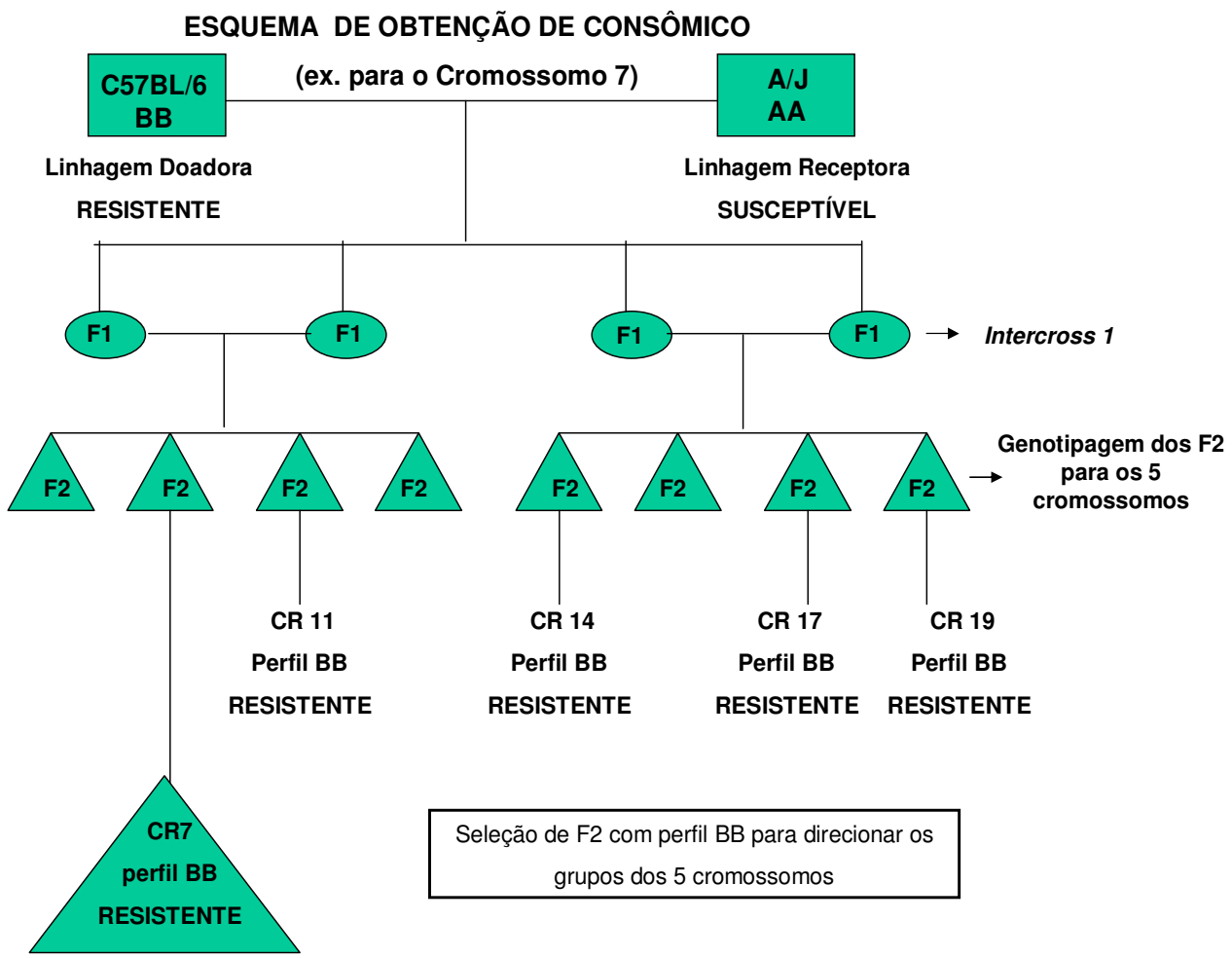

FIGURA 8: Esquema de obtenção de consômico - Produção e seleção de F2 recombinantes:

1) acasalamento entre as linhagens parentais C57BL/6/Unib (doadora), de perfil resistente e A/JUnib (receptora), de perfil susceptível para produção de F1 híbridos; 2) acasalamentos entre $\mathrm{F} 1$ (intercross) para produção de F2 recombinantes; 3) genotipagem dos recombinates F2 para direcionamento do perfil (BB) resistente para os cromossomos 7, 11, 14, 17 e 19 de camundongo. $O$ destaque é um exemplo de F2 recombinante especialmente selecionado para a produção de consômico do cromossomo 7 - CSs7.

Esta seqüência de backcross, seguido de intercross e genotipagem, foi repetida por seis gerações, conforme descrito por Demant \& Hart (1986), com algumas adaptações. Finalmente, os animais homozigotos (BB), filhos do intercross 6, para o cromossomo de interesse (cromossomos 7, 11, 14, 17 e 19) puderam ser utilizados nos testes de infecção experimental. Desde o início dos acasalamentos até esta fase da produção dos consômicos, foram necessários aproximadamente seis anos. 


\subsubsection{Acasalamentos programados para a produção das linhagens consômicas}

Com os animais F2 selecionados, foram feitos acasalamentos em backcross com a linhagem parental A/JUnib (Figura 9).

Foram montados cinco casais para cada um dos cromossomos de interesse.

Toda a progênie, com os animais heterozigotos para o cromossomo de interesse (perfil $A B$ ) foram identificados e acasalados entre si para serem ampliados em sistema de intercross (Figura 9).

Após os nascimentos, os filhos desses intercross foram genotipados e somente os indivíduos homozigotos (BB) para os cromossomos de interesse, foram utilizados em novo acasalamento em sistema de backcross com a linhagem susceptível A/JUnib (Figura 9).

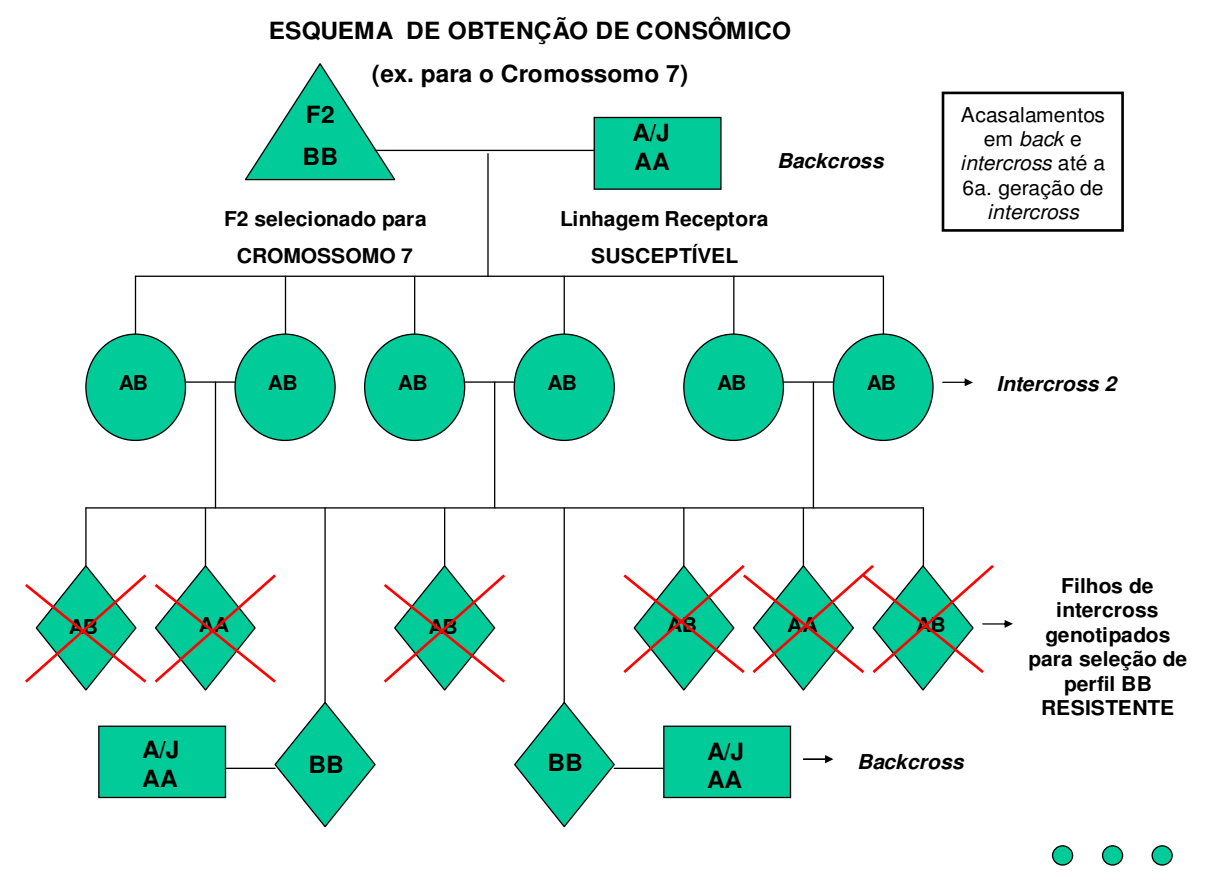

FIGURA 9: Esquema de obtenção de consômico a partir de F2 recombinantes, selecionados por genotipagem, com perfil (BB) resistente nos cromossomos 7, 11, 14, 17 e 19 de camundongo: 1) acasalamentos em backcross dos F2 selecionados com a linhagem A/JUnib receptora, de perfil susceptível; 2) Acasalamentos em intercross, dos descendentes heterozigotos; 3) filhos do intercross genotipados para seleção do perfil (BB) resistente nos cromossomos de interesse; 4) repetições de acasalamentos em backcross com a linhagem A/JUnib 
receptora, de perfil susceptível, seguidos de intercross entre heterozigotos e genotipagem dos descendentes para seleção do perfil resistente até a 6ª geração de intercross.

\subsubsection{Acasalamentos dos animais consômicos para expansão e infecção}

Após a genotipagem para a escolha dos animais originados do sexto intercross, os casais selecionados foram acasalados entre si, segundo o cromossomo de interesse, para expansão desta colônia. A partir desta etapa, os casais foram mantidos e as progênies foram utilizadas nos protocolos de infecção experimental.

\subsubsection{Produção das linhagens recombinantes consômicas de primeira geração pelo cruzamento entre os consômicos}

Após a obtenção das linhagens consômicas, foram produzidas as seguintes linhagens recombinantes consômicas:

A partir do consômico para o cromossomo 7, foram produzidos 4 recombinantes: $7 \times 11 ; 7 \times 14,7 \times 17$ e $7 \times 19$.

A partir do consômico para o cromossomo 11, foram produzidos 3 recombinantes: $11 \times 14,11 \times 17$ e $11 \times 19$.

A partir do consômico para o cromossomo 14, foram produzidos 2 recombinantes: $14 \times 17$ e $14 \times 19$.

A partir do consômico para o cromossomo 17, foi produzido 0 recombinante: $17 \times 19$.

Os nascimentos da primeira geração destes grupos foram utilizados em experimentos de infecção com diferentes doses de tripomastigotas $\left(10^{1}, 10^{2}, 10^{3}\right.$ e $10^{4}$ parasitos $/ \mathrm{mL}$ )

\subsubsection{Formação dos estoques para infecção}

$\mathrm{Na}$ formação dos estoques, os animais desmamados com trinta dias foram marcados com amputação de falange e mantidos, separados por sexo e cromossomo, em racks ventiladas até atingirem a idade de 8 a 12 semanas. 


\subsubsection{Preparação dos grupos experimentais}

Os grupos experimentais foram montados semanalmente de acordo com a disponibilidade de animais. Foram preparados grupos de dez animais, fêmeas e machos, com 8 a 12 semanas de idade, que foram utilizados em cada dose dos ensaios.

\subsection{Manutenção do T. cruzi in vivo}

A cepa $Y$ de Trypanosoma cruzi utilizada em todos os testes de infecção foi mantida in vivo, com repiques semanais ou quinzenais em animais CBA/JUnib, alojados em unidades isoladoras flexíveis, no biotério de experimentação do Laboratório de Controle Sanitário do CEMIB/UNICAMP.

As coletas de sangue foram feitas com os animais anestesiados com halotano, por meio de sangria branca pelo plexo braquial. Após a coleta os animais foram sacrificados por deslocamento cervical.

\subsubsection{T. cruzi sangüícolas para os testes de infecção}

As formas tripomastigotas de $T$. cruzi foram quantificadas pelo método de Brener (1962), onde com auxílio de uma micropipeta, um volume de $5 \mathrm{uL}$ de sangue foi coletado dos camundongos CBA/JUnib do repique, depositado em lâmina e coberto com lamínula para observação em microscópio, com aumento de 400 vezes. Em seguida, o sangue foi diluído às concentrações de $10^{1}, 10^{2}, 10^{3}$ e $10^{4}$ formas de parasito/mL e administrado por via i.p. (intraperitonial) aos animais. Foram inoculados $0,1 \mathrm{~mL} /$ animal às linhagens consômicas para os cromossomos 7(CSs7), 11(CSs11), 14(CSs14), 17(CSs17) e 19(CSs19), bem como para a associação em pares destes cromossomos (linhagens recombinantes consômicas).

\subsection{Determinação das doses discriminatórias e infecção das linhagens parentais C57BL/6/Unib, de fenótipo resistente e A/JUnib, susceptível: grupos controle da infecção}

Segundo Passos (2003), para a determinação da dose discriminatória de T. cruzi sangüícolas, camundongos das linhagens C57BL/6/Unib e A/JUnib foram infectados com diferentes concentrações de parasitos por animal, permitindo 
assim, identificar a dose capaz de separar as populações de animais resistentes e susceptíveis.

Para estes grupos controle, por se tratarem de linhagens isogênicas polares para a resistência à cepa $Y$ de $T$. cruzi, foram considerados resistentes os animais que apresentaram parasitemia por volta do $14^{\circ}$ dia e sobreviveram, por pelo menos 30 dias, após a inoculação com $10^{4}$ tripomastigotas.

\subsubsection{Análise da parasitemia}

A contagem dos parasitos circulantes nos animais foi realizada pelo método de Brener (1962), a partir do início da parasitemia, conforme tabela 3 abaixo. Os animais foram contidos e com auxílio de um bisturi tiveram a ponta da cauda (cerca de $2 \mathrm{~mm}$ ) cortada. Em seguida, a cauda foi ordenhada até que uma gota de sangue (aproximadamente $5 \mathrm{uL}$ ) fosse depositada diretamente em lâmina e coberta com lamínula de 22×22 mm para observação em microscópio.

Todos os animais foram acompanhados para a constatação de infecção, porém, apenas dois animais por grupo foram acompanhados durante toda a parasitemia, em dias alternados, até a sua morte ou ausência de parasitos.

TABELA 3: Início do período de observação da parasitemia, segundo a dose de infecção. Para $10^{1}$ tripomastigotas, contagem no $15^{\circ}$ dia após-infecção; $10^{2}, 12^{\circ}$ dai; $10^{3}, 10^{\circ}$ dai e $10^{4}, 7^{\circ}$ dai, respectivamente.

\begin{tabular}{cc}
\hline DOSE & $\begin{array}{c}\text { INí́CIO DA PARASITEMIA } \\
\text { (dai) }\end{array}$ \\
\hline $10^{1}$ & 15 \\
\hline $10^{2}$ & 12 \\
\hline $10^{3}$ & 10 \\
\hline $\begin{array}{c}10^{4} \\
\text { dai = dia após-infecção }\end{array}$ & 7
\end{tabular}

\subsubsection{Acompanhamento da sobrevivência ou mortalidade}

Após o início da parasitemia, todos os animais foram observados diariamente até a sua morte ou pelo menos até o 50 daí (devido a ocorrência de mortalidade tardia), quando os sobreviventes foram considerados resistentes. Os animais resistentes tiveram uma amostra da orelha retirada para posterior 
extração e análise do DNA. Em seguida os animais foram sacrificados por deslocamento cervical.

\subsection{Registro das colônias: controle e acompanhamento das linhagens e experimentos}

Por se tratar de um experimento com elevada complexidade nos registros e exigente quanto ao acompanhamento dos animais, especial atenção foi dada à documentação.

Para tanto, foram confeccionados mapas genéticos onde foram anotados os resultados da genotipagem para a seleção e acasalamento, e planilhas, onde quaisquer ocorrências observadas nas colônias eram imediatamente documentadas. Todas as informações foram atualizadas diariamente.

Os mapas foram confeccionados na forma de heredogramas com os parentais distribuídos na base, ou raiz e, os descendentes selecionados, distribuídos nas famílias.

Este modelo permitiu o acompanhamento preciso de cada linhagem consômica.

\subsection{Análise estatísitica}

Os resultados da análise de sobrevivência dos animais foram expressos em porcentagem de sobrevivência, considerando o número total de animais inoculados nas diferentes doses.

As análises estatísticas dos grupos foram realizadas pelo software GraphPad InStat V.3. com análise de variância (ANOVA) e os gráficos foram feitos em Microsoft® Excel 2002. 


\section{RESULTADOS}

\subsection{Certificação genética das linhagens parentais com o uso de marcadores} moleculares polimórficos de microssatélites empregando a reação da PCR.

Os resultados obtidos na comparação das amostras parentais com os padrões de DNA (Figura 10) certificaram geneticamente as linhagens C57BL/6/Unib e A/JUnib, indicando que as mesmas poderiam ser utilizadas na produção das linhagens consômicas.

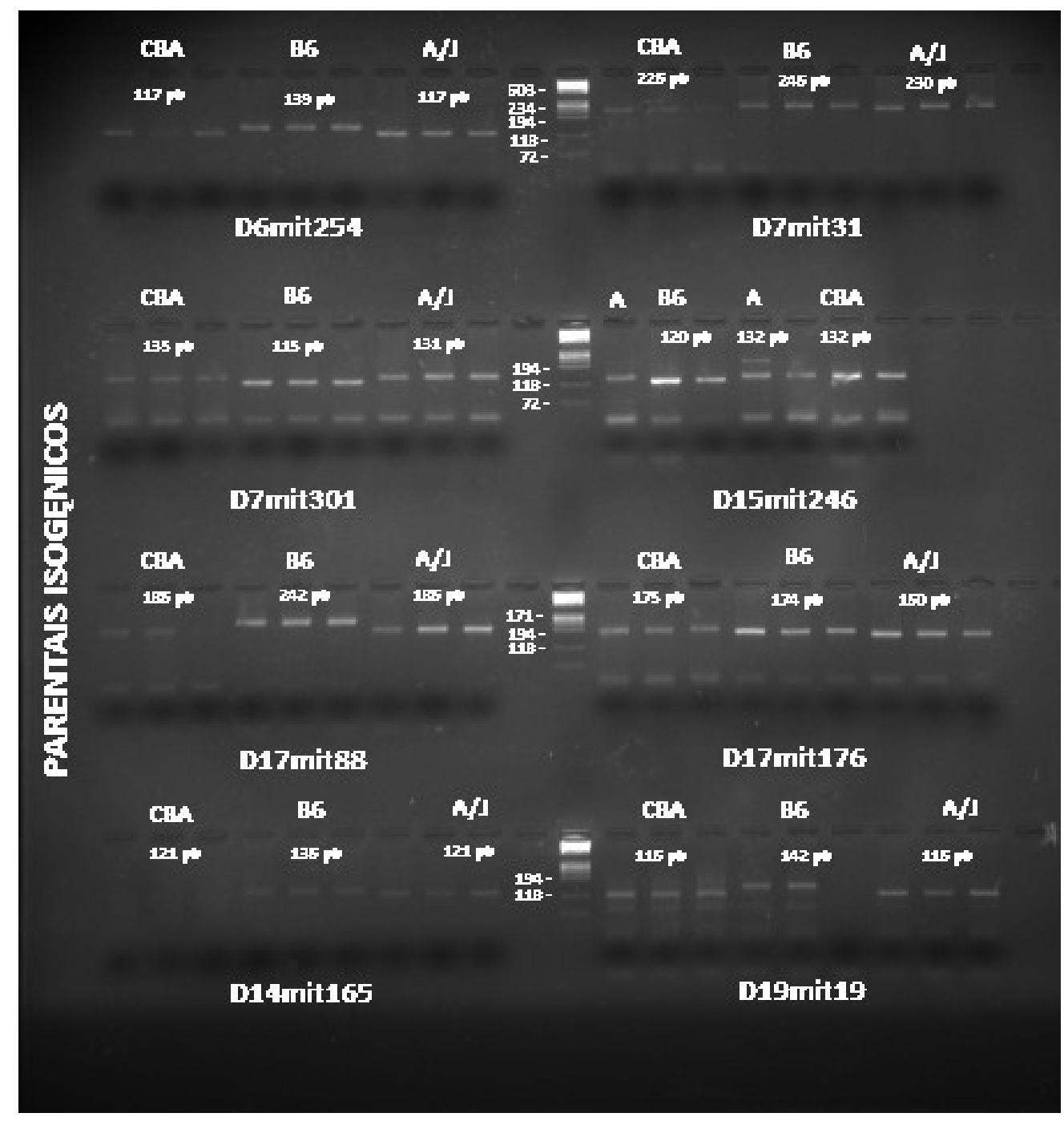

FIGURA 10: Imagem de eletroforese em gel de agarose a $4 \%$ com os resultados da certificação genética das linhagens parentais C57BL/6/Unib (resistente), A/JUnib (susceptível) e CBA/JUnib (manutenção in vivo de $T$. cruzı). Foram testadas 2 amostras de DNA de cada linhagem parental, comparadas com os padrões das linhagens (Banco de DNA CEMIB) nos seguintes primers: D6mit254 (cromossomo 6), D7mit31 e D7mit301 (cromossomo 7), D14mit165 (cromossomo 
14), D15mit246 (cromossomo 15), de D17mit88 e D17mit176 (cromossomo 17) e D19mit19 (cromossomo 19). As amostras e os padrões também foram comparadas com o padrão de peso molecular ( $\phi 174$ - ao centro da imagem) e não apresentaram diferenças de migração, como o esperado para estas linhagens, segundo os pesos moleculares, indicados na imagem.

\subsection{Seleção e acasalamentos programados para produção das linhagens consômicas}

Após os acasalamentos programados alternando-se backcross e intercross, conforme descrito em materiais e métodos, estima-se que os genomas dos indivíduos de cada linhagem consômica apresente uma proporção de aproximadamente $98 \%$ da linhagem isogênica receptora, de fenótipo susceptível (AA) e $2 \%$ da linhagem doadora, resistente (BB), que deverão estar concentrados no cromossomo de interesse em função dos acasalamentos direcionados. O perfil obtido após o 60 Intercross para a formação da linhagem consômica para o cromossomo 17 está indicado na tabela 4 abaixo:

TABELA 4: Resultados da seleção por PCR de machos e fêmeas, descendentes da 6‥ geração de intercross, para os acasalamentos em expansão da linhagem CSs17.

CROMOSSOMO 17 (TOTAL DE $58 \mathrm{cM}$ )

\begin{tabular}{|c|c|c|c|c|c|c|c|c|c|}
\hline \multirow{3}{*}{ PRIMERS } & \multicolumn{3}{|c|}{ Casal (2:1) IC-6 } & \multicolumn{3}{|c|}{$\mathrm{F}^{\circ}$ selecionados } & \multicolumn{2}{|c|}{ Casal IC-6 } & \multirow{2}{*}{ 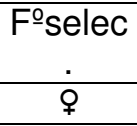 } \\
\hline & $0^{\pi}$ & 인 & ㅇ & $0^{\pi}$ & 우 & $\sigma^{\pi}$ & $0^{\pi}$ & 우 & \\
\hline & 129 & 142 & 108 & 259 & 218 & 5 & 201 & 138 & 2 \\
\hline D17MIT164 (4,1 cM) & $B$ & $B$ & $B$ & $\mathrm{~B}$ & $B$ & $B$ & $B$ & $B$ & $B$ \\
\hline D17MIT213 (9,33 cM) & B & B & B & $B$ & $B$ & $B$ & $\mathrm{~B}$ & B & $B$ \\
\hline D17MIT55 (12,6 cM) & $B$ & $\mathrm{~B}$ & $\mathrm{~B}$ & $\mathrm{~B}$ & $\mathrm{~B}$ & $\mathrm{~B}$ & $\mathrm{~B}$ & $B$ & $\mathrm{~B}$ \\
\hline D17MIT233 (20,9 cM) & $A B$ & $\mathrm{~B}$ & $\mathrm{~B}$ & $\mathrm{~B}$ & $\mathrm{~B}$ & $\mathrm{~B}$ & $\mathrm{~B}$ & $\mathrm{AB}$ & $\mathrm{B}$ \\
\hline D17MIT66 (24,5 cM) & $A B$ & $\mathrm{~B}$ & $\mathrm{~B}$ & $\mathrm{~B}$ & $\mathrm{~B}$ & $\mathrm{~B}$ & $\mathrm{~B}$ & $\mathrm{~B}$ & $\mathrm{~B}$ \\
\hline D17MIT139 (30,2 cM) & $\mathrm{B}$ & $\mathrm{B}$ & $\mathrm{B}$ & $\mathrm{B}$ & $\mathrm{B}$ & $\mathrm{B}$ & $\mathrm{B}$ & $\mathrm{B}$ & $\mathrm{B}$ \\
\hline D17MIT142 (42,9 cM) & $B$ & B & B & B & $\mathrm{B}$ & $B$ & $\mathrm{AB}$ & $\mathrm{B}$ & $B$ \\
\hline D17MIT221 (51,8 cM) & $\mathrm{B}$ & $B$ & $\mathrm{~B}$ & $\mathrm{~B}$ & $\mathrm{~B}$ & B & $\mathrm{AB}$ & $B$ & $\mathrm{~B}$ \\
\hline $\begin{array}{l}\text { Neste grupo de genoti } \\
\text { centimorgans, distribuídos } \\
\text { marcadores moleculares } \\
\text { C57BL/6/Unib (resistente) } \\
\text { Foram selecionados } 2 \text { ma }\end{array}$ & $\begin{array}{l}\text { agem } \\
\text { ao lor } \\
\text { selec } \\
\text { e A/JU }\end{array}$ & $\begin{array}{l}\text { foram } \\
\text { yo dos } \\
\text { onados } \\
\text { b (sus }\end{array}$ & $\begin{array}{l}\text { utilizac } \\
58 \mathrm{cM} \\
\text { foram } \\
\text { eptível }\end{array}$ & $\begin{array}{l}\text { prir } \\
\text { o cror } \\
\text { polim }\end{array}$ & $\begin{array}{l}\text { rs co } \\
\text { ssom } \\
\text { ficos } \\
\text { ram a } \\
218),\end{array}$ & $\begin{array}{l}\text { int } \\
17 \mathrm{~d} \\
\text { ara } \\
\text { leçã }\end{array}$ & $\begin{array}{c}\text { valos } \\
\text { camu }\end{array}$ & $\begin{array}{l}\text { máxim } \\
\text { dongo } \\
\text { agens } \\
\text { padrã }\end{array}$ & $\begin{array}{l}\text { de } 14 \\
\text { Todos os } \\
\text { parentais } \\
\text { desejado. } \\
\text { parentais }\end{array}$ \\
\hline
\end{tabular}


Os resultados obtidos para os outros cromossomos obedeceram este mesmo padrão, onde todos os animais selecionados foram homozigotos para 0 perfil resistente.

Estes resultados demonstram a exclusão do genoma da linhagem susceptível, exceto para o cromossomo de interesse, possibilitando a formação dos casais para a expansão e início dos testes de infecção experimental.

Não foram observados problemas reprodutivos na expansão das linhagens consômicas.

\subsection{Infecção das linhagens parentais de fenótipos resistente e susceptível com T. cruzi: grupos controle da infecção}

Os testes realizados com as diferentes doses de parasitas, inoculados por via intraperitonial, em animais C57BL/6/Unib e A/JUnib, permitiram identificar a dose infectante capaz de discriminar as populações de animais resistentes e susceptíveis, excluindo-se os indivíduos de fenótipo intermediário.

Todos os animais inoculados foram investigados no intervalo compreendido entre o $7^{\circ}$ e $14^{\circ}$ dia após a infecção, e asseguraram a presença do parasita.

Os resultados observados obedeceram ao esperado para estas linhagens, onde os indivíduos que sobrevivem mais do que 30 dias foram considerados resistentes.

A tabela 5 resume os resultados encontrados com a administração de diferentes quantidades de parasitos nas linhagens C57BL/6/Unib e A/JUnib:

TABELA 5: Padrão de resistência observado com as linhagens parentais C57BL/6/Unib e A/JUnib, após a inoculação de diferentes doses $\left(10^{1}\right.$ a $\left.10^{5}\right)$ de tripomastigotas.

\begin{tabular}{lccc}
\hline \multicolumn{1}{c}{ Linhaqem } & Dose & Resistente/Total Desafiado & \% de Resistência \\
\hline \hline \multirow{3}{*}{ C57BL/6/Unib } & $10^{2}$ & $5 / 5$ & 100 \\
\cline { 2 - 4 } & $10^{3}$ & $10 / 10$ & 100 \\
\cline { 2 - 4 } & $10^{4}$ & $16 / 20$ & 80 \\
\hline \hline A/JUnib & $10^{5}$ & $20 / 30$ & 66 \\
\hline & $10^{1}$ & $1 / 20$ & 5 \\
\hline
\end{tabular}

A linhagem C57BL/6/Unib foi submetida a cargas parasitárias crescentes em função de sua maior resistência, enquanto a linhagem A/JUnib, por ser susceptível, recebeu a concentração máxima de $10^{2}$ formas de $T$. cruzi. O inóculo foi administrado por via intraperitonial e o período mínimo de observação dos sobreviventes foi de 30 dias. 
Os resultados confirmaram a existência de uma diferença significativa entre as duas linhagens. A inoculação de $10^{2}$ formas de $T$. cruzi foi capaz de matar todos os indivíduos oriundos da linhagem susceptível e nenhum da resistente.

\subsubsection{Infecção dos animais consômicos com o parasito nas doses de $10^{1}$ a $104 / \mathrm{mL}$}

A tabela 6 a seguir apresenta os resultados obtidos com a infecção experimental com o $T$. cruzi nas doses de $10^{1}, 10^{2}, 10^{3}$ e $10^{4}$ para as cinco linhagens consômicas:

TABELA 6: Resultados da comparação entre machos e fêmeas das linhagens consômicas após infecção com as doses de $10^{1}$ a $10^{4}$ tripomastigotas de T. cruzi.

\begin{tabular}{|c|c|c|c|c|c|c|c|c|c|c|}
\hline \multirow[t]{2}{*}{ CONSÔMICO } & \multirow{2}{*}{$\begin{array}{l}\text { D } \\
0 \\
S \\
E\end{array}$} & \multicolumn{2}{|c|}{$\begin{array}{c}\text { № } \\
\text { animais }\end{array}$} & \multicolumn{2}{|c|}{$\begin{array}{c}\text { № } \\
\text { MORTOS }\end{array}$} & \multicolumn{2}{|c|}{$\begin{array}{c}\text { № } \\
\text { RESISTENTES }\end{array}$} & \multicolumn{3}{|c|}{ \% RESISTÊNCIA } \\
\hline & & $\sigma^{2}$ & 9 & $0^{x}$ & 우 & $0^{x}$ & \% & $0^{\pi}$ & ㅇ & TOTAL \\
\hline 7 & $10^{1}$ & 10 & 10 & 4 & 3 & 6 & 7 & 60 & 70 & 65 \\
\hline 7 & $10^{2}$ & 10 & 10 & 8 & 6 & 2 & 4 & 20 & 40 & 30 \\
\hline 7 & $10^{3}$ & 10 & 10 & 3 & 10 & 7 & 0 & 70 & 0 & 35 \\
\hline 7 & $10^{4}$ & 10 & 10 & 10 & 10 & 0 & 0 & 0 & 0 & 0 \\
\hline 11 & $10^{1}$ & 10 & 10 & 10 & 10 & 0 & 0 & 0 & 0 & 0 \\
\hline 11 & $10^{2}$ & 10 & 10 & 10 & 10 & 0 & 0 & 0 & 0 & 0 \\
\hline 11 & $10^{3}$ & 10 & 10 & 10 & 10 & 0 & 0 & 0 & 0 & 0 \\
\hline 11 & $10^{4}$ & 10 & 10 & 10 & 10 & 0 & 0 & 0 & 0 & 0 \\
\hline 14 & $10^{1}$ & 10 & 10 & 10 & 10 & 0 & 0 & 0 & 0 & 0 \\
\hline 14 & $10^{2}$ & 10 & 10 & 10 & 10 & 0 & 0 & 0 & 0 & 0 \\
\hline 14 & $10^{3}$ & 11 & 9 & 11 & 9 & 0 & 0 & 0 & 0 & 0 \\
\hline 14 & $10^{4}$ & 10 & 10 & 10 & 10 & 0 & 0 & 0 & 0 & 0 \\
\hline 17 & $10^{1}$ & 8 & 12 & 7 & 11 & 1 & 1 & 12 & 8 & 10 \\
\hline 17 & $10^{2}$ & 10 & 10 & 10 & 9 & 0 & 1 & 0 & 10 & 5 \\
\hline 17 & $10^{3}$ & 10 & 10 & 10 & 10 & 0 & 0 & 0 & 0 & 0 \\
\hline 17 & $10^{4}$ & 10 & 10 & 10 & 10 & 0 & 0 & 0 & 0 & 0 \\
\hline 19 & $10^{1}$ & 10 & 10 & 10 & 6 & 0 & 4 & 0 & 40 & 20 \\
\hline 19 & $10^{2}$ & 10 & 10 & 10 & 10 & 0 & 0 & 0 & 0 & 0 \\
\hline 19 & $10^{3}$ & 10 & 10 & 10 & 10 & 0 & 0 & 0 & 0 & 0 \\
\hline 19 & $10^{4}$ & 10 & 10 & 10 & 10 & 0 & 0 & 0 & 0 & 0 \\
\hline
\end{tabular}

A tabela acima demonstra os resultados com a infecção das linhagens consômicas (CSs7, CSs11, CSs14, CSs17 e CSs19). São apresentadas as dose para infecção de 10, 100, 1000 e 10000 tripomastigotas de T.cruzi; o número de machos e fêmeas infectados em cada dose e linhagem; o número de fêmeas e machos mortos após a infecção em cada dose e linhagem; o número de machos e fêmeas resistentes após a infecção em cada dose e linhagem e a porcentagem de resistência por sexo e total para cada dose e linhagem. 
Para avaliação de sobrevivência e mortalidade, foram infectados um total de 400 camundongos, distribuídos em 28 grupos experimentais. Foram testados 40 fêmeas e 40 machos de cada uma das 5 linhagens consômicas nas quatro doses (Tab. 6).

Os animais consômicos para o cromossomo 7 sobreviveram até a dose de $10^{3}$ parasitos enquanto os consômicos para os cromossomos 17 e 19 sobreviveram até a dose de $10^{1}$ parasitos inoculados i.p. Os demais modelos consômicos não sobreviveram às doses utilizadas.

\subsubsection{Comparação da sobrevivência dos consômicos com os parentais resistente e susceptível}

Abaixo são indicados na tabela 7, os comparativos entre os animais consômicos que sobreviveram e as linhagens parentais de fenótipos resistente e susceptível:

TABELA 7: Resultados dos comparativos na sobrevivência observada entre as linhagens consômicas que apresentaram resistência nas doses de $10^{1}$ a $10^{4}$ (CSs7, CSs11, CSs14, CSs17 e CSs19) e as linhagens parentais isogênicas C57BL/6/Unib (resistente), nas doses de $10^{1}$ a $10^{5}$ e A/JUnib (susceptível), na dose de $10^{1}$.

\begin{tabular}{lcccc}
\hline Linhagem & Cromossomo & Dose & $\begin{array}{c}\text { Resistente/Total } \\
\text { Desafiado }\end{array}$ & $\begin{array}{c}\% \text { de } \\
\text { Resistência }\end{array}$ \\
\hline \multirow{2}{*}{ C57BL/6/Unib } & & $10^{2}$ & $5 / 5$ & 100 \\
& & $10^{3}$ & $10 / 10$ & 100 \\
\cline { 2 - 5 } & & $10^{4}$ & $16 / 20$ & 80 \\
\hline \multirow{3}{*}{ A/JUnib } & & $10^{5}$ & $20 / 30$ & 66 \\
\hline \multirow{3}{*}{ Consômicos } & $10^{1}$ & $1 / 20$ & 5 \\
\cline { 2 - 5 } & \multirow{2}{*}{7} & $10^{1}$ & $13 / 20$ & 65 \\
\cline { 2 - 5 } & & $10^{2}$ & $6 / 20$ & 30 \\
\cline { 2 - 5 } & 17 & $10^{3}$ & $7 / 20$ & 35 \\
\cline { 2 - 5 } & 17 & $10^{1}$ & $2 / 20$ & 10 \\
\cline { 2 - 5 } & 19 & $10^{2}$ & $1 / 20$ & 5 \\
\hline & 19 & $10^{1}$ & $4 / 20$ & 20
\end{tabular}

Os resultados demonstram que, a depender da dose, a sobrevivência variou entre $35 \%$ e $65 \%$ para os animais consômicos para o cromossomo 7 ; foi 
entre $5 \%$ e $10 \%$ para o cromossomo 17 e $20 \%$ para o cromossomo 19 . Em todos estes consômicos a resistência foi superior ao parental susceptível.

\subsection{Seleção e acasalamentos programados para produção de animais recombinantes originados de cruzamentos entre consômicos em primeira geração}

Os filhos de primeira geração dos acasalamentos realizados entre as linhagens consômicas, que formaram 10 combinações de linhagens recombinantes consômicas, foram inoculados com as doses crescentes de $10^{1} \mathrm{a}$ $10^{4}$ tripomastigotas de T. cruzi (Tab. 8)

A depender dos resultados obtidos com as doses menores, foram sendo realizadas as infecções, com as doses maiores, perfazendo um total de 560 camundongos infectados, distribuídos em 28 grupos experimentais, conforme os resultados indicados na tabela 8.

As linhagens recombinantes consômicas 7 × 11; 7 × 14; 7 × 17; 7 × 19; 11 x 19 e 17 x 19, apresentaram sobrevivência, dependendo da dose utilizada. Por outro lado, os filhos dos cruzamentos para as linhagens $11 \times 14 ; 11 \times 17$; 14 x 17 e 14 x 19 não sobreviveram à dose mínima de $10^{1}$ tripomastigotas (Tab. 8a e 8b).

TABELA 8a: Resultados da comparação entre machos e fêmeas das linhagens recombinantes consômicas de primeira geração após infecção com as doses de $10^{1}$ a $10^{4}$ tripomastigotas de T. cruzi.

\begin{tabular}{|c|c|c|c|c|c|c|c|c|c|c|}
\hline \multirow[t]{2}{*}{$\begin{array}{l}\text { Recombinantes } \\
\text { de } 1^{\mathrm{a}} \text {. geração }\end{array}$} & \multirow{2}{*}{$\begin{array}{l}D \\
0 \\
S \\
E\end{array}$} & \multicolumn{2}{|c|}{$\begin{array}{c}\text { № } \\
\text { animais }\end{array}$} & \multicolumn{2}{|c|}{$\begin{array}{c}\text { № } \\
\text { MORTOS } \\
\end{array}$} & \multicolumn{2}{|c|}{ RESISTENTES } & \multicolumn{3}{|c|}{ \% RESISTÊNCIA } \\
\hline & & $\sigma^{\pi}$ & ㅇ & $\sigma^{*}$ & q & $\sigma^{*}$ & ? & $\sigma^{*}$ & \& & TOTAL \\
\hline $7 \times 11$ & $10^{1}$ & 15 & 20 & 10 & 15 & 5 & 5 & 33 & 25 & 28 \\
\hline $7 \times 11$ & $10^{2}$ & 18 & 17 & 16 & 15 & 2 & 2 & 11 & 11 & 11 \\
\hline $7 \times 11$ & $10^{3}$ & 12 & 8 & 11 & 8 & 1 & 0 & 8 & 0 & 5 \\
\hline $7 \times 11$ & $10^{4}$ & 5 & 15 & 5 & 15 & 0 & 0 & 0 & 0 & 0 \\
\hline $7 \times 14$ & $10^{1}$ & 6 & 12 & 6 & 4 & 0 & 8 & 0 & 66 & 44 \\
\hline $7 \times 14$ & $10^{2}$ & 10 & 10 & 10 & 7 & 0 & 3 & 0 & 30 & 15 \\
\hline $7 \times 14$ & $10^{3}$ & 12 & 8 & 12 & 8 & 0 & 0 & 0 & 0 & 0 \\
\hline $7 \times 17$ & $10^{1}$ & 10 & 10 & 8 & 9 & 2 & 1 & 20 & 10 & 15 \\
\hline $7 \times 17$ & $10^{2}$ & 10 & 10 & 10 & 10 & 0 & 0 & 0 & 0 & 0 \\
\hline $7 \times 19$ & $10^{1}$ & 9 & 10 & 8 & 3 & 1 & 7 & 11 & 70 & 42 \\
\hline $7 \times 19$ & $10^{2}$ & 10 & 11 & 8 & 6 & 2 & 5 & 20 & 45 & 33 \\
\hline $7 \times 19$ & $10^{3}$ & 10 & 10 & 9 & 6 & 1 & 4 & 10 & 40 & 25 \\
\hline $7 \times 19$ & $10^{4}$ & 10 & 10 & 9 & 10 & 1 & 0 & 10 & 0 & 5 \\
\hline
\end{tabular}


TABELA 8b: Resultados da comparação entre machos e fêmeas das linhagens recombinantes consômicas de primeira geração após infecção com as doses de $10^{1}$ a $10^{4}$ tripomastigotas de $T$. cruzi.

\begin{tabular}{|c|c|c|c|c|c|c|c|c|c|c|}
\hline \multirow[t]{2}{*}{$\begin{array}{l}\text { Recombinantes } \\
\text { de } 1^{a} \text {. geração }\end{array}$} & \multirow{2}{*}{$\begin{array}{l}D \\
O \\
S \\
E\end{array}$} & \multicolumn{2}{|c|}{$\begin{array}{c}\text { № } \\
\text { animais }\end{array}$} & \multicolumn{2}{|c|}{$\begin{array}{c}\text { № } \\
\text { MORTOS }\end{array}$} & \multicolumn{2}{|c|}{ RESISTENTES } & \multicolumn{3}{|c|}{ \% RESISTÊNCIA } \\
\hline & & $0^{\pi}$ & ? & 0 & ? & $\sigma^{*}$ & q & $\sigma^{*}$ & ? & TOTAL \\
\hline $11 \times 14$ & $10^{1}$ & 10 & 10 & 10 & 10 & 0 & 0 & 0 & 0 & 0 \\
\hline $11 \times 14$ & $10^{2}$ & 10 & 9 & 10 & 9 & 0 & 0 & 0 & 0 & 0 \\
\hline $11 \times 14$ & $10^{3}$ & 10 & 10 & 10 & 10 & 0 & 0 & 0 & 0 & 0 \\
\hline $11 \times 17$ & $10^{1}$ & 11 & 9 & 11 & 9 & 0 & 0 & 0 & 0 & 0 \\
\hline $11 \times 17$ & $10^{2}$ & 9 & 11 & 9 & 11 & 0 & 0 & 0 & 0 & 0 \\
\hline $11 \times 19$ & $10^{1}$ & 10 & 10 & 9 & 8 & 1 & 2 & 10 & 20 & 15 \\
\hline $11 \times 19$ & $10^{2}$ & 10 & 10 & 10 & 10 & 0 & 0 & 0 & 0 & 0 \\
\hline $11 \times 19$ & $10^{3}$ & 10 & 10 & 10 & 10 & 0 & 0 & 0 & 0 & 0 \\
\hline $11 \times 19$ & $10^{4}$ & 10 & 10 & 10 & 10 & 0 & 0 & 0 & 0 & 0 \\
\hline $14 \times 17$ & $10^{1}$ & 5 & 10 & 5 & 10 & 0 & 0 & 0 & 0 & 0 \\
\hline $14 \times 17$ & $10^{2}$ & 10 & 10 & 10 & 10 & 0 & 0 & 0 & 0 & 0 \\
\hline $14 \times 19$ & $10^{1}$ & 11 & 10 & 11 & 10 & 0 & 0 & 0 & 0 & 0 \\
\hline $14 \times 19$ & $10^{2}$ & 10 & 10 & 10 & 10 & 0 & 0 & 0 & 0 & 0 \\
\hline $17 \times 19$ & $10^{1}$ & 10 & 11 & 10 & 8 & 0 & 3 & 0 & 27 & 14 \\
\hline $17 \times 19$ & $10^{2}$ & 10 & 10 & 10 & 10 & 0 & 0 & 0 & 0 & 0 \\
\hline
\end{tabular}

As tabelas $8^{\mathrm{a}}$ e $8 \mathrm{~b}$ acima demonstram os resultados com infecção das linhagens recombinantes consômicas de primeira geração $(7 \times 11,7 \times 14,7 \times 17,7 \times 19,11 \times 14,11 \times 17,11 \times 19,14 \times 17,14 \times 19$ e 17x19). São apresentadas as doses para infecção de 10, 100, 1000 e 10000 tripomastigotas de T.cruzi; o número de machos e fêmeas infectados em cada dose e linhagem; o número de fêmeas e machos mortos após a infecção em cada dose e linhagem; o número de machos e fêmeas resistentes após a infecção em cada dose e linhagem e a porcentagem de resistência por sexo e total para cada dose e linhagem.

\subsubsection{Comparação da sobrevivência entre os filhos de primeira geração dos consômicos com os parentais de fenótipos resistente e susceptível}

$\mathrm{Na}$ tabela 9 abaixo, estão indicados os comparativos na sobrevivência observada entre os animais consômicos de primeira geração que sobreviveram e as linhagens parentais de fenótipos resistente e susceptível: 
TABELA 9: Resultados dos comparativos na sobrevivência observada entre as linhagens recombinantes consômicas de primeira geração que apresentaram resistência nas doses de $10^{1}$ a $10^{4}(7 \times 11,7 \times 14,7 \times 17,7 \times 19,11 \times 19$ e 17x19) e as linhagens parentais isogênicas C57BL/6/Unib (resistente), nas doses de $10^{1}$ a $10^{5}$ e A/JUnib (susceptível), na dose de $10^{1}$.

\begin{tabular}{|c|c|c|c|c|}
\hline Linhagem & Cromossomo & Dose & $\begin{array}{l}\text { Resistente/Tota } \\
\text { I Desafiado }\end{array}$ & $\begin{array}{c}\% \text { de } \\
\text { Resistência }\end{array}$ \\
\hline \multirow{4}{*}{ C57BL/6/Unib } & & $10^{2}$ & $5 / 5$ & 100 \\
\hline & & $10^{3}$ & $10 / 10$ & 100 \\
\hline & & $10^{4}$ & $16 / 20$ & 80 \\
\hline & & $10^{5}$ & $20 / 30$ & 66 \\
\hline \multirow[t]{4}{*}{ A/JUnib } & & $10^{1}$ & $1 / 20$ & 5 \\
\hline & & $10^{1}$ & 10/35 & 28 \\
\hline & $7 \times 11$ & $10^{2}$ & $4 / 33$ & 11 \\
\hline & & $10^{3}$ & $1 / 20$ & 5 \\
\hline \multirow{9}{*}{$\begin{array}{l}\text { Recombinantes } \\
\text { (Filhos de 10 } \\
\text { geração) }\end{array}$} & & $10^{1}$ & $8 / 18$ & 44 \\
\hline & $7 \times 14$ & $10^{2}$ & $3 / 20$ & 15 \\
\hline & $7 \times 17$ & $10^{1}$ & $3 / 20$ & 15 \\
\hline & $7 \times 19$ & $10^{1}$ & $8 / 19$ & 42 \\
\hline & $7 \times 19$ & $10^{2}$ & $7 / 21$ & 33 \\
\hline & $7 \times 19$ & $10^{3}$ & $5 / 20$ & 25 \\
\hline & $7 \times 19$ & $10^{4}$ & $1 / 20$ & 5 \\
\hline & $11 \times 19$ & $10^{1}$ & $3 / 20$ & 15 \\
\hline & $17 \times 19$ & $10^{1}$ & $3 / 21$ & 14 \\
\hline
\end{tabular}

Os resultados demonstram que, a depender da dose, a sobrevivência variou entre $5 \%$ e $28 \%$ para a associação entre os cromossomos 7 e 11; entre $15 \%$ e $44 \%$ para os cromossomos 7 e 14; 15\% para os cromossomos 7 e 17; entre $5 \%$ e $42 \%$ para os cromossomos 7 e 19 e foi de $15 \%$ para os cromossomos 11 e 19 e 17 e 19.

Estes resultados demonstram que nestas associações, a resistência foi superior àquela observada no parental de fenótipo susceptível.

\subsection{Análise da parasitemia}

Com relação a parasitemia das linhagens consômicas infectadas, os gráficos das figuras 11 a 15 abaixo, demonstram o comportamento observado segundo as doses administradas: 


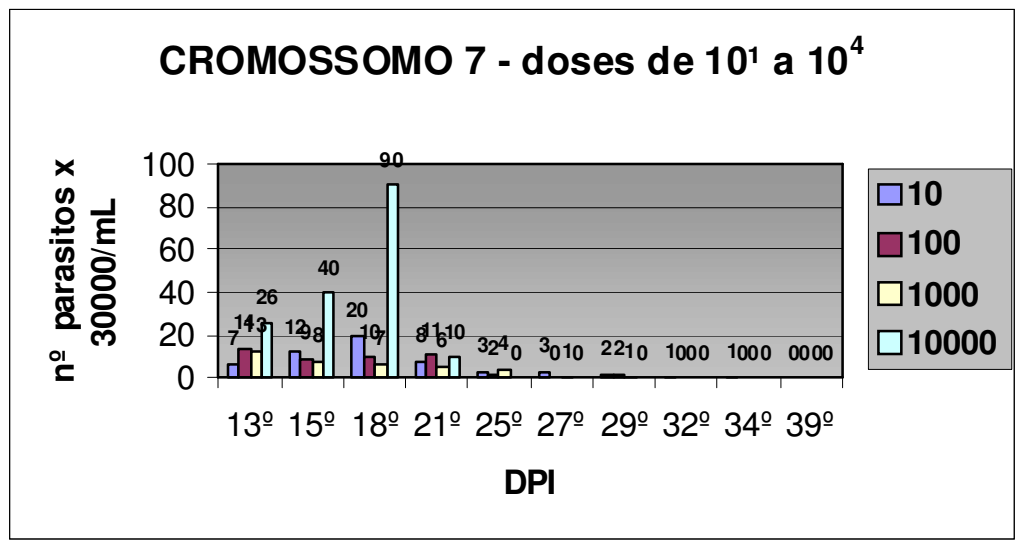

FIGURA 11: Diferenças de parasitemia ( $n^{\circ}$ de parasitos $\times 30000$-fator de correção) na linhagem consômica CSs7 com as doses de $10^{1}$ a $10^{4}$ tripomastigotas de $T$. cruzi, no período do $13^{\circ}$ ao $39^{\circ}$ dia após infecção (dpi).

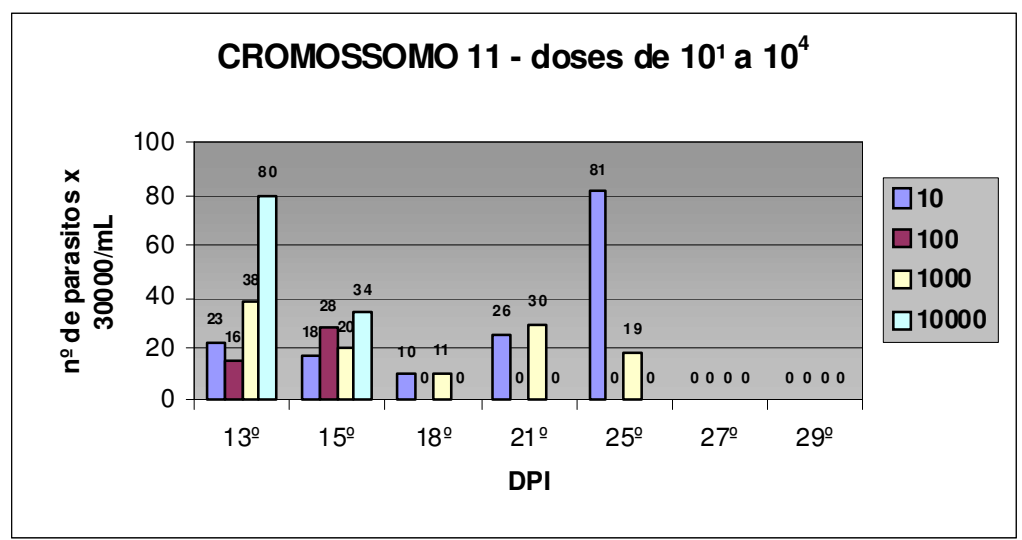

FIGURA 12: Diferenças de parasitemia ( $n^{\circ}$ de parasitos $\times 30000$-fator de correção) na linhagem consômica CSs11 com as doses de $10^{1}$ a $10^{4}$ tripomastigotas de $T$. cruzi, no período do $13^{\circ}$ ao $29^{\circ}$ dia após infecção (dpi). 


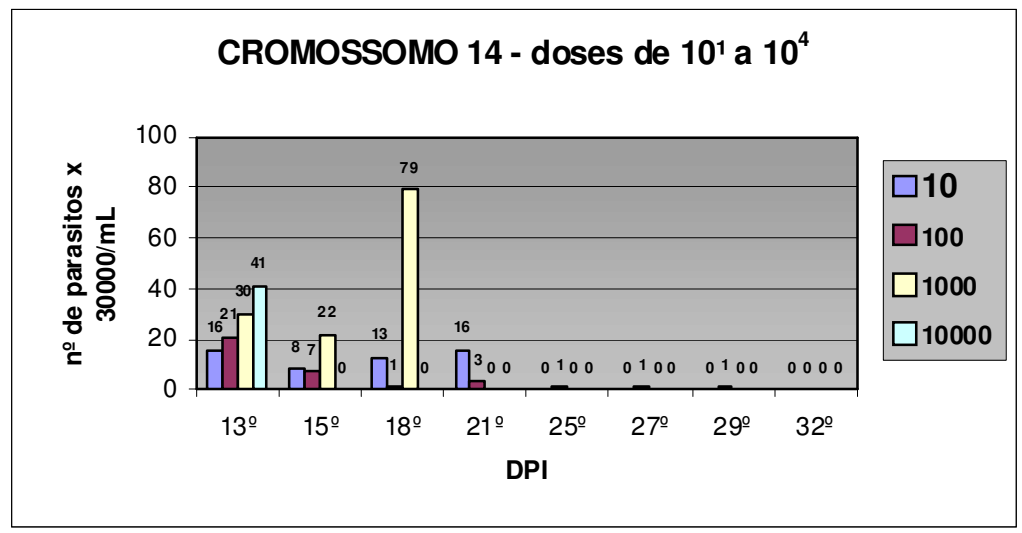

FIGURA 13: Diferenças de parasitemia (no de parasitos $\times 30000$-fator de correção) na linhagem consômica CSs14 com as doses de $10^{1}$ a $10^{4}$ tripomastigotas de $T$. cruzi, no período do $13^{\circ}$ ao $32^{\circ}$ dia após infecção (dpi).

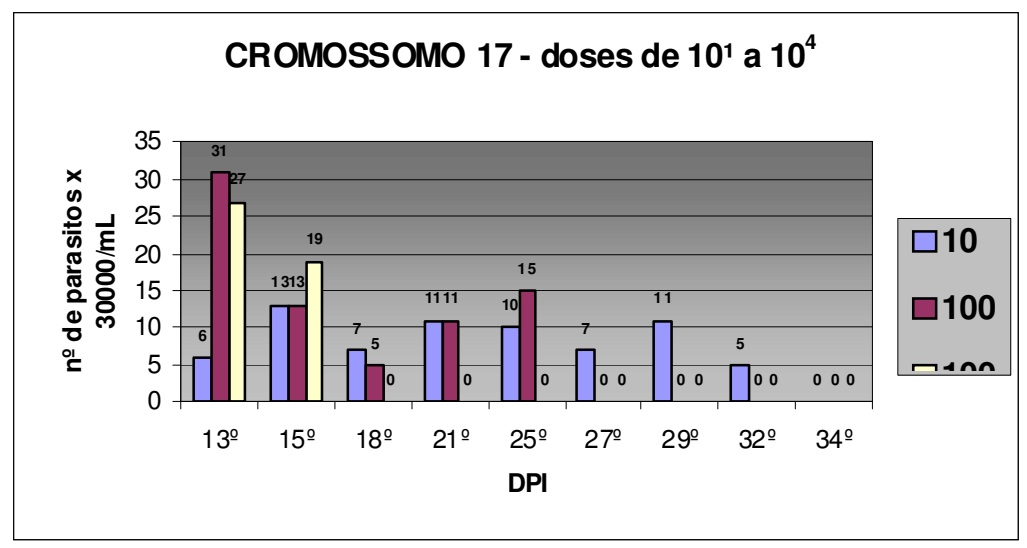

FIGURA 14: Diferenças de parasitemia (no de parasitos $\times$ 30000-fator de correção) na linhagem consômica CSs17 com as doses de $10^{1}$ a $10^{4}$ tripomastigotas de $T$. cruzi, no período do $13^{\circ}$ ao $34^{\circ}$ dia após infecção (dpi). 


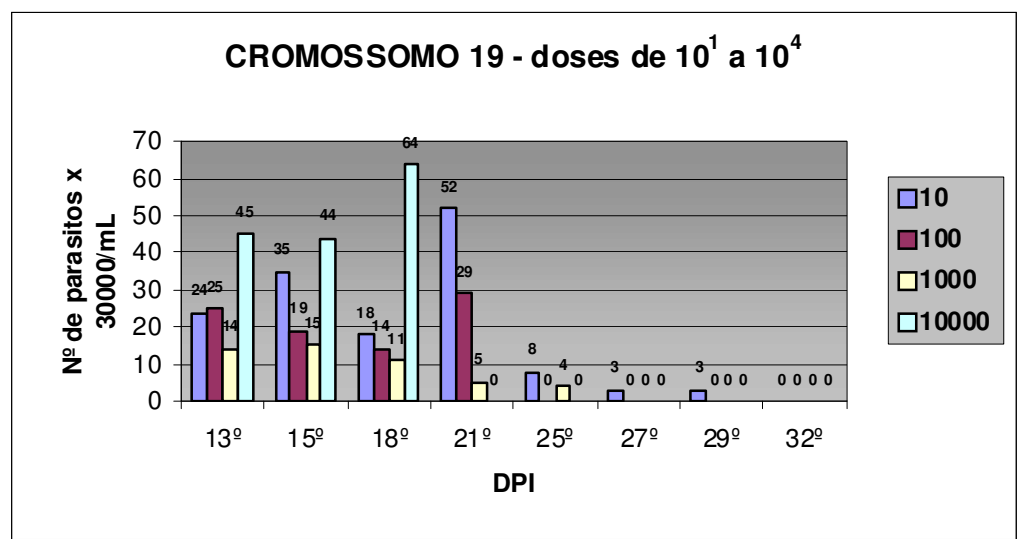

FIGURA 15: Diferenças de parasitemia ( $n^{\circ}$ de parasitos $\times 30000$-fator de correção) na linhagem consômica CSs19 com as doses de $10^{1}$ a $10^{4}$ tripomastigotas de $T$. cruzi, no período do $13^{\circ}$ ao $32^{\circ}$ dia após infecção (dpi).

Os gráficos das figuras 11 a 15 acima apontam a curva parasitêmica dos animais consômicos para os cromossomos $7,11,14,17$ e 19 nas dose de $10^{1}$ a $10^{4}$, sem distinção de sexo e representada pela média entre os animais cuja parasitemia foi acompanhada até a morte ou ausência de parasitos na circulação sangüínea.

A parasitemia apresentou diferenças não só quanto à dose, mas também entre as cinco linhagens de consômicos, como mostram os gráficos das figuras 16 a 19, a seguir:

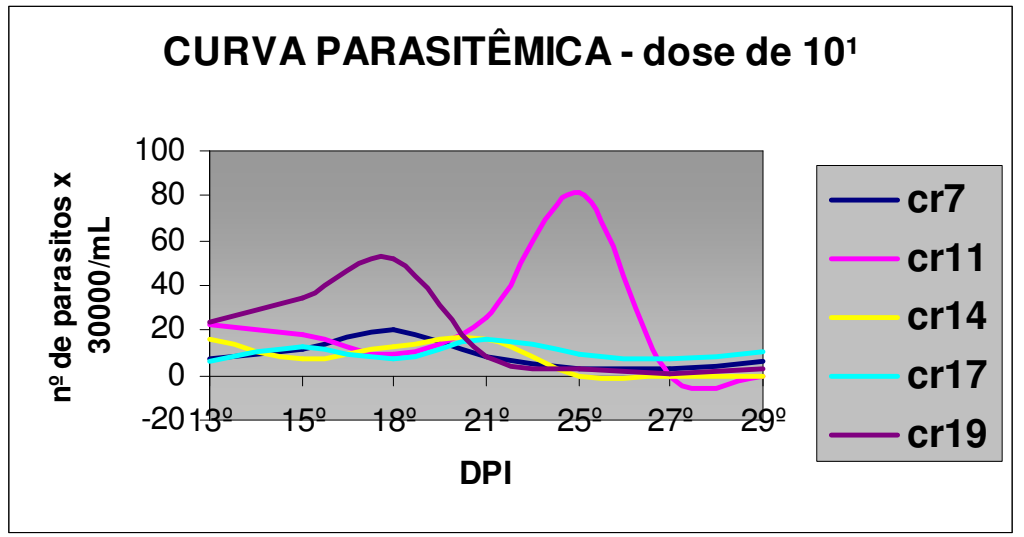

FIGURA 16: Curva para comparação entre o número de parasitos circulantes (multiplicado pelo fator de correção de 30000) apresentados nas linhagens consômicas CSs7, CSs11, CSs14, CSs17 e CSs19, com a dose de 10 tripomastigotas de $T$. cruzi, no período do $13^{\circ}$ ao $29^{\circ}$ dia após infecção (dpi). 


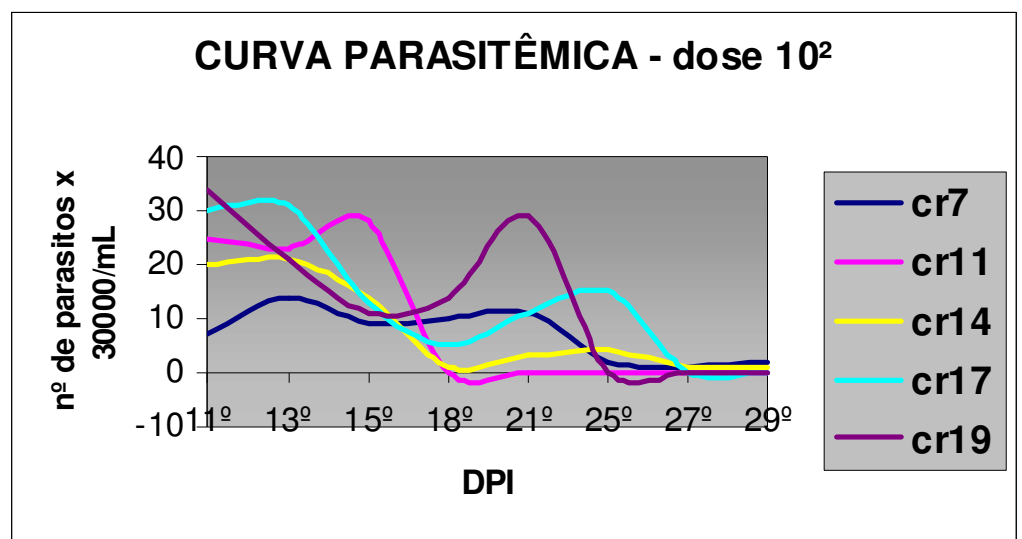

FIGURA 17: Curva para comparação entre o número de parasitos circulantes (multiplicado pelo fator de correção de 30000) apresentados nas linhagens consômicas CSs7, CSs11, CSs14, CSs17 e CSs19, com a dose de 100 tripomastigotas de $T$. cruzi, no período do $11^{\circ}$ ao $29^{\circ}$ dia após infecção (dpi).

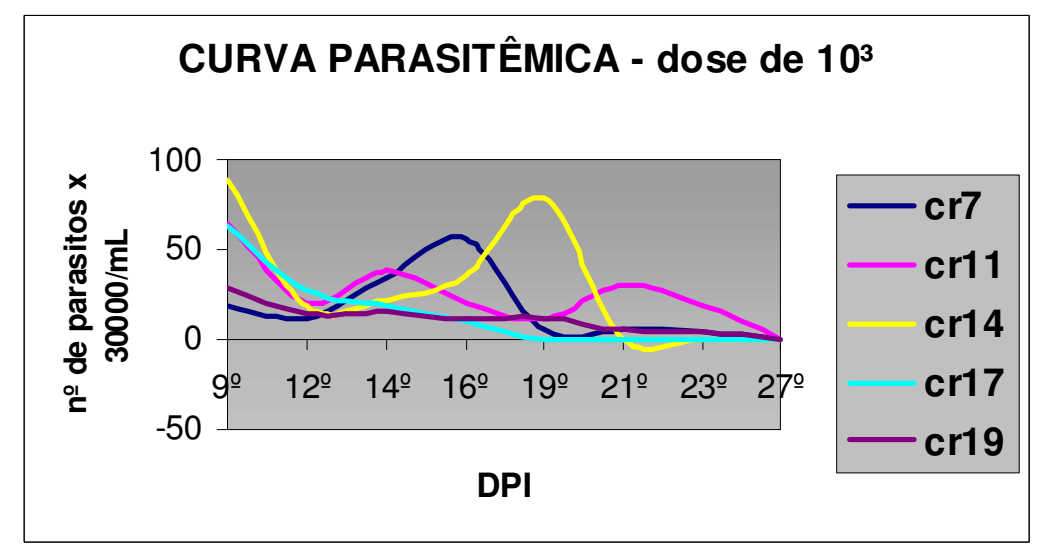

FIGURA 18: Curva para comparação entre o número de parasitos circulantes (multiplicado pelo fator de correção de 30000) apresentados nas linhagens consômicas CSs7, CSs11, CSs14, CSs17 e CSs19, com a dose de 1000 tripomastigotas de $T$. cruzi, no período do 9ำ ao 27ํㅡㄹa após infecção (dpi). 


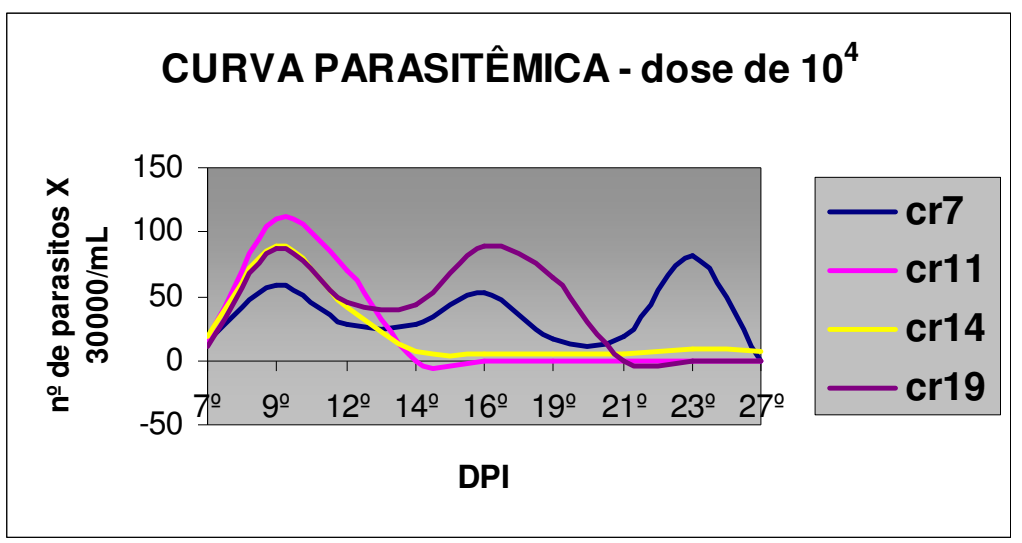

FIGURA 19: Curva para comparação entre o número de parasitos circulantes (multiplicado pelo fator de correção de 30000) apresentados nas linhagens consômicas CSs7, CSs11, CSs14, CSs17 e CSs19, com a dose de 10000 tripomastigotas de $T$. cruzi, no período do $7^{\circ}$ ao $27^{\circ}$ dia após infecção (dpi).

Os gráficos das figuras 16 a 19 acima apontam as diferenças de parasitemia nos animais consômicos para os cromossomos 7, 11, 1417 e 19 frente às doses de $10^{1}$ a $10^{4}$, sem distinção de sexo. Os números representam a média entre os animais cuja parasitemia foi acompanhada até a morte ou ausência de parasitos na circulação sangüínea.

\subsection{Períodos de mortalidade}

Nas tabelas 10, 11 e 12 estão indicados os períodos de mortalidade dos grupos de controles positivos da infecção, dos consômicos e dos cruzamentos entre consômicos de primeira geração:

TABELA 10: Período de mortalidade observado após infecção da linhagem isogênica parental susceptível A/JUnib, usada como controle positivo em todos os experimentos nas doses de $10^{1}$ a $10^{4}$ tripomastigotas de $T$. cruzi.

\begin{tabular}{cc}
\hline DOSE & $\begin{array}{c}\text { CONTROLE POSITIVO } \\
\text { A/JUnib }\end{array}$ \\
\hline $\mathbf{1 0}^{\mathbf{1}}$ & $19-37^{\circ} \mathrm{dpi}$ \\
\hline $\mathbf{1 0}^{2}$ & $15-32^{\circ} \mathrm{dpi}$ \\
\hline $\mathbf{1 0}^{3}$ & $12-30^{\circ} \mathrm{dpi}$ \\
\hline $\mathbf{1 0}^{4}$ & $12-21^{\circ} \mathrm{dpi}$
\end{tabular}


TABELA11: Período de mortalidade observado nos grupos experimentais de infecção das linhagens consômicas CSs7, CSs11, CSs14, CSs17 e CS19 nas doses de $10^{1}$ a $10^{4}$ tripomastigotas de $T$. cruzi.

\begin{tabular}{|c|c|c|c|c|}
\hline \multirow[t]{2}{*}{ CONSÔMICOS } & \multicolumn{4}{|c|}{ DOSES } \\
\hline & $10^{1}$ & $10^{2}$ & $10^{3}$ & $10^{4}$ \\
\hline CR 7 & $26-36^{\circ} \mathrm{dpi}$ & $25-40^{\circ} \mathrm{dpi}$ & $17-34^{\circ} \mathrm{dpi}$ & $14-40^{\circ} \mathrm{dpi}$ \\
\hline CR 11 & 19-27이 & $15-25^{\circ} \mathrm{dpi}$ & $16-26^{\circ} \mathrm{dpi}$ & $12-20^{\circ} \mathrm{dpi}$ \\
\hline CR14 & 17-20ㅇi & 19-40º̂pi & 14-20ㅇi & $12-15^{\circ} \mathrm{dpi}$ \\
\hline CR17 & 19-35ㅇi & $15-40^{\circ} \mathrm{dpi}$ & 15-26이 & $\mathrm{N} / \mathrm{T}^{* *}$ \\
\hline CR 19 & $19-33^{\circ} \mathrm{dpi}$ & $18-36^{\circ} \mathrm{dpi}$ & $16-34^{\circ} \mathrm{dpi}$ & $14-20^{\circ} \mathrm{dpi}$ \\
\hline
\end{tabular}

TABELA12: Período de mortalidade observado nos grupos experimentais de infecção das linhagens recombinantes consômicas de primeira geração nas doses de 101 a 104 tripomastigotas de T. cruzi.

\begin{tabular}{|c|c|c|c|c|}
\hline \multirow{2}{*}{$\begin{array}{l}\text { Cruzamentos entre } \\
\text { consômicos de } 1^{\mathrm{a}} \text {. geração }\end{array}$} & \multicolumn{4}{|c|}{ DOSES } \\
\hline & $10^{1}$ & $10^{2}$ & $10^{3}$ & $10^{4}$ \\
\hline $7 \times 11$ & $20-39^{\circ} \mathrm{dpi}$ & $18-40^{\circ} \mathrm{dpi}$ & 19-27ㅇpi & $19-21^{\circ} \mathrm{dpi}$ \\
\hline $7 \times 14$ & $21-37^{\circ} \mathrm{dpi}$ & $21-35^{\circ} \mathrm{dpi}$ & 19-33ㅇi & $\mathrm{N} / \mathrm{T}$ \\
\hline $7 \times 17$ & $19-39^{\circ} \mathrm{dpi}$ & $20-34^{\circ} \mathrm{dpi}$ & $\mathrm{N} / \mathrm{T}^{* *}$ & $\mathrm{~N} / \mathrm{T}$ \\
\hline $7 \times 19$ & $19-33^{\circ} \mathrm{dpi}$ & $21-39^{\circ} \mathrm{dpi}$ & $22-40^{\circ} \mathrm{dpi}$ & $16-21^{\circ} \mathrm{dpi}$ \\
\hline $11 \times 14$ & $19-23^{\circ} \mathrm{dpi}$ & $17-21^{\circ} \mathrm{dpi}$ & $15-19^{\circ} \mathrm{dpi}$ & $\mathrm{N} / \mathrm{T}$ \\
\hline $11 \times 17$ & $18-25^{\circ} \mathrm{dpi}$ & 18-23ㅇpi & $\mathrm{N} / \mathrm{T}$ & $\mathrm{N} / \mathrm{T}$ \\
\hline $11 \times 19$ & $16-40^{\circ} \mathrm{dpi}$ & $16-32^{\circ} \mathrm{dpi}$ & 16-27이 & 12-19ㅇi \\
\hline $14 \times 17$ & $19-37^{\circ} \mathrm{dpi}$ & $18-33^{\circ} \mathrm{dpi}$ & $\mathrm{N} / \mathrm{T}$ & $\mathrm{N} / \mathrm{T}$ \\
\hline $14 \times 19$ & $19-40^{\circ} \mathrm{dpi}$ & 14-26ㅇpi & $\mathrm{N} / \mathrm{T}$ & $\mathrm{N} / \mathrm{T}$ \\
\hline $\begin{array}{l}17 \times 19 \\
\text { ão testado }\end{array}$ & $26-42^{\circ} \mathrm{dpi}$ & 19-30ㅇpi & $\mathrm{N} / \mathrm{T}$ & $\mathrm{N} / \mathrm{T}$ \\
\hline
\end{tabular}

\subsection{Animais resistentes}

Em razão de se observar mortalidade tardia em diversos grupos investigados, adotou-se como critério, que seriam considerados resistentes apenas os animais que sobrevivessem a um período igual ou superior a 50 dias após a infecção. Os gráficos das figuras 20 e 21, a seguir, apresentam os resultados observados com a sobrevivência dos animais neste período: 


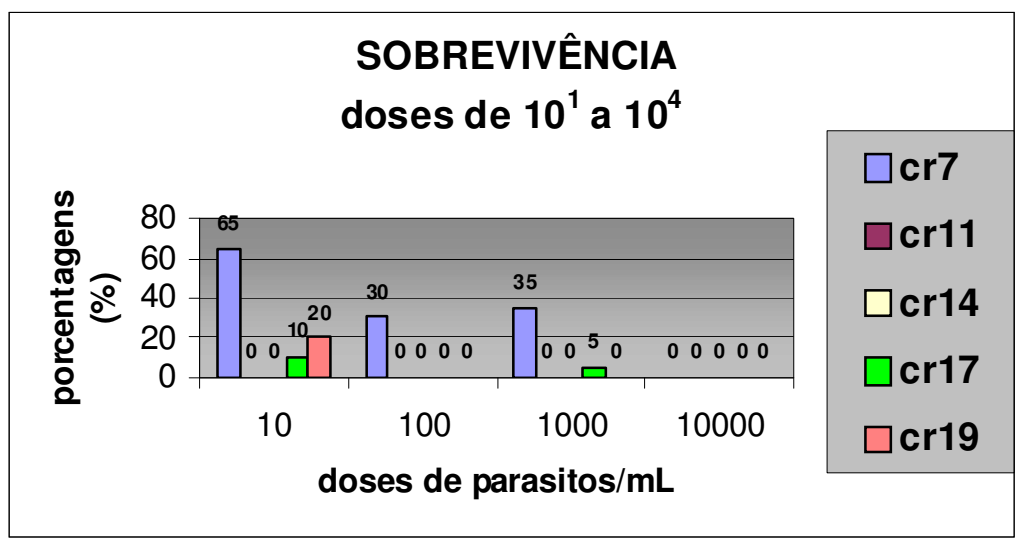

FIGURA 20: Porcentagem de sobrevivência das linhagens consômicas CSs7, CSs11, CSs14, CSs17 e CS19 nas doses de 10, 100, 1000 e 10000 tripomastigotas de T. cruzi.

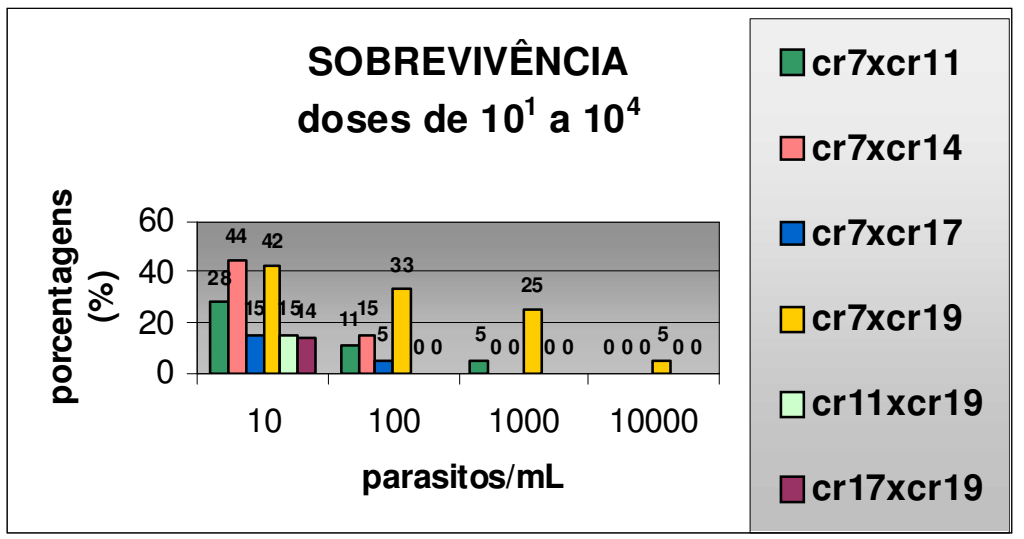

FIGURA 21: Porcentagem de sobrevivência das linhagens recombinantes consômicas de primeira geração $(7 \times 11,7 \times 14,7 \times 17,7 \times 19,11 \times 19$ e 17x19) nas doses de 10, 100, 1000 e 10000 tripomastigotas de T. cruz.

As linhagens consômicas dos cromossomos 11 e 14 e as linhagens dos cruzamentos $11 \times 14,11 \times 17,14 \times 17$ e 14×19 não apresentaram resistência para nenhuma dose.

O gráfico da figura 22 abaixo apresenta diferenças em porcentagens de sobrevivência entre machos e fêmeas, considerando a dose de $10^{1}$ tanto para as linhagens consômicas quanto para as linhagens derivadas dos cruzamentos. Esta dose foi escolhida porque é comum a todos os animais que sobreviveram: 


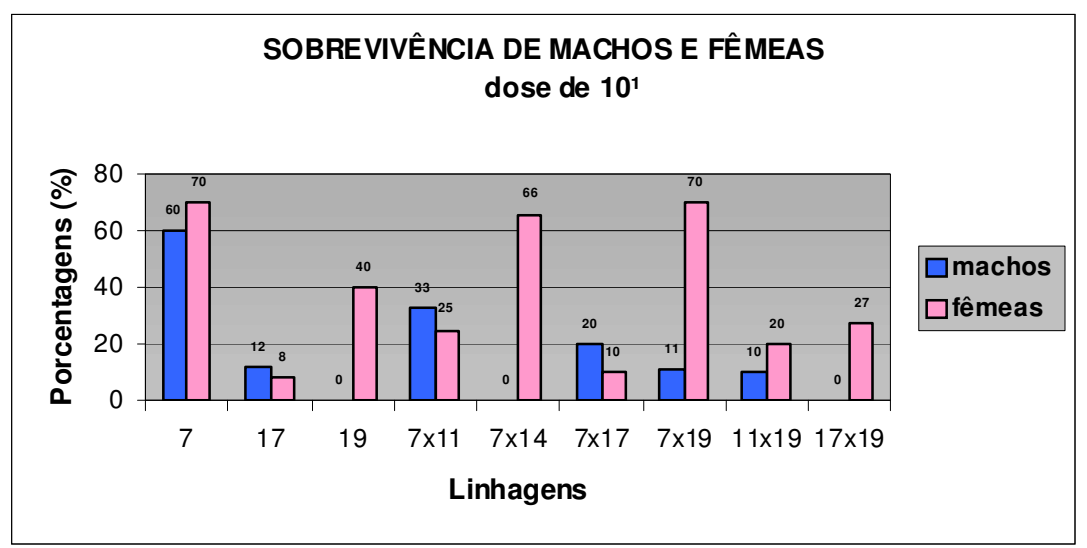

FIGURA 22: Porcentagem de sobrevivência comparando machos e fêmeas infectados com $10^{1}$ tripomastigotas de $T$. cruzi para todas as linhagens que apresentaram sobrevivência, sendo três linhagens consômicas CSs7, CSc17 e CSs19 e seis linhagens recombinantes consômicas de primeira geração $7 \times 11$, $7 \times 14,7 \times 17,7 \times 19,11 \times 19$ e $17 \times 19$. 


\section{DISCUSSÃO}

Segundo os Centers for Disease Control and Prevention e World Health Organization, existem atualmente, entre 8 a 11 milhões de pessoas infectadas com a Doença de Chagas e outras 25 milhões expostas ao risco. Entretanto, o mal de Chagas é ainda uma doença negligenciada, carecendo de investimentos para a fiscalização, prevenção, tratamento e estímulo para a investigação científica (CDC, $2009^{14}, \mathrm{WHO}, 2010^{1}$; Dias et al., 2002).

Devido à ausência de vacinas ou tratamento específico em larga escala, a principal estratégia de controle tem sido a prevenção da transmissão pelo vetor e o controle da transfusão sangüínea (Goldenberg \& Krieger, 1997; Dias et.al., 2002).

Embora as doenças parasitárias muitas vezes não matem de imediato, algumas comprometem significativamente a saúde dos doentes, interferindo em sua qualidade de vida e na sua capacidade de trabalho (Kropf et al., 2003).

Apesar de serem muitas as informações originadas com a investigação clínica em humanos, a maior parte dos conhecimentos da doença advém do uso de camundongos. Existem atualmente mais de 1500 linhagens deste modelo, muitas delas com características únicas, (Guénet \& Bonhomme, 2003), contudo, as linhagens isogênicas são, em geral, a primeira escolha em programas de investigação genética, uma vez que, por apresentarem uma homozigose em cerca de $99 \%$ dos alelos, respondem de forma homogênea, oferecendo resultados universais e reprodutivos (Beck et al., 2000; Magalhães, 2009; Massironi, 2009).

Não obstante estas vantagens, tanto o padrão sanitário como o genético dos modelos são essenciais, porquanto eliminam a participação de contaminantes nos ensaios, reduzindo fatores de interferência. Este fato é ainda mais importante quando o trabalho envolve a participação do genoma, pois a contaminação genética em muitas das vezes é silenciosa (Godard \& Guénet, 1999; Ko \& De Luca, 2009).

Por esta razão, no presente trabalho, primeiramente foi assegurada a qualidade genética dos animais, descartando contaminantes genéticos que inviabilizassem o seu uso.

\footnotetext{
${ }^{14}$ http://www.cdc.gov/chagas/
} 
Com o uso de microssatélites observou-se que as linhagens C57BL/6/Unib e A/JUnib não apresentavam contaminações, bem como o polimorfismo entre elas estava preservado, validando-as para uso na produção das linhagens consômicas.

Empregando um protocolo descrito por Demant \& Hart (1986), com algumas adaptações, foram produzidas 5 linhagens consômicas para os cromossomos 7, 11, 14, 17 e 19, que haviam sido descritos anteriormente por Passos et al. (2003), como importantes no controle da doença de Chagas experimental causada pela cepa $Y$ do Trypanosoma cruzi.

Segundo Nadeau et al. (2000) os modelos consômicos, também denominados por eles CSSs (chromosome substitution strain) ou linhagem com cromossomo substituído são úteis para dissecar traços complexos, oferencendo vantagens sobre outros modelos, tais como os recombinantes isogênicos ou recombinantes congênicos, na contribuição do genoma do doador em cromossomos individuais, uma vez que o padrão de diferenças fenotípicas observadas pode revelar a localização de QTLs, enquanto que nos outros modelos este padrão se apresenta em subconjuntos aleatórios e sobrepostos, e não separados, e portanto, a localização de QTLs não pode ser diretamente inferida pelos fenótipos.

Em 2004, Singer et al. demonstraram a construção de um painel completo contendo 22 linhagens consômicas, cada qual carregando um cromossomo substituído da linhagem doadora. A avaliação de 53 traços genéticos, 24 em fêmeas e 29 em machos revelaram a evidência de 150 QTLs relatados para níveis de esteróis, obesidade induzida por dieta, ansiedade e níveis de aminoácidos.

Pela metodologia empregada, séries alternadas de intercross e backcross fixaram o genoma da linhagem isogênica parental de fenótipo susceptível em todos os cromossomos, exceto para aquele de interesse, que, neste caso, em razão da seleção dirigida com marcadores moleculares de DNA, é do padrão resistente.

Os marcadores moleculares utilizados na genotipagem, para direcionar os acasalamentos, foram selecionados com intervalos de no máximo 14 centimorgans, ao longo de todos os cinco cromossomos (Tab. 2), exceto entre os marcadores D19mit119 (27,5 cM) e D19mit70 (51cM), onde a diferença foi de 
23,5 cM. Neste intervalo não foram encontrados outros marcadores polimórficos entre as duas linhagens parentais.

Durante as gerações de acasalamentos foram observadas algumas diferenças na reprodução entre as linhagens, o que demandou dificuldades e atrasos na obtenção das linhagens.

Um exemplo é a linhagem consômica para o cromossomo 17, a qual apresentou, a partir no terceiro backcross problemas na derivação, provavelmente por fatores genéticos. As fêmeas reprodutoras mantinham os intervalos entre gestações e números de filhotes comparáveis às outras linhagens, porém algumas morriam no momento do parto. Na maioria das vezes estas fêmeas não conseguiam parir todos os filhotes e assim toda a ninhada era perdida.

Nestes casos, foram necessários selecionar novas fêmeas reprodutoras, - que demandou cerca de quatro a seis meses desde a genotipagem, acasalamento e reprodução para continuidade do grupo.

Por esta e outras dificuldades encontradas durante os acasalamentos para a produção das linhagens, sempre foram mantidos vários casais de cada grupo. Para assegurar a produção de animais necessários na formação de cada geração, os antecedentes foram mantidos acasalados até o momento em que seus descendentes, previamente selecionados e já acasalados estivessem reproduzindo normalmente. Não houve problemas de reprodução após a obtenção dos consômicos, quando alguns camundongos de cada grupo foram acasalados para expansão.

O grande número de casais necessários para a produção das linhagens, exigiram infra-estrutura e mão de obra disponíveis, representando também dificuldades durante o presente trabalho, uma vez que o espaço destinado era limitado, portanto a expansão dos grupos limitava-se ao número de gaiolas e estantes disponíveis. Além do que o volume de trabalho distribuído em tarefas como, manejo dos animais, seleção por genotipagem, manutenção in vivo de $T$. cruzi, manutenção de registros e experimentos com infecção foram quase que individualmente realizados.

O uso acentuado de camundongos na investigação da doença de Chagas demonstrou que, na infecção experimental, existe um comportamento diferente entre as linhagens isogênicas que deriva da constituição genética do modelo. 
Dados da literatura informam que, enquanto algumas linhagens morrem ainda na fase aguda da doença, e com baixas doses de parasitas injetados i. p., outras controlam a infecção, passando para uma fase crônica, com todos os indivíduos sobrevivendo (Trischmann \& Bloom, 1982, Trischmann, 1983; Passos et al., 2003; Pontes-de-Carvalho et al., 2002; Graefe et al., 2003, 2006; Andersson et al., 2003; Di Marco et al., 2003).

Desta forma, os resultados observados no teste de infecção realizado com as linhagens C57BL/6/Unib e A/JUnib corroboraram a literatura, onde os animais destas linhagens apresentaram respectivamente os fenótipos resistente e susceptível, e os indivíduos que sobreviveram mais do que 30 dias foram considerados resistentes (Passos et al., 2003; Wrightsman et al., 1982, 1984).

Uma vez assegurada a diferença no comportamento das linhagens isogênicas parentais, que serviriam de controle da infecção, foram iniciados os experimentos com as linhagens consômicas, e os resultados obtidos com a infecção experimental com o $T$. cruzi nas doses de $10^{1}, 10^{2}, 10^{3}$ e $10^{4}$, demonstraram haver uma participação dos cromossomos 7 , com sobrevivência até a dose de $10^{3}$ parasitos, e, 17 e 19, com sobrevivência até as doses de $10^{2}$ e $10^{1}$, respectivamente de parasitos inoculados i.p. (Tab. 6).

Além disso, a comparação com os grupos parentais que serviram de controle revela que estes indivíduos são mais resistentes que o parental susceptível (65\% contra $5 \%$ para o cromossomo $7,10 \%$ contra $5 \%$ para o 17 e $20 \%$ contra $5 \%$ para o 19), corroborando os achados de Passos et al. (2003), que demonstram a importância destes cromossomos para sobrevivência do hospedeiro (Tab.7). Por outro lado, os animais consômicos para os cromossomos 11 e 14 não sobreviveram, provavelmente pelo fato da doença de Chagas ser uma doença multifatorial de trato complexo, geneticamente regulada por diferentes locos de caracteres quantitativos (QTL), que podem ter sido dissociados com 0 esquema adotado nos acasalamentos, interferindo tanto na regulação como na expressão diferencial dos genes (Trischmann \& Bloom, 1982; Kemp et al., 1997).

Este aspecto fica mais evidenciado quando analisamos a participação do cromossomo 7, isoladamente, no controle da infecção. Os resultados demonstram que este cromossomo assume um papel principal na sobrevivência e deve, por esta razão, regular e ser regulado pela expressão de genes de outros cromossomos, não avaliados neste trabalho. 
No cromossomo 7 encontram-se alguns genes, os quais podem ter grande influência no fenômeno da resistência à doença de Chagas, como é o caso do gene Fadd, localizado a 70cM (centiMorgans) e associado com a proteína Fas, do domínio de morte. Esta proteína atua como uma ponte ou molécula adaptadora, que interage com várias células receptoras de superfície, mediando sinais de toxicidade induzida por células apoptóticas. Estudos em camundongos Knockouts sugerem a sua importância no desenvolvimento inicial das células T. (Jackson Laboratory, 2010 ${ }^{15}$; NCBI, $2010^{16}$ ).

Outro gene do cromossomo 7, potencialmente envolvido na resistência e localizado a 61cM é o Mapk3, cuja proteína codificada atua como reguladora de uma variedade de sinais extracelulares, tais como a proliferação, diferenciação e progressão do ciclo celular (Jackson Laboratory, 2010 ${ }^{15}$; NCBI, $2010^{17}$ ).

Ainda no cromossomo 7 está o gene Tgfb1, localizado a 13,9 cM. É o fator de transformação de crescimento beta-1, que atua como um regulador de proteína (Jackson Laboratory, 2010 ${ }^{15}$ ).

O cromossomo 11, apesar de isoladamente não ter apresentado grande influência sobre a resistência, contém um gene que deve compor um importante QTL. Este gene é o Nos2 (nitric oxide synthase 2), localizado a 45,6 cM, o qual induz à síntese de NO (óxido nítrico), produzido pelos macrófagos, e de grande importância na resposta Th-1 do sistema imune (Gazzinelli et al., 1992; Vespa et al., 1994; Cardillo et al., 1996; Jackson Laboratory, 2010 ${ }^{15}$ ).

Ainda no cromossomo 11, a 25,9 cM localiza-se o gene IL12b (Interleucina 12 beta), que é o fator de maturação dos CLTs (linfócitos T citotóxicos), também chamados de células T CD8 citotóxicas, os quais provocam apoptose celular após estímulo por antígenos intracelulares apresentados pelo MHC classe I, pois reconhecem os peptídeos estranhos, que são transportados para a superfície celular. A função lítica desempenhada por estas células se dá pela liberação de dois tipos de citoxinas: as perforinas, que se polimerizam, formando poros na membrana da célula alvo, e as granenzimas, proteinases que penetram pelos poros formados, as quais atuam a nível citoplasmático e ativam a cascata enzimática de morte celular. Além disso, esta interleucina induz à uma

\footnotetext{
${ }^{15} \mathrm{http} / / /$ www.informatics.jax.org/searches/marker/

16,17 http://www.ncbi.nlm.nih.gov/sites/
} 
resposta imune do tipo Th1 ou celular, reconhecidamente importante na atividade antiparasitária (Jackson Laboratory, 2010 ${ }^{15}$; Universidade Fernando Pessoa, $2006^{18}$ ). Outra molécula importante expressa por um gene deste cromossomo, é a IL3 na posição de 32,1cM (interleucina 3) um fator estimulador de células mielóides que pode participar na sobrevivência dos animais, conferindo a estes uma maior higidez (Jackson Laboratory, 2010 ${ }^{19}$ ).

Os estudos realizados com a associação entre os consômicos revelaram uma progênie com diferentes níveis de resistência. Os filhos de primeira geração dos acasalamentos realizados entre as linhagens consômicas e que foram inoculados com as doses de $10^{1}$ a $10^{4}$, apresentaram resultados diferentes para o cromossomo 7 (Tab. 8a e 8b).

Enquanto os filhos dos casais $7 \times 19$ produziram descendentes com uma sobrevivência de 42\%, 33\% e 25\% nas doses de $10^{1}, 10^{2}$ e $10^{3}$ respectivamente, os casais $7 \times 17$ proporcionaram $15 \%$ de resistência a seus descendentes na dose de $10^{1}$, um valor de sobrevivência superior ao parental isogênico de fenótipo susceptível que foi de 5\%, e que sugere uma regulação negativa do cromossomo 17 da linhagem susceptível, quando comparado com a influência do cromossomo 19 desta mesma linhagem. Já os filhos dos casais 7X11, variaram em 28\%; 11\% e 5\% para estas mesmas doses, sendo muito importante destacar que o cromossomo 14 isoladamente não controlou a infecção. Por outro lado, a associação entre os outros cromossomos, mesmo que isoladamente não tenham controlado a doença, também se mostrou favorável à resistência. Os casais $11 \times 19$ e 17X19, praticamente respondem com a mesma capacidade para controlar a infecção e, em ambos os casos, de uma maneira muito superior ao parental susceptível original (Tab. 8a e 8b).

Para o cromossomo 17, diversos autores indicaram o seu envolvimento na resistência de camundongos ao $T$. cruzi, através do lócus $\mathrm{H}-2$, importante gene do MHC (major histocompatibility complex), ainda que num mecanismo secundário, porém com a interação de outros genes (Trischmann, 1982; Powell \& Wassom,1993). Neste sentido, estes dados corroboram os resultados deste trabalho, onde o cromossomo 17 mostrou-se importante no controle da infecção.

\footnotetext{
${ }^{18} \mathrm{http}: / /$ imunologia.ufp.pt/Imuno_MED/

${ }^{19}$ http://www.informatics.jax.org/
} 
Além disso, no cromossomo 17 , na posição aproximada de $20 \mathrm{cM}$, encontra-se o gene TNF- $\alpha$ (tumor necrosis factor), o qual é citado como um indicador de um segundo sinal de estimulação para a produção de NO na atividade anti-T.cruzi, induzida pelos macrófagos ativados por INF- $\gamma$, mediando assim a função tripanocida. (Silva et al., 1992; Jackson Laboratory, 2010 ${ }^{15}$ ).

No cromossomo 19, está o gene FasLG, localizado a 23cM, que atua como um receptor do fator de necrose tumoral, membro da superfamília 6 . Este gene, juntamente com o Fadd, do cromossomo 7 é parte integrante do complexo de sinalização para indução de apoptose, o qual é ativado pela ligação do Fas/ ao Fas (Jackson Laboratory, 2010 ${ }^{15}$; NCBI, 201020).

Todos estes resultados, ainda que inéditos, sugerem um mecanismo poligênico de resistência ao $T$. cruzi, como os já observados também para outras doenças multifatoriais de trato complexo como o Lupus Eritematoso Sistêmico (Andrade et al., 1985; Morel et al., 1996), a malária (Fortin et al., 1997, 2002; Gundula et al., 2007), a tuberculose (Sánchez et al., 2003) e a resistência a protozoários como a Leishmania e T. congolense (Stevenson \& Lyanga, 1982; Clapcott et al., 2000; Roberts et al., 1999; Kemp, et al., 1997).

Clapcott et al. (2000) revelaram em seus estudos com o Trypanosoma congolense, que representa a principal causa de tripanosomíase na África, que a diferença na sobrevivência entre linhagens isogênicas de camundongos considerados resistentes (C57BL/6 J) ou susceptíveis (BALB/C) é relacionada a três QTLs.

Além disso, a análise genética de doenças complexas derivadas de um evento inicial de comportamento estocástico, somente pode ser realizada com modelos animais desenvolvidos para a investigação de doenças de trato complexo (Matesic et al., 1999).

Contudo, o genótipo do hospedeiro, ainda que fundamental, responde apenas por uma parte da resistência, uma vez que a sobrevivência dos animais varia também, em função da dose infectante. Por esta razão, no interesse de avaliar o comportamento das linhagens consômicas na fase aguda da infecção, foi observado o período necessário para o estabelecimento do pico de parasitemia, após a administração de diferentes inóculos.

\footnotetext{
${ }^{20}$ http://www.ncbi.nlm.nih.gov/Structure/cdd
} 
Nos testes realizados, não foram identificadas diferenças nos dias em que a infecção começou a ser constatada (Figuras 11 a 15). Todos os modelos apresentaram dias muito próximos para a mesma dose.

Entretanto, chamam a atenção os dados relacionados ao dia do pico da parasitemia, quando o número de parasitas circulantes denuncia o esforço do hospedeiro para controlar a infecção.

A linhagem consômica para o cromossomo 7 apresenta um pico por volta do $19^{\circ}$ dia após a infecção, com a dose de $10^{4}$, enquanto nas demais linhagens o pico com esta dose é por volta do $13^{\circ}$ dia após a infecção. Uma exceção é feita na linhagem consômica para o cromossomo 19, que apresenta um comportamento excepcional que se deve a uma falha técnica ou a uma instabilidade na regulação da resposta imune na fase aguda da doença de Chagas, que necessita ser aprofundada.

Alguns autores observaram em estudos de malária uma forte influência sexual no controle da doença, onde as fêmeas geralmente apresentaram maior resistência que os machos, segundo os autores, possivelmente por fatores hormonais (Modiano et al., 1996; Wunderlich et al., 1988).

Os dados apresentados no gráfico da figura 22 também revelaram uma porcentagem superior de sobrevivência de fêmeas na dose de $10^{1}$ tripomastigostas, corroborando a bibliografia, que descreve doenças onde há envolvimento do cromossomo $X$ na resistência, assim como fatores hormonais ou ainda a relação entre o cromossomo $\mathrm{Y}$ e o aumento da susceptibilidade a patógenos intracelulares, tais como o T. cruzi (Clapcott et al., 2000; Modiano et al., 1996; Wunderlich et al., 1988).

A estratégia de se empregar acasalamentos programados, entre linhagens isogênicas com fenótipos distintos já foi utilizada, em diferentes momentos, na investigação da resistência e susceptibilidade a patógenos (Mock et al., 1993, 1994; Graefe et al., 2003), bem como uso desta estratégia, consorciado a regiões em desequilíbrio na freqüência dos alelos oriundos de cada parental isogênico original (Prows \& Horner, 2002; Iraqi et al. 2000).

Nos estudos de tuberculose, o emprego da derivação de linhagens congênicas de camundongos, os quais carregam combinações genotípicas particulares também foram apontados como estratégia para melhorar as chances 
de isolamento de genes candidatos ao controle da infecção por Mycobacterium tuberculosis (Kramnik et al, 1988; Sánchez et al., 2003).

Deste modo, a estratégia adotada no presente trabalho, bem como os resultados descritos acima são inéditos e deverão contribuir para um maior entendimento do complexo mecanismo de resistência à fase aguda da Doença de Chagas. 


\section{CONCLUSÕES}




\section{CONCLUSÕES}

- Os resultados observados nos ensaios com as linhagens consômicas, empregadas neste trabalho, confirmaram a participação dos cromossomos $7,11,14,17$ e 19 na sobrevivência de camundongos infectados com a cepa Y do Trypanosoma cruzi;

- As linhagens consômicas desenvolvidas para os cromossomos 7 (CSs7), 11 (CSs11), 14 (CSs14), 17 (CSs17) e 19 (CSs19) representam novos modelos para o estudo da participação de cada um deles na resistência à cepa Y do Trypanosoma cruzi;

- Todas as linhagens consômicas produzidas apresentaram porcentagem de resistência superior àquela observada no parental de fenótipo susceptível (A/JUnib);

- O esquema de acasalamento utilizado na produção das linhagens consômicas, consorciado à seleção dirigida por marcadores moleculares de microsatélites, se mostrou eficiente, onde após seis gerações de backcross com a linhagem receptora, o cromossomo de interesse da linhagem doadora foi substituído pelo seu homólogo, na linhagem receptora;

- As linhagens recombinantes consômicas de primeira geração, produzidas a partir dos cruzamentos entre os consômicos, permitem o estudo dos efeitos na associação de regiões importantes para a resistência, presentes em diferentes QTLs (locos de caracteres quantitativos), atuando também como novos modelos para a investigação da resistência à cepa $Y$ do $T$. cruzi;

- O cromossomo 7 desempenha um papel principal para a sobrevivência de camundongos infectados com à cepa $Y$ do Trypanosoma cruzi, conforme observado com os resultados de infecção experimenta,l que apresentaram maior porcentagem de sobrevivência para a linhagem consômica do cromossomo 7 (CSs7), bem como para todas as combinações de linhagens recombinantes consômicas de primeira geração que envolveram este cromossomo;

- Os cromossomos 11 e 14, isoladamente não apresentaram influência na resistência, mas em associação ao cromossomo 7 produziram um efeito favorável à sobreviência dos animais; 
- Os cromossomos 17 e 19, isoladamente, mostraram controle da infecção para doses baixas, demonstrando sua importância no mecanismo de resistência dos camundongos à cepa $Y$ de $T$. cruzi. 


\section{REFERÊNCIAS BIBLIOGRÁFICAS}

ALIBERT, J.C.S.; SOUTO, J.T.; MARINO, A.P.M.P.; LANNES-VIEIRA, J.; TEIXEIRA, M.M.; FARBER, J.; GAZZINELLI, R.T.; SILVA, S.S. Modulation of Chemokine Production and Inflammatory Responses in Interferon-g-and Tumor Necrosis Factor-R1-Deficient Mice during Trypanosoma cruzi Infection. American Journal of Pathology. 158(4): 2001.

ALMEIDA, E. A.; RAMOS-JUNIOR A.N., CORREIA, D. C.; SHIKANAI-YASUDA M.A. Rede Brasileira de Atenção e Estudos na Co-infecção Trypanosoma cruziHIV e em outras condições de imunossupressão. Revista da Sociedade Brasileira de Medicina Tropical. 42(5):605-608, 2009.

ANDERSSON, J.; ENGLUND, P.; SUNNEMARK, D.; DAHLSTEDT, A.; WESTERBLAD, H.; NENNESMO, I.; ORN, A.; LUNDBERG, I.E. CBA/J mice infected with Trypanosoma cruzi: an experimental model for inflammatory myopathies. Muscle Nerve. 27(4): 442-8, 2003.

ANDRADE, S.G.C.M. \& FIGUEIRA, R.M. Caracterização morfobiológica e histopatológica de diferentes cepas do Trypanosoma cruzi. Gazeta Médica da Bahia. (70): 32-42, 1970.

ANDRADE, V.; BARRAL-NETTO, M.; ANDRADE, S.G. Patterns of resistance of inbred mice to Trypanosoma cruzi are determined by parasite strain.

Brazilian Journal of Medical and Biological Research 18 (4); p. 499-506, 1985.

ARAUJO, L.M.M.; RIBEIRO, O.G.; SIQUEIRA, M.; DE FRANCO, M.; STAROBINAS, N.; MASSA, S.; CABRERA, W.H.K.; MOUTON, D.; SEMAN, M.; IBAÑEZ, O.M. Innate resistance to infection by intracellular bacterial pathogens differs in mice selected for maximal or minimal acute inflammatory response. European Journal of Immunology. (28): 2913-2920, 1998.

AZAMBUJA \& GARCIA ${ }^{6}$. Hospedeiro invertebrado. Portal da Fundação Oswaldo Cruz. Disponível em: $<$ http://www.fiocruz.br/chagas/cgi/cgilua.exe/sys/start.htm?sid=11>. Acesso em 03 abr. 2010.

BARBOSA-LABELLO, R. Transmissão oral do Trypanosoma cruzi pela polpa de açaí em camundongos. Dissertação (mestrado) - Universidade Estadual de Campinas, Instituto de Biologia. Campinas, SP, 2010.

BHATIA, V.; SINHA, M.; LUXON, B.; GARG, N. Utility of the Trypanosoma cruzi sequence database for identification of potential vaccine candidates by in silico and in vitro screening. Infection and Immunity. 72(11):6245-54, 2004.

BECK, J.A.; LLOYD, S.; HAFEZPARASAT, M.; LENNON-PIERCE, M.; EPPIG, J.T.; FESTING, F.W.; FISCHER, M.C. Genealogies of inbred strains. Nature Genetics. (24): 23-25, 2000. 
BESTETTI, R.B.; MARTINS, C.A. \& CARDINALLI-NETO, A. Justice where justice is due: A posthumous Nobel Prize to Carlos Chagas (1879-1934), the discoverer of American Trypanosomiasis (Chagas. disease). International Journal of Cardiology. (134): 9-16, 2009.

BRAGA, L.M.G.M. Os 3 Rs. In: Lapchik, V.B.V., Mattaraia, V.G.M., Ko, G.M. Cuidados e Manejo de Animais de Laboratório. (3):29-36, 2009.

BRENER, Z. Therapeutic activity and criterion of cure in mice experimentally infected with Trypanosoma cruzi.

Revista do Instituto de Medicina Tropical. 4(6): 389-396, 1962.

BRENER, Z. A descoberta (homenagem aos 80 anos da descoberta da Doença de Chagas). Memórias do Instituto Oswaldo Cruz. (84): 1-6, suplemento II, 1989.

BRENER, Z.; ANDRADE, Z.; BARRAL-NETO. M (eds.). Trypanosoma cruzi e doença de Chagas, 2. ${ }^{a}$ edição. Rio de Janeiro: Guanabara Koogan Ed., 2000.

CAMANDAROBA, E.L.; PINHEIRO-LIMA C.M.; ANDRADE, S. Oral transmission of Chagas' disease: importance of Trypanosoma cruzi biodeme in the intragastric experimental infection. Revista do Instituto de Medicina Tropical de São Paulo; (44): 97-103, 2002.

CARDILLO, F.; VOLTARELLI, J.C.; REED, S.G.; SILVA, J.S. Regulation of Trypanosoma cruzi Infection in Mice by Gamma Interferon and interleukin 10: Role of NK Cells. Infection and Immunity. 64(1): 128-134, 1996.

CENTERS FOR DISEASE CONTROL AND PREVENTION- CDC ${ }^{14}$. Epidemiology \& Risk Factors. Chagas Disease. 2009. Disponível em: <http://www.cdc.gov/chagas/>. Acesso em 01 ago. 2010.

CLAPCOTT, S. J.; TEALE, A.J. \& KEMP, S.J. Evidence for genomic imprinting of the major QTL controlling susceptibility to trypanosomiasis in mice.

Parasite Immunology. (22): 259 $263,2000$.

CORSINI, A.C.; COSTA, M.G. ; OLIVEIRA, O.L.P.; CAMARGO, I.J.B. \& STELINI Jr., A. Susceptibility of inbred mice to Trypanosoma cruzi strain Y. Revista do Instituto de Medicina Tropical de São Paulo. (22):192-6, 1980.

COUPER, K. N.; BLOUNT, D.G.; RILEY, E.M. IL-10: The Master Regulator of Immunity to Infection. Journal of Immunology. (180): 5771-5777, 2008.

DAVISSON, M.T. \& TAFT, R.A. Strategies for managing an ever increasing mutant mouse repository. Brain Research.1091(1): 255-7, 2006.

DEMANT, P.; HART, A.A.M. Recombinante congenic strains-a new tool for analyzing genetic traits determined by more than one gene. Immunogenetics. (24): 416-422,1986. 
DIAS, J.C.P.; MACHADO, E.M.M.; FERNANDES, A.L.; VINHAES, M.C. Esboço geral e perspectivas da Doença de Chagas no Nordeste do Brasil. Caderno de Saúde Pública.16 (sup.2): S13-S34, 2000.

DIAS, J.C.P.; SILVEIRA, A.C.; SCHOFIELD, C.J. The impact of Chagas Disease Control in Latin America - A Review. Memórias do Instituto Oswaldo Cruz. 97(5): 603-612, 2002.

DIAS, J.C.P. Doença de Chagas e transfusão de sangue no Brasil: vigilância e desafios. Revista Brasileira de Hematologia e Hemoterapia. 28(2): 81-87, 2006.

DI MARCO, S.; MOISAN, J.; MARIE-LINDA, B.; SKAMENE, E.; RADZIOCH, D. Recombinant congenic strains of mice: a new tool for the genetic dissection of efficacy and toxicity of adjuvant. Vaccine. 21(9): 832-835, 2003.

DUFFY, T.; BISIO, M.; ALTCHEH, J.; BURGOS, J.M.; DIEZ, M.; LEVIN, M.J.; FAVALORO, R.R.; FREILIJ, H.; SCHIJMAN, A.G. Accurate Real-Time PCR Strategy for Monitoring Bloodstream Parasitic Loads in Chagas

Disease Patients. PLoS Neglected Tropical Diseases. 3(4): e419, 2009.

EKSI, S.; WASSOM, D.L.; POWELL, M.R. Host genetics and resistance to acute Trypanosoma cruzi infection in mice: profiles and compartmentalization of IL-2-, 4-, -5-, -10-, and IFN-gamma-producing cells. Journal of Parasitology. 82(1): $59-65,1996$.

HUERRE, M.R.; GOUNON, P. Inflammation: patterns and new concepts. Research in Immunology. (147): 417-34, 1996.

FAGUNDES, D.J.\& TAHA, M.O. Modelo animal de doença: critérios de escolha e espécies de animais de uso corrente. Acta Cirúrgica Brasileira. 19(1): 59-64. 2004.

FECHIO, C.J.; SOARES, A.M.V.C.; OLIVEIRA, S.L.; SARTORI, A. Experimental visceral leishmaniasis in high and low antibody - producer mice (selection IV-A). Revista da Sociedade Brasileira de Medicina Tropical. 32(3): 229-234, 1999.

FERREIRA, C. S., AMATO NETO, V., GAKIYA, E., BEZERRA, R.C. \& RODRÍGUES ALARCÓN, R.S. Microwave treatment of human milk to prevent transmission of Chagas Disease. Revista do Instituto de Medicina Tropical. São Paulo 45(1): 41-42, 2003.

FERREIRA, I.I.M. \& SILVA, T.P.T. Eliminação da transmissão da doença de Chagas pelo Triatoma infestans no Brasil: um fato histórico. CARTA AO EDITOR. Revista da Sociedade Brasileira de Medicina Tropical 39(5): 507-509, 2006. 
FIUZA, J.A.; F, R.T.; GOMES, J.A.S.; ROCHA, M.O.C.; CHAVES, A.T.; ARAÚJO, F.F.; FARES, R.C.G.; TEIXEIRA-CARVALHO, A.; MARTINS-FILHO, O.; CANÇADO, G.G.L.; CORREA-OLIVEIRA, R. Profile of Central and Effector Memory $T$ Cells in the Progression of Chronic Human Chagas Disease. PLOS Neglected Tropical Diseases. 3(9): 1-9, 2009.

FORTIN, A.; BELOUCHI, A.; TAM M.F.; CARDON, L.; SKAMENE, E.; STEVENSON, M.M.; GROS, P. Genetic control of blood parasitaemia in mouse malaria maps to chromsome 8 (letter). Nature Genetics. (17): 382-383,1997.

FORTIN, A.; DIEZ, E.; ROCHEFORT, D.; LAROCHE, L.; MALO, D.; ROULEAU, G.A.; GROS, P.; SKAMENE, E. Recombinant congenic strains derived from $\mathrm{A} / \mathrm{J}$ and C57B1/6J: a tool for genetic dissection of complex traits. Genomics. (74): 2135, 2001.

FORTIN, A.; STEVENSON, M. M.; GROS, P. Complex genetic control of susceptibility to malaria in mice. Genes and Immunology. (3): 177-186, 2002.

FRAJBLAT, M.; AMARAL, V.L. L.; RIVERA, E.A.B. Bem Estar em Animais de Laboratório. In: Rogerio Christofoletti e Alfeu Antônio Hausen Beck. (Org.). Ética, Ciência e Desenvolvimento. Itajaí: Editora da Universidade do Vale do Itajaí, 117-128, 2006.

FREITAS, V.L.T. Avaliação dos níveis de parasitemia por PCR em tempo real em pacientes com doença de Chagas crônica e pacientes com co-infecção HIVTrypanosoma cruzi, com e sem reativação da doença de Chagas. Tese (Doutorado). Faculdade de Medicina da Universidade de São Paulo, 2009.

GAZZINELLI, R.T.; OSWALD, I.P.; HIENY, S.; JAMES, S.L.; SHER, A. The microbicidal activity of interferon-g-treated macrophages against Trypanosoma cruzi involves an L-arginine-dependent, nitrogen oxide-mediated mechanism inhibitable by interleukin-10 and transforming growth factor-b. European Journal Immunology. (22): 2501-2506, 1992.

GODARD, A.L.B.; GUÉNET, J.L., Genética de camundongos: modelos animais de doenças humanas. Biotecnologia Ciência e Desenvolvimento. 2(9): 96-100, 1999.

GOLDENBERG, S.; KRIEGER, M.A. Doença de Chagas: Novas perspectivas no diagnóstico imunológico. Biotecnologia Ciência e Desenvolvimento. 1(1): 2627, 1997.

GONTIJO, E.D. \& SANTOS, S.E. ${ }^{7}$ Mecanismos principais e atípicos de transmissão da doença de Chagas. Portal da Fundação Oswaldo Cruz. Disponível

em: <http://www.fiocruz.br/chagas/cgi/cgilua.exe/sys/start.htm?sid=25>. Acesso em 03/04/2010. 
GRAEFE, S.E.B.; MEYER, B.S.; MÜLLER-MYHSOK, B.; RÜSCHENDORF, F.; DROSTEN, C.; LAUE, T.; STEEG, C.; NÜRNBERG, P \& FLEISHER, B. Murine susceptibility to Chagas' disease maps to chromosomes 5 and 17. Genes and Immunity. (4): 321- 325, 2003.

GRAEFE, S.E.B.; STRECHERT, T.; BUDDE, B.S.; NÜRNBERG, P.; STEEG, C.; MÜLLER-MYHSOK, B. \& FLEISCHER, B. Genes from Chagas Susceptibility Loci That Are Differentially Expressed in T. cruzi-Resistant Mice Are Candidates Accounting for Impaired Immunity.PLoS ONE.1(1): e57, 2006.

GUÉNET, J-L.; BONHOMME, F. Wild mice: an ever-increasing contribution to a popular mammalian model. Trends in Genetics.19(1): 24-31, 2003.

GUNDULA, M.; FORTIN, A.; PITARI, G.; MIFONG, T.; STEVENSON, M.M.; GROS, P. Complex genetic control of susceptibility to malaria: positional cloning of the Char9 locus. The Journal of Experimental Medicine. 204(3): 511-524, 2007.

IRAQI, F.; CLAPCOTT, S.J.; KUMARI, P.; HALEY, C.S.; KEMP, S.J.; TEALE, A.J. Fine mapping of trypanosomiasis resistance loci in murine advanced intercross lines. Mammalian Genome. 11(8): 645-8, 2000.

JACKSON LABORATORY ${ }^{8}$. C57BL/6J - Strain Information. Disponível: <http://jaxmice.jax.org/strain/000664.html>. Acesso em 13 mar. 2010.

JACKSON LABORATORY ${ }^{10}$. A/J - Strain Information. Disponível em: <http://jaxmice.jax.org/strain/000646.html>. Acesso em 13 mar. 2010.

JACKSON LABORATORY ${ }^{12}$. CBA/J - Strain Information. Disponível em: $<$ http://jaxmice.jax.org/strain/000656.html>. Acesso em 13 mar. 2010.

JACKSON LABORATORY' ${ }^{15}$ Disponível em: <http://www.informatics.jax.org/searches/marker/> . Acesso em 03 set. 2010.

JACKSON LABORATORY ${ }^{19}$. Disponível em:

$<$ http://www.informatics.jax.org/javawi2/servlet/WIFetch?page=markerDetail\&key= 10393>. Acesso em 09 dez. 2010.

JACKSON LABORATORYa . Leading the Search for Tomorrow's Cures. Hybrid Mice. JAX ${ }^{\circledR}$ Mice Catalog.(7):36, 2009.

JACKSON LABORATORY ${ }^{\mathrm{b}}$. Leading the Search for Tomorrow's Cures. Congenic Strains. JAX ${ }^{\circledR}$ Mice Catalog.(8):42, 2009.

JACKSON LABORATORY. Leading the Search for Tomorrow's Cures. Recombinant Congenic Strains. JAX ${ }^{\circledast}$ Mice Catalog.(10):475, 2009. 
JACKSON LABORATORY'. Leading the Search for Tomorrow's Cures. Consomic Strains. JAX ${ }^{\circledR}$ Mice Catalog.(10):475, 2009.

KEMP, S.J.; IRAQI, F.; DARVASI, A.; SOLLER, M.; TEALE, A.J. Localization of genes controlling resistance to trypanosomiasis in mice. Nature Genetics. 16(2): 194-6, 1997.

KO, G.M. \& DE LUCA, R.R. Camundongo. In: Lapchik, V.B.V., Mattaraia, V.G.M., Ko, G.M. Cuidados e Manejo de Animais de Laboratório. (12):137-165, 2009.

KONDO, Y.; MORI, M.; KURAMOTO, T.; YAMADA, J.; BECKMANN, J.S.; CHAZZOTTES, D.S.; MONTAGUTELLI, X.; GUÉNET, J-L.; SERIKAWA, T. DNA segments mapped by reciprocal use of micro satellite primers between mouse and rat. Mammalian genome. (4): 571-576, 1993.

KRAMNIK, I.; DEMANT, P.; BLOOM, B.R.. Susceptibility to tuberculosis as a complex genetic trait: analysis using recombinant congenic strains of mice. Novartis Foundation Symposium. 217:120-131, 1998.

KROPF, S.P.; AZEVEDO, N.; FERREIRA, L.O. Biomedical Research and Public Health in Brazil: The Case of Chagas' Disease (1909-50). Social History of Medicine. 16: (1) 111-129, 2003.

LANNES-VIEIRA, J.A F $^{5}$ Doença. Portal da Fundação Oswaldo Cruz. Disponível em: <http://www.fiocruz.br/chagas/cgi/cgilua.exe/sys/start.htm?sid=25>.

Acesso em 03 abr. 2010.

LAPCHIK, V.B.V. \& MATTARAIA, V.G.M. Finalização Humanitária. In: Lapchik, V.B.V., Mattaraia, V.G.M., Ko, G.M. Cuidados e Manejo de Animais de Laboratório. (38):603-615, 2009.

LEWINSOHN, R. Do caldo de cana ao suco de açaí (Parte I). Jornal da Unicamp, 2005.

LIPOLDOVÁ, M.; SVOBODOVÁ, M.; KRULOVÁ, M.; HAVELKOVÁ, H.; BADALOVÁ, J.; NOHÝNKOVÁ, E.; HOLÁN, V.; HART, A.A.M.; VOLF, P.; DEMANT, P. Susceptibility to Leishmania major infection in mice: multiple loci and heterogeneity of immunopathological phenotypes. Genes and Immunity. (1): 200206, 2000.

LUZ, Z.M.P. COUTINHO, M.G.; CANÇADO, J.R.; KRETTLI, A.U.I. Hemocultura: técnica sensível na detecção de Trypanosoma cruzi em pacientes chagásicos na fase crônica da doença de Chagas. Revista da Sociedade Brasileira de Medicina Tropical. (27):134-8,1994.

MAGALHÃES, L.E. Evolução da Ciência de Animais de Laboratório. In: Lapchik, V.B.V., Mattaraia, V.G.M., Ko, G.M. Cuidados e Manejo de Animais de Laboratório. (1): 3-9, 2009. 
MALO, D. \& SKAMENE, E. Genetic control of host resistance to infection. Trends in Genetics. (10): 365-371, 1994.

MARTIN, D.; TARLETON, R. Generation, specificity, and function of CD8+T cells in Trypanosoma cruzi infection. Immunological Reviews. (201): 304-17, 2004.

MASSIRONI, S.M.G. Padrão Genético. In: Lapchik, V.B.V., Mattaraia, V.G.M., Ko, G.M. Cuidados e Manejo de Animais de Laboratório. (25):385-398, 2009.

MATESIC, L.E.; DE MAIO, A.; REEVES, R.H. Mapping Lipopolysaccharide Response Loci in Mice Using Recombinant Inbred and Congenic Strains. Genomics. 62: 34-41, 1999.

MÉDICOS SEM FRONTEIRA - MSF ${ }^{3}$. Doença de Chagas: cem anos de negligência. Informativo MSF. Ano 12, no24, p.6, 2009. Disponível em:

<http://www.msf.org.br/Arquivos/Doc/Publicacoes/56.pdf>. Acesso em 25 ago. 2010.

MILES, M.A.; CEDILLOS, R.A.; POVOA, M.M.; DE SOUZA, A.A.; PRATA, A.; MACEDO, V. Do radically dissimilar Trypanosoma cruzi strains (zymodemes) cause Venezuelan and Brazilian forms of Chagas' disease? Lancet. 20;1(8234):1338-40, 1981.

MINISTÉRIO DA SAÚDE. Consenso Brasileiro em Doença de Chagas. Revista da Sociedade Brasileira de Medicina Tropical. 38(Supl. III):12-14, 2005.

MINISTÉRIO DA SAÚDE². Nota de Certificação Internacional de Eliminação da Transmissão da Doença, $2006 . \quad$ Disponível em: http://portal.saude.gov.br/portal/arquivos/pdf/nota_chagas0206.pdf. Acesso em 03 ago. 2010.

MOCK, B.; BLACKWELL, J.; HILGERS, J.; POTTER, M.; NACY, C. Genetic control of Leishmania major infection in congenic, recombinant inbred and F2 population of mice. European Journal of Immunogenetics. 20(5): 335-348, 1993.

MOCK, B.A.; HOLIDAY, D.L.; CERRETI, D.P.; DARNELL, S.C.; O'BRIEN, A.D.; POTTER, M. Construction of a series of congenic mice with recombinant chromosome 1 regions surrounding the genetic loci for resistance to intracellular parasites (Ity, Lsh, and Bcg), DNA repairs responses (Rep-1), and the cytoskeletal protein vinilin (Vil). Infection and Immunity. 62(1): 325-8, 1994.

MODIANO, D.; PETRARCA, V.; SIRIMA, B.S. Different response to Plasmodium falciparum malaria in west African sympatric ethnic groups. Proceedings of the National Academy of Sciences - USA. (93): 13206-13211, 1996. 
MONCAYO, A. Chagas Disease: Current Epidemiological Trends after the Interruption of Vectorial and Transfusional Transmission in the Southern Cone Countries. Memórias do Instituto Oswaldo Cruz. Rio de Janeiro, 98(5): 577591, 2003.

MOREL, L.; YU, Y.; BLENMAN, K.R.; CALDWELL, R.A.; WAKELAND, E.K. Production of congenic mouse strains carrying genomic intervals containing SLEsusceptibility genes derived from the SLE-prone NZM2410 strain. Mammalian Genomes. (7): 335-339, 1996.

NADEAU, J. H., SINGER, J. B., MATIN, A. \& LANDER, E. S. Analysing complex genetic traits with chromosome substitution strains. Nature Genetics. (24): 221225, 2000.

NATIONAL CENTER FOR BIOTECNOLOGY INFORMATION - NCBI. ENTREZ GENE $^{17}$. Mapk3.Disponível em:

$<$ http://www.ncbi.nlm.nih.gov/sites/entrez?Db=gene\&Cmd=ShowDetailView\&Term ToSearch=5595>. Acesso em 08 dez. 2010.

NATIONAL CENTER FOR BIOTECNOLOGY INFORMATION - NCBI. ENTREZ GENE $^{16}$. Fadd. Disponível em:

$<$ http://www.ncbi.nlm.nih.gov/sites/entrez?Db=gene\&Cmd=ShowDetailView\&Term ToSearch=8772>. Acesso em 08 dez. 2010.

NATIONAL CENTER FOR BIOTECNOLOGY INFORMATION - NCBI. ENTREZ GENE $^{20}$. FasLG. Disponível em:

$<$ http://www.ncbi.nlm.nih.gov/sites/entrez?Db=gene\&Cmd=ShowDetailView\&Term ToSearch=8772>. Acesso em $08 \mathrm{dez} .2010$.

PAN AMERICAN HEALTH ORGANIZATION. CHAGAS DISEASE CONTROL PROJECT - PAHO: 2003 Annual Report. Disponível em: $<$ http://www.paho.org/English/ad/dpc/cd/dch-hon-informe-2003.htm>. Acesso em 02 ago. 2010.

PASSOS, L.A.C. Análise do determinismo genético da resistência de camundongos infectados experimentalmente com a cepa $\mathrm{Y}$ de Trypanosoma cruzi. Dissertação (doutorado) Universidade Estadual de Campinas, Instituto de Biologia. Campinas, SP, 2003.

PASSOS, L.A.C.; SAKURADA, J.K.; GUARALDO, A.M.A.; ORTIZ, S.C.B.C.; RANGEL, H.A.; GUENET, J.L. Chagas: Fenômeno da Resistência. Biotecnologia Ciência \& Desenvolvimento. (29): 26-29, 2003.

PELIZON, A.C.; DENADAI, B.; SCHIAVON, E.V.; MARTINS, D.R.; ZORZELLA, S.F.G.; SARTORI, A. Produção deficiente de citocinas Th1 em camundongos BALB/c jovens. Revista de Ciências Farmacêuticas Básica e Aplicada. 28(2): 171-176, 2007. 
PEREIRA, K.S.; SCHIMIDT, F.L.; GUARAIDO,A.M.A.; FRANCO, R.M.B.; DIAS, V.L.; PASSOS, L.A.C. Chagas' Disease as a Foodborne Illness-Review. Journal of Food Protection. 72(2): 441-446, 2009.

PEREIRA, K.S.; SCHMIDT, F.L.; BARBOSA, R.L.; GUARALDO, A.M.A.; FRANCO, R.M.B.; DIAS, V.L.; PASSOS, L.A.C. Transmission of Chagas Disease (American Trypanosomiasis) by Food. In Steve L. Taylor. Advances in Food and Nutrition Research. Burlington: Academic Press (59): 63-85, 2010.

PIRON, M.; FISA, R.; CASAMITJANA, N.; LÓPEZ-CHEJADE, P.; PUIG, L.; VERGÉS, M.; GASCÓN, J.; GÓMEZ I PRAT, J.; PORTÚS, M.; SAULEDA, S. Development of a real-time PCR assay for Trypanosoma cruzi detection in blood samples. Acta Tropica. (103): 195-200, 2007.

PONTES-DE-CARVALHO, L.; SANTANA, C.C.; SOARES M.B.P.; OLIVEIRA, G.G.S.; CUNHA-NETO, E.; RIBEIRO-DOS-SANTOS, R. Experimental Chronic Chagas' Disease Myocarditis is na Autoimmune Disease Preventable by Induction of Immunological Tolerance to Myocardial Antigens. Journal of Autoimmunity. (18): 131-138, 2002.

PORTAL DA SAÚDE ${ }^{4}$. Aspectos Epidemiológicos. Disponível em: $<$ http://portal.saude.gov.br/portal/saude/profissional/visualizar_texto.cfm?idtxt=314 54>. Acesso em 29 set. 2010.

PORTELA-LINDOSO, A.A.B. \& SHIKANAI-YASUDA, M.A. Doença de Chagas crônica: do xenodiagnóstico e hemocultura à reação em cadeia da polimerase. Revista de Saúde Pública. 37(1): 107-15, 2003.

POWELL, M.R. \& WASSOM, D.L. Host genetics and resistance to acute Trypanosoma cruzi infection in mice. I. Antibody isotype profiles. Parasite Immunology. 15(4): 215-21, 1993.

PROWS, D.R.; HORNER, M.L. Parental genetic contributions in the $A X B$ and $B X A$ recombinant inbred mouse strains. Mammalian Genome. (13): 127-133, 2002.

REED, S.G. In vivo administration of recombinant IFNgamma induces macrophage activation, and prevents acute disease, immune suppression, and death in experimental Trypanosoma cruzi infections. Journal of Immunology. (140): 4342, 1988.

ROBERTS, L.J.; BALDWIN, T.M.; CURTIS, J.M.; HANDMAN, E.; FOOTE, S.J. Resistance to Leishmania major is Linked to the H2 Region on Chromosome 17 and to Chromosome 9. Journal of Experimental Medicine. 185(9): 1705-1710, 1997. 
ROBERTS, L.J.; BALDWIN, T.M.; SPEED, T.P.; HANDMAN, E.; FOOTE S.J. Chromosomes $X$, 9, and the H2 locus interact epistatically to control Leishmania major infection. European Journal Immunology. 29(9): 3047-3050, 1999.

ROTHHAMMER, F., ALLISON, M. J., NÚÑEZ, L., STANDEN, V. A; ARRIAZA, B. Chagas' disease in pre-Columbian South America. American Journal of Physical Anthropology. (68): 495-498, 1985.

RUSSELL, W.M.S. \& BURCH, R.L. The Principles of Humane Experimental Technique. Methuen, London, 1959. Reprinted by UFAW, 1992.

SAMBROOK, J.; FRITSCH, E.F.; MANIATIS, T. Molecular Cloning: a laboratory manual. Cold Spring Harbor Laboratory, $2^{\text {nd }}$ ed. N.Y., Cold Spring Harbor Laboratory Press:1-59, 1989.

SANCHEZ-BURGOS, G.; MEZQUITA-VEGA, R.G.; ESCOBEDO-ORTEGON, J.; RAMIREZ-SIERRA, M.J.; ARJONA-TORRES, A.; OUAISSI, A., RODRIGUES, M.M.; DUMONTEIL, E. Comparative evaluation of therapeutic DNA vaccines against Trypanosoma cruzi in mice. FEMS Immunology \& Medical Microbiology, (50): 333-341, 2007.

SÁNCHEZ, F.; RADAEVA,T.V.; NIKONENKO, B.V.; PERSSON, A.S.; SENGUL, S.; SCHALLING, M.; SCHURR, E.; APT, A.S.; LAVEBRATT, C. Multigenic Control of Disease Severity after Virulent Mycobacterium tuberculosis Infection in Mice. Infection and Immunity. 71(1): 126-131, 2003.

SANT'ANNA, O.A.; MASSA, S.; MOUTON, D.; BOUTHILLIER, Y.; MEVEL, J.C.; IBAÑEZ, O.M.; VASSAO, R.; FRANCO, M.; BELLINATI, R.; SIQUEIRA, M.; BIOZZI, G. Salmonella typhimurium infection in high and low antibody responder mice:inverse correlation between antibody responsiveness and resistance to infection. FEMS (Federation of European Microbiological Societies) Microbiology Immunology. (47): 465-472, 1989.

SCHMUÑIS, G.A. A tripanossomíase americana e seu impacto na saúde pública das Américas. In: Brener Z AZ, Barral-Neto M., editor. Trypanosoma cruzi e Doença de Chagas. 2 ed. Rio de Janeiro: Guanabara Koogan, 2000.

SILVA, J.S.; TWARDZIK, D.; REED, S.G. Regulation of Trypanosoma cruzi infection in vitro and in vivo by transforming growth factor-beta. Journal of Experimental Medicine. (174): 539-545, 1991.

SILVA, J.S.; MORRISSEY, P.J.; GRABSTEIN, K.H.; MOHLER, K.M.; ANDERSON, D.; REED, S.G. Interleukin 10 and IFN-g regulation of experimental Trypanosoma cruzi infection. Journal of Experimental Medicine. (175): 169174, 1992. 
SINGER, J.B.; HILL, A.E.; BURRAGE, L.C.; OLSZENS, K.R.; SONG, J.; JUSTICE, M.; O'BRIEN, W.; CONTI, D.V.; WITTE, J.S.; LANDER, E.S.; NADEAU, J.H. Genetic Dissection of Complex Traits with Chromosome Substitution Strains of Mice. Genetics. (169): 855-862, 2005.

STEVENSON, M.M.; LYANGA, J.J. Murine malaria: genetic control of resistance to Plasmodium chabaudi. Infection and Immunity. 38(1): 80-88, 1982.

SECRETARIA DE VIGILÂNCIA EM SAÚDE DO MINISTÉRIO DA SAÚDE - SVS. Consenso Brasileiro em Doença de Chagas. Revista da Sociedade Brasileira de Medicina Tropical. 38 (Suplemento III): 2005.

SZAJNMAN, S.H.; RAVASCHINO, E.L.; DOCAMPO, R.; RODRIGUEZ, J.B.. Synthesis and biological evaluation of 1-amino-1,1-bisphosphonates derived from fatty acids against Trypanosoma cruzi targeting farnesyl pyrophosphate synthase. Bioorganic \& Medicinal Chemistry Letters. (15): 4685-4690, 2005

TEIXEIRA, R.L.; NASCIMENTO, R.J.; STURM, N.R. Evolution and pathology in Chagas disease - A Review. Memórias do Instituto Oswaldo Cruz. 101(5): 463 $-491,2006$.

TRISCHMANN,T.M. Trypanosoma cruzi: Early parasite proliferation and host resistance in inbred strains of mice. Experimental parasitology. 62(2): 194-201, 1986.

TRISCHMANN, T.M.; BLOOM, B.R. Genetics of Murine Resistance to Trypanosoma cruzi. Infection and Immunity. 35(2): 546-551, 1982.

TRISCHMANN, T.M. Non-antibody mediated control of parasitaemia in acute experimental Chagas disease. Journal of Immunology. (130): 1953-1957, 1983.

UNIVERSIDADE FERNANDO PESSOA - UFP ${ }^{18}$. Portugal, 2006. Linfócitos T. Grupo de Imunologia. Disponível em:

<http://imunologia.ufp.pt/Imuno_MED/TeoricasImunologia2006/Teorica03.ppt\#1>. Acesso em 07 dez. 2010.

VESPA, G.N.R.; CUNHA, F.Q.; SILVA, J.S. Nitric oxide is involved in control of Trypanosoma cruzi-induced parasitemia and directly kills the parasite in vitro. Infection and Immunity. (62): 5177-5182, 1994.

VON, A.; ZARAGOZA, E.; JONES, D.; RODRÍGUEZ-MORALES, A.J. \& FRANCOPAREDES, C. New insights into Chagas disease: a neglected disease in Latin America. Journal of Infection Developing Countries. 1(2): 99-111, 2007.

WEIL, M.M.; BROWN, B.W.; SERACHITOPOL, D.M. Genotype Selection to Rapidly Breed Congenic Strains. Genetics. (146): 1061-1069, 1997. 
WORLD HEALTH ORGANIZATION - WHO, 2007 WHO Consultation on International Biological Reference Preparations for Chagas Diagnostic Tests WHO. Geneva, 2-3 July 2007.

WORLD HEALTH ORGANIZATION - WHO. Chagas: One hundred years later. World Health Organization. 87(7): 491-492, 2009.

WORLD HEALTH ORGANIZATION - WHO'. Chagas disease (American trypanosomiasis). Fact sheet. N340, 2010. Disponível em: <http://www.who.int/mediacentre/factsheets/fs340/en/>. Acesso em 30 jul. 2010.

WRIGHTSMAN, R.; KRASSNER, S.M.; WATSON, J.D.; MANNING, J.E. Role of the H-2 Haplotype in Survival of Mice After Infection with Trypanosoma cruzi. Infection and Immunity. 44(2): 351-354, 1984.

WRIGHTSMAN R.; KRASSNER, S.; WATSON, J. Genetic Control of Responses to Trypanosoma cruzi in Mice: Multiple Genes Influencing Parasitemia and Survival. Infection and Immunity. 36(2): 637-644, 1982.

WUNDERLICH, F.; MOSSMANN, H.; HELWIG, M.; SCHILLINGER, G. Resistance to Plasmodium chabaudi in $\mathrm{B} 10$ mice: influence of the $\mathrm{H}-2$

complex and testosterone. Infection and Immunity. (56): 2400-2406, 1988. 


\section{ANEXOS}

\section{Anexo 1. Certificado da Comissão de Ética no uso de animais}

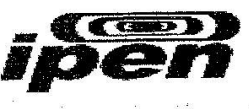

Parecer - Projeto $N^{\circ}$ 64/10/CEUA-IPEN/SP

Com base nos pareceres apresentados pelos relatores, o protocolo de pesquisa "ASPECTOS DA RESISTÉNCIA À INFECÇÃO EXPERIMENTAL COM Trypanosoma cruzi" de responsabilidade do pesquisador LUIZ AUGUSTO CORRÉA PASSOS foi considerado APROVADO.

Tendo em vista a legislação vigente, devem ser encaminhados, a este Comitê, relatórios anuais (parciais ou finais, dependendo da duração do projeto) referentes ao andamento da pesquisa. Após o término da pesquisa, uma cópia do trabalho deve ser encaminhada a este CEUA

São Paulo, 11 de junho de 2010

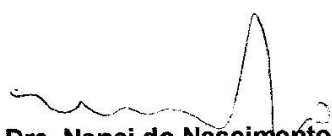

Profa. Dra. Nanci do Nascimento Coordenadora do CEUA-IPEN 


\section{Anexo 2. Extração de DNA}

\section{Extração de DNA por precipitação alcoólica a partir de orelha ou cauda.}

1- Retirar a orelha ou ponta da cauda do animal com aproximadamente 1,5 cm e transferir para um tubo identificado.

2- Depositar em cada tubo $700 \mu \mathrm{L}$ de Solução de Lise e $4 \mu \mathrm{L}$ de proteinase $\mathrm{K}$ a $20 \mathrm{mg} / \mathrm{mL}$.

3- Deixar em banho-maria até o dia seguinte a $37^{\circ} \mathrm{C}$.

4- Iniciar as lavagens:

Lavagem A: Adicionar em cada tubo $700 \mu \mathrm{L}$ de fenol saturado e deixar em agitação lenta por 10 minutos. Centrifugar a 9000 rpm por 5 minutos, recolher o sobrenadante e transferir para outro tubo.

Lavagem B: Adicionar ao DNA $700 \mu \mathrm{L}$ de clorofórmio e deixar em agitação lenta por 10 minutos. Centrifugar a 9000rpm por 5 minutos, recolher o sobrenadante e transferir para outro tubo.

Lavagem C: Acrescentar ao DNA $70 \mu \mathrm{L}$ (10\%) de acetato de sódio $3 \mathrm{M}$ e completar com álcool etílico absoluto PA. Homogeneizar até o DNA precipitar. Deixar em freezer a $-20^{\circ} \mathrm{C}$ por 20 minutos. Recolher a medusa com ponteira fina ou palito de madeira e depositá-la em outro tubo com cerca de $250 \mu \mathrm{L}$ de água deionizada autoclavada.

5- Deixar o tubo em estufa a 50ํำ por algumas horas e depois mantê-lo em geladeira a $4^{\circ} \mathrm{C}$.

\section{Preparo das soluções:}

\section{FENOL SATURADO:}

- $80 \mathrm{~mL}$ fenol

- $80 \mathrm{~mL}$ Tris $\mathrm{HCl} 0,5 \mathrm{M}-\mathrm{pH} 8,0$

\section{SOLUÇÃO DE LISE:}

- 5 mL SDS 20\%

- $5 \mathrm{Ml} \mathrm{NaCl} 5 \mathrm{M}$

- 10 mL Tris HCL $1 \mathrm{M}$ - pH 8,0

- EDTA 0,5M - pH 8,0 


\section{Anexo 3. PCR(Reação em Cadeia da Polimerase)}

1- Confeccionar o protocolo para as amostras.

2- Calcular o volume dos reagentes de acordo com a quantidade de amostras a serem testadas.

- Reação para 1 amostra, de $25 \mu \mathrm{L}$ de solução:

\begin{tabular}{|c|c|}
\hline $14,2 \mu \mathrm{L}$ & $\mathrm{H}_{2} \mathrm{O}$ \\
\hline $2,5 \mu \mathrm{L}$ & $\mathrm{Tp} 10 \mathrm{x}$ \\
\hline $2,0 \mu \mathrm{L}$ & $\mathrm{MgCl}_{2} 15 \mathrm{mM}$ \\
\hline $0,5 \mu \mathrm{L}$ & Dntps 4mM \\
\hline $0,35 \mu \mathrm{L}$ & Primer 1 \\
\hline $0,35 \mu \mathrm{L}$ & Primer 2 \\
\hline $0,1 \mu \mathrm{L}$ & Taq polimerase \\
\hline $5,0 \mu \mathrm{L}$ & DNA \\
\hline
\end{tabular}

3- Distribuir do DNA de cada amostra na placa, conforme protocolo.

4- Juntar ao DNA $20 \mu \mathrm{L}$ da reação, cobrir com uma gota de óleo mineral e levar ao Termociclador.

\section{Ciclo de Amplificação - Programa do Termociclador:}

$1^{\circ}$ - 94으/ 3 minutos.

$2^{\circ}-92^{\circ} \mathrm{C} / 1$ minuto.

$3^{\circ}$ - 55으 45 segundos.

$4^{\circ}$ - $72^{\circ} \mathrm{C} / 30$ segundos.

$5^{\circ}$ - Repetir a $2^{\circ}$ etapa por 49 vezes.

6 - $72^{\circ} \mathrm{C} / 5$ minutos.

$7^{\circ}$ - $25^{\circ} \mathrm{C} / 30$ segundos.

$8^{\circ}$ - Hold $4^{\circ} \mathrm{C}$. 


\section{Anexo 4. Eletroforese}

Fazer o mapa da eletroforese de acordo com o protocolo de PCR, planejando a disposição das amostras no gel.

A - Preparo do gel de agarose na concentração apropriada:

- Pesar a agarose

- Diluir em TBE 0,5X

- Acrescentar Brometo de Etídio, despejar na bandeja com os pentes e deixar polimerizar.

$B$ - Acrescentar às amostras aproximadamente 2,5 $\mu \mathrm{L}$ de Azul de Bromofenol. C - Mergulhar o gel em uma cuba com tampão TBE 0,5X. Aplicar no gel o DNA com Azul de Bromofenol e o padrão de peso molecular nos poçinhos, de acordo com seu mapa de eletroforese.

D - Deixar em corrida por 1hora, em cuba de eletroforese a $100 \mathrm{~V}$ e cerca de $130 \mathrm{~mA}$.

E - Levar ao fotodocumentador para o registro fotográfico.

F - Analisar os resultados.

\section{Preparo das soluções:}

\section{TBE 10X}

Tris - 216mg

Ácido Bórico - 110mg

EDTA 0,5M - pH8,0

qsp. $2000 \mathrm{~mL}$

\section{BROMOPHENOL BLUE C/ SACAROSE}

25mg - Bromophenol

$4 \mathrm{mg}$ - Sacarose

qsp. $10 \mathrm{~mL}$
GEL DE AGAROSE 4,2 \% $12 \mathrm{mg}$ - Agarose ultrapure 0,4 mg - Agarose tipo II diluir em $300 \mathrm{~mL}$ de TBE 0,5X

\section{BROMETO DE ETÍDEO}

100mg - Brometo de Etídeo

qsp. $10 \mathrm{~mL}$ 